Universidade de São Paulo

Faculdade de Economia, Administração e Contabilidade

Departamento de Economia

\title{
O DISCURSO CEPALINO: ENSAIO DE ANÁLISE RETÓRICA
}

Aluno: Cleofas Salviano Junior

Orientador: Profa. Dra. Ana Maria Afonso Ferreira Bianchi

São Paulo, 1993 
Reitor: Prof. Dr. Roberto Luiz Leal Lobo e Silva Filho

Diretor da Faculdade: Prof. Dr. Eduardo Pinheiro Gondim de Vasconcellos

Chefe do Departamento: Prof. Dr. Luiz Augusto de Queiroz Ablas 


\title{
Universidade de São Paulo \\ Faculdade de Economia, Administração e Contabilidade \\ Departamento de Economia
}

\section{O DISCURSO CEPALINO: \\ ENSAIO DE ANÁLISE RETÓRICA}

\begin{abstract}
Aluno: Cleofas Salviano Junior
Orientador: Profa. Dra. Ana Maria Afonso Ferreira Bianchi

Dissertação apresentada à Faculdade de Economia, Administração e Contabilidade da Universidade de São Paulo para obtenção do título de mestre em economia
\end{abstract}

São Paulo

Fevereiro, 1993 


\section{$\underline{\text { Agradecimentos }}$}

É de justiça registrar aqui o nome de minha orientadora, Ana Maria Bianchi, pela proverbial paciência com que esperou a longa gestação deste trabalho, pela presteza e eficiência com que respondeu a todas as (muitas) solicitações de revisão de capítulos que lhe fiz neste período, bem como pelo apoio constante.

Ao Prof. Eleutério Prado, meus agradecimentos pela mais que atenciosa carta recebida num momento de desânimo com a dissertação, e que é responsável, para o bem ou para o mal, por este trabalho ter chegado a seu termo.

Aos colegas Dante Aldrighi, Ramón Fernandez e Marcos Fernandes da Silva, agradeço a cuidadosa leitura e numerosas sugestões apresentadas ao capítulo I. Ao Prof. Eduardo Gianetti agradeço, igualmente, a cuidadosíssima leitura e numerosíssimas sugestões feitas a uma versão intermediária desta dissertação. A intensa crítica e troca de idéias desta forma efetuada só reforça minha crença na importância do debate e da argumentação e, por extensão, na importância de seu estudo.

Ressalvo, como de praxe, que as inevitáveis pequenas falhas e eventuais erros clamorosos são de minha inteira responsabilidade. 


\section{$\underline{\text { Resumo }}$}

Esta dissertação apresenta uma análise retórica do discurso da Comissão Econômica para a América Latina (CEPAL), tal como aparece em seu primeiro trabalho de relevo, o "Estudio Económico de América Latina - 1949". Tal análise baseia-se na teoria da argumentação proposta por Chaim Perelman e Lucie Olbrechts-Tyteca.

A análise propriamente dita consiste na identificação do público a que se dirige o discurso e intenta demonstrar como as premissas e os argumentos utilizados se adequam a seu público, com o fim de levá-lo a aceitar a tese primordial da CEPAL, qual seja, a necessidade de industrialização da América Latina. 


\begin{abstract}
$\underline{\text { Abstract }}$
This dissertation presents a rhetorical analysis of the discourse of the Economic Comission of Latin America (ECLA), as it appears in its first important work, the "Economic Survey of Latin America - 1949". Such analysis is based upon the theory of argumentation developed by Chaim Perelman and Lucie Olbrechts-Tyteca.

The analysis itself consists in the identification of the public the discourse is addressed to, and attempts to demonstrate how the premises and arguments used are framed according to its public trying to make it accept ECLAs most central proposition, i.e., the need for industrialization in Latin America.
\end{abstract}




\section{ÍNDICE}

$\begin{array}{ll}\text { Introdução } & 1\end{array}$

I- Retórica

I.1- Advertência

$\begin{array}{lr}\text { I.2- Perelman e a Retórica } & 8\end{array}$

$\begin{array}{ll}\text { I.3- Abordagens Alternativas } & 19\end{array}$

II- Contexto 23

$\begin{array}{ll}\text { II.1- Panorama ideológico } & 23\end{array}$

II.2- Antecedentes teóricos 25

II.3- Outros teóricos do desenvolvimento 27

$\begin{array}{lr}\text { II.4- Prebisch } & 29\end{array}$

II.5- A criação da CEPAL 30

II.6- Repercussão e críticas 33

II.7- A década de 1960

$\begin{array}{ll}\text { II.8- Observação } & 40\end{array}$

III- Texto 41

IV- Análise $\quad 50$

IV.1- As condições prévias da argumentação $\quad 50$

$\begin{array}{ll}\text { IV.2- Meta da persuasão } & 51\end{array}$

IV.3- O auditório 53

$\begin{array}{ll}\text { IV.4- Principais premissas } & 56\end{array}$

$\begin{array}{ll}\text { IV.5- A escolha dos dados } & 60\end{array}$

$\begin{array}{ll}\text { IV.6- Apresentação dos dados: presença } & 61\end{array}$

IV.7- Apresentação dos dados: outros aspectos 62

IV.8- Argumentos que fundam a estrutura do real: metáforas 66

IV.9- Técnicas de identidade completa: identificação entre conceitos 68

IV.10- Técnicas de identidade parcial: regra de justiça 69

$\begin{array}{ll}\text { IV.11- A divisão do todo em suas partes } & 70\end{array}$ 
IV.12- Argumentos baseados na estrutura do real: ligação de coexistência

IV.13- Interação entre argumentos

IV.14- A apreciação da força dos argumentos: mecanismos de atenuação

V- Conclusão 77

Referências Bibliográficas 


\section{Uma verdade não é verdade porque se a deseja; mas uma verdade não é descoberta se não se a deseja e porque se a deseja se a busca - Ortega y Gasset}

\section{Introdução}

O objetivo precípuo desta dissertação é fornecer subsídios para o estudo do processo de persuasão na ciência econômica em particular, e, num contexto mais amplo, da persuasão na ciência em geral. O texto cujas possibilidades persuasivas serão estudadas é o "Estudio Económico de América Latina - 1949", produzido pela Comissão Econômica para a América Latina (CEPAL), órgão das Nações Unidas.

É preciso justificar porque um economista se propõe fazer uma dissertação interdisciplinar, com todos os riscos inerentes a esta escolha. Fui atraído para este tema, a princípio, por um curso de lógica feito durante a graduação e pela leitura dos textos de Donald McCloskey (1983) e Pérsio Arida (1984) durante o período de créditos na pósgraduação. A cada nova leitura sobre a retórica crescia meu interesse pelo tema, e minha convicção de sua importância para a compreensão dos textos econômicos.

Fundamento tal convicção com a seguinte afirmação: o discurso econômico não é um raio em céu azul. Não é apenas um meio neutro para conduzir as idéias dos economistas, como pode fazer supor uma interpretação ingênua. Ele é, antes de tudo, um discurso. O que implica, seguindo o esquema já tradicional de Jakobson ${ }^{1}$, que existe um emissor, um receptor do discurso e uma mensagem a ser transmitida. Mais ainda, no caso do discurso persuasivo, que é claramente o caso do discurso científico, o emissor quer fazer aceitar pelo receptor a sua mensagem, transmitir-lhe sua visão dos fatos e seus valores ${ }^{2}$. É neste contexto que se coloca (melhor dizendo, se impõe) a questão da retórica.

É preciso identificar quais as formas utilizadas pelos economistas para alcançar a persuasão de seu público. Esta questão tem sido amplamente ignorada pela maioria dos economistas, quando não abertamente rejeitada. Tal situação apenas começou a mudar a partir do artigo pioneiro de McCloskey (1983) e de seu livro (1985), ambos abordando a retórica da economia.

\footnotetext{
${ }^{1}$ Cf. Dubois et alii (1970: 23).

${ }^{2}$ Koch (1987: 19) vai mais longe: "o homem [...] por meio do discurso, tenta influir sobre o comportamento do outro ou fazer com que compartilhe determinadas de suas opiniões. É por esta razão que se pode afirmar que o ato de argumentar [...] constitui o ato linguístico fundamental."
} 
Pelo dito até este ponto, apenas a consideração do discurso econômico como um discurso que visa a persuasão já justificaria o interesse pela retórica. Acresce que, segundo McCloskey (1985: 100) e Arida (1984: 42), a retórica dos textos econômicos é o determinante essencial da vitória ou derrota de teorias, na verdade o único determinante que resta, uma vez rejeitados (por inconclusivos, ou, no limite, destituídos de sentido) os critérios baseados na concordância com a experiência empírica. O conteúdo polêmico desta proposição é bastante atenuado se não tomarmos a palavra retórica no seu sentido vulgar, de manipulação discursiva com o fito de convencer, mas num sentido técnico, que envolve os meios pelos quais as crenças prévias do auditório são tornadas solidárias a outras, que o orador quer promover.

Nossa própria posição a respeito do teste empírico é a seguinte: este não se aplica diretamente ao corpo teórico, para corroborá-lo ou falseá-lo, mas o faz apenas através da argumentação, e é uma decisão do cientista acatar ou não suas implicações, rejeitar a experiência como falha ou irrelevante ou reformular a teoria com base nela. Portanto, a argumentação tem um papel central mesmo no que respeita à experiência empírica.

A abordagem ao problema da retórica proposta nesta dissertação é mais próxima à de McCloskey ${ }^{3}$ que à de Arida (v. seção I.3). A de McCloskey, no entanto, ao se concentrar em sua cruzada pró-retórica e anti-modernista, contenta-se com alinhavar exemplos do uso da retórica em textos variados, sem tentar integrá-los em uma teoria retórica. O fato de o presente estudo se concentrar em apenas um texto - o Estudio Económico de América Latina - 1949 - ${ }^{4}$ permite um exame mais detido, e, esperamos, mais profundo, de sua estratégia persuasiva. Tal exame mostra não meramente que há exemplos de procedimentos persuasivos no discurso econômico, mas, mais importante, que este é estruturado visando a persuasão. A presente abordagem é também menos ambiciosa que a de Arida, não pretendendo identificar as formas persuasivas comuns a todo o discurso econômico. Ao mesmo tempo, é mais inclusiva, já que considera as formas persuasivas nãocomuns, específicas de cada texto (embora fazendo parte do repertório de formas geral de nossa cultura) que evidentemente têm também finalidade persuasiva e força persuasiva.

Cabem algumas observações quanto à especificidade do texto objeto de nosso estudo, dentro do universo dos textos econômicos. Primeiramente, com relação a sua importância, sobre a qual permitimo-nos citar uma passagem de Gabriel Guzmán: "O papel transcendental desempenhado pela CEPAL na análise do processo de desenvolvimento latino-americano se acha acima de qualquer dúvida. Sua originalidade indiscutível provocou uma ampla polêmica, dentro e fora do continente, entre os economistas dedicados a problemas econômicos do mundo subdesenvolvido." (Guzmán 1976: 209).

\footnotetext{
${ }^{3}$ Para uma discussão da visão de McCloskey sobre o papel e a desejabilidade da retórica na ciência econômica, ver Aldrighi e Salviano Jr. (1990).

${ }^{4}$ Que daqui por diante, por brevidade, será chamado apenas de Estudio.
} 
Em segundo lugar, o Estudio, embora se apresente como uma avaliação objetiva da realidade econômica latino-americana, é um texto altamente engajado, que propõe e justifica decisões de política econômica. O mesmo não se poderia afirmar de outros textos econômicos eminentemente teóricos, o que não implica que estes últimos sejam menos retóricos. Afinal, tanto os discursos teóricos quanto os dirigidos diretamente à política econômica são discursos argumentativos, isto é, visam convencer aqueles a quem se dirigem. Apenas, os textos "políticos" mostram de forma mais clara os objetivos por eles visados, exigindo, portanto, menos da capacidade de interpretação do analista.

A escolha do Estudio como objeto de análise prende-se justamente a esta relativa facilidade de interpretação, bem como a sua evidente importância histórica na formação do pensamento econômico latino-americano, tema desenvolvido no capítulo II.

Para a análise retórica, apoiei-me extensivamente na teoria da argumentação proposta, num texto clássico, por Chaim Perelman e Lucie Olbrechts-Tyteca (1958) ${ }^{5}$, que catalogam uma enorme quantidade de procedimentos retóricos, acumulados desde a antiguidade clássica, nos mais variados campos onde se aventurou o discurso persuasivo.

O presente estudo tem a seguinte disposição: no capítulo I, apresenta-se uma discussão sobre a retórica, enfatizando sua utilidade na análise dos discursos irredutíveis a uma linguagem formalizada. A seguir expomos de forma concisa a teoria da argumentação de Perelman, apresentando os conceitos que serão posteriormente utilizados na análise do discurso cepalino. O capítulo termina com uma descrição sumária de outras vertentes da análise retórica.

O capítulo II traz informações sobre o contexto histórico no qual se insere a CEPAL. Procuramos detectar, através de menção à política econômica da época, o clima de opinião reinante na América Latina quanto à questão, essencial para a CEPAL, da industrialização e do protecionismo. Isto nos permite fundamentar a caracterização que fazemos, no capítulo IV, do auditório a que o discurso cepalino se dirige preferencialmente, e dos fins que visa atingir, através deste discurso. Identificamos também alguns antecedentes teóricos da CEPAL consignados na literatura e apresentamos outras correntes da teoria do desenvolvimento em voga na década de 1940. O capítulo contém ainda a repercussão dos primeiros textos produzidos pela instituição, bem como as principais críticas que sofreu.

O capítulo III descreve sucintamente os argumentos contidos na parte teórica, argumentativa, do Estudio. A segunda parte do texto é quase que exclusivamente descritiva, razão pela qual não a incluímos nesta dissertação. E o capítulo IV é destinado à análise retórica propriamente dita, identificando o público-alvo e os fins do discurso. Analisamos os

\footnotetext{
${ }^{5}$ Os dois autores daqui por diante serão designados, segundo o uso comum, apenas pelo nome de Perelman.
} 
diversos tipos de argumentos conducentes à realização destes fins e a forma como eles se articulam.

O último capítulo sumariza as conclusões alcançadas durante a discussão, enfatizando a necessidade e a fertilidade da análise retórica como forma de compreender os discursos científicos em seu contexto argumentativo. 


\section{I - RETÓRICA}

\section{I.1 - Advertência}

Faz-se necessária uma observação quanto ao caráter tentativo de nosso estudo. Propomos a análise retórica como uma abordagem fecunda à história do pensamento econômico, sem, contudo, pretender impô-la como um método incontestável ou mesmo privilegiado com relação aos outros. Sobretudo, há sempre um risco de má interpretação dos fins que o discurso visa atingir, o que evidentemente compromete a análise dos meios. $\mathrm{E}$ mesmo que os fins tenham sido corretamente identificados, o reconhecimento dos meios exige a interpretação do discurso, o preenchimento das lacunas da argumentação (v. Perelman 1958: 251). Tudo isto implica em que a análise retórica se apóia em hipóteses, cuja plausibilidade pode a qualquer momento ser posta em causa.

Por este motivo não cabe apresentar a análise retórica, por contraposição ao discurso retórico, como um elemento objetivo, capaz de eliminar a subjetividade própria do discurso a que se aplica. A análise retórica é, também ela, um discurso, realizado por um orador, que interpreta o discurso original de uma certa forma (entre outras possíveis) e se dirige a um determinado auditório. Também não cabe dizer que a análise retórica seja inútil, conduzindo a uma regressão infinita. Mesmo porque quem desconfia do discurso de forma absoluta tem suas possibilidades de conhecimento seriamente limitadas.

Entre a análise retórica objetiva e a inútil, escolhemos uma terceira via (in medio virtus!). Nela, a análise tem o papel de revelar a dimensão retórica do discurso, que é, para nós, como para Perelman, uma dimensão essencial. Revelar que o orador adapta seu discurso ao auditório ao qual se dirige; que ele induz o auditório a escolher entre alternativas quando não há um critério não-ambíguo de decisão; que o auditório, por seu turno, promove uma interação entre orador e discurso; que os argumentos também interagem entre si, e assim por diante, numa lista que, se não é infinita, é muito superior ao que poderia ser apresentado nesta dissertação.

\section{I.2 - Perelman e $\underline{\text { a retórica }}$}

Comecemos nossa exposição da teoria retórica de Perelman com uma observação sobre a recente revalorização da retórica, correlativa do reconhecimento das limitações do raciocínio apodítico, aquele baseado em premissas universalmente válidas, segundo regras lógicas universalmente aceitas: 
"Nos tempos modernos foi-se reduzindo cada vez mais a área atribuída aos discursos apodíticos, fundados na autoridade indiscutível da dedução lógica; e hoje somos levados a admitir a apodicidade unicamente para certos sistemas lógicos que deduzem de axiomas tidos como indiscutíveis. Todos os outros tipos de discurso, que outrora pertenciam à Lógica, à Filosofia, à Teologia etc., são hoje também reconhecidos como discursos suasórios, os quais tendem a sopesar argumentos não indiscutíveis e a inclinar o interlocutor para um determinado tipo de consenso, obtido com base não tanto na autoridade de uma Razão Absoluta, quanto na concorrência de elementos emocionais, de avaliações históricas, de móveis práticos." (Eco 1987: 73).

É neste processo de mudança intelectual que se insere o importante trabalho dos belgas Chaim Perelman e Lucie Olbrechts-Tyteca, que opõem ao racional, em sentido estrito, o razoável; à estreiteza do método, um conceito pluralista de verdade. Tais características permitem, por exemplo, a Kluback e Becker (1979), considerar sua filosofia "uma das mais significativas filosofias anti-dogmáticas do século vinte". Outras avaliações da obra de Perelman estão disponíveis em Jacques (1979), que discute as relações entre Aristóteles e Perelman, e ainda a possibilidade de redução da retórica à lógica, ponto também discutido por Gochet (1979). Barilli (1979) situa a Nova Retórica de Perelman no contexto da história intelectual recente, no plano da lógica e da epistemologia e no plano da linguística e da análise literária.

Perelman se aproxima do campo retórico a partir de suas reflexões sobre a prática e a teoria jurídicas, que não podem, na sua concepção, ser reduzidas a um conjunto de regras formais que guiariam a decisão judiciária. Isto porque é papel do juiz interpretar a lei para o caso específico, evitando suas ambiguidades e contradições, preenchendo suas lacunas, e - o que mais amplia sua liberdade de escolha - levando em conta o contexto. Por outro lado, a decisão judicial também não é arbitrária; ela é argumentada, fundamentada, e há toda uma metodologia jurídica que limita esta liberdade de escolha. Descartando estes dois extremos, a ambição de Perelman é a de descobrir como se pode entender o processo de decisão judicial como um processo racional, embora não formalizável. Deste ponto de partida, Perelman amplia suas preocupações, que passam a abranger todo o universo do discurso persuasivo, o qual, malgrado a crença generalizada no "modernismo" 6 inclui o discurso científico.

O autor em questão define a teoria da argumentação como "o estudo das técnicas discursivas que permitem provocar ou aumentar a adesão dos espíritos às teses que são submetidas à sua apreciação" (Perelman 1958: 5). É importante, de um lado, contrastar esta acepção com a noção comum da retórica, que, conquanto não difira muito da

\footnotetext{
${ }^{6}$ No sentido de McCloskey. Cf. McCloskey (1985: 3-11).
} 
concepção perelmaniana em seu aspecto positivo, carrega uma forte conotação negativa. Dizer de um discurso qualquer que ele é "mera retórica" é desqualificá-lo de maneira quase irremediável. É condená-lo aos domínios da "arte de enganar".

Um outro contraste, que, podemos supor, é o que determina o primeiro, se estabelece entre a concepção cartesiana da razão - que toma como paradigma o raciocínio de tipo geométrico, não admitindo senão as demonstrações necessárias - e o domínio do verossímil, do provável, do não necessário, visto como irracional e inadequado ao uso da ciência ${ }^{7}$. Segundo Perelman, a crença na validade desta dicotomia influenciou a filosofia ocidental dos últimos três séculos, tornando sem sentido o estudo dos meios de prova utilizados para obter adesão, e condenando, portanto, a retórica à decadência.

O esforço de Perelman é o de ampliar o âmbito do racional, incluindo nele os raciocínios que escapam a uma redução ao formal ${ }^{8}$. O foco de sua análise, como transparece em sua definição de teoria da argumentação, é o fenômeno da persuasão (ou adesão a uma tese), fortemente distinto do problema da verdade (ou validade de uma tese). Isto equivale a dizer que sua abordagem é pragmática, distinta da abordagem sintática e semântica que caracterizariam uma análise lógica do discurso ${ }^{9}$. A possibilidade e mesmo a necessidade da teoria da argumentação vêm de que há um meio termo entre o objetiva e indiscutivelmente válido e o absolutamente arbitrário, o subjetivo, a pura sugestão (v. Perelman 1958: 679 e Rorty 1979: 336). De fato, inclinamo-nos a pensar que este meio termo, que é o campo da argumentação ${ }^{10}$, é o relevante para a análise do discurso econômico, especialmente aquele voltado para a política econômica (como é o caso do Estudio), onde, para além dos objetivos propriamente teóricos, estão necessariamente presentes valores e interesses de toda espécie. Esta interligação, que, de forma infinitamente complexa, termina por conformar o discurso econômico, é, ao mesmo tempo, condição de possibilidade da análise retórica e fonte de dificuldades para os que se aventuram por este campo.

Uma questão que se coloca a todos os que abordam a retórica de uma perspectiva metodológica, de busca de critérios racionais de validação e de escolha entre teorias, é a da relação (se é que há alguma) entre a eficácia do discurso, sua persuasividade, de um lado, e sua validade, de outro.

A posição de Perelman frente a esta questão é de que, nos domínios do conhecimento estritamente formalizados, os critérios de validade são convencionados,

\footnotetext{
${ }^{7}$ A mesma distinção é retomada e criticada por Mirowski (1987: 70)

${ }^{8}$ Concepção bastante distinta da de Klamer, quando diz: "sem negar que haja alguma forma de racionalidade na discussão econômica, atribuo um papel significativo a elementos não racionais." (grifo nosso - Klamer 1988: 246)

${ }^{9}$ Empregamos aqui a tradicional classificação tripartite de Charles Morris, que reserva à Sintática o estudo das relações formais entre os signos; à Semântica o estudo das relações entre signos e coisas; e à Pragmática o estudo das relações entre os signos e seus usuários ou intérpretes.

${ }^{10}$ Utilizamos a expressão em sentido estrito, ou seja, excluindo a "argumentação" formal.
} 
estando, portanto, pelo menos provisoriamente fora de discussão. Assim, nestes domínios é possível distinguir rigorosamente o válido do não-válido. Nos demais domínios, que incluem, entre outros, o das ciências humanas, tais critérios são muito mais fluidos, sendo constantemente submetidos a debate e sujeitos a contra-argumentação. Eles dependem, fundamentalmente, da adesão do auditório. Portanto, se se toma a validade como dependendo de um critério objetivo (vale dizer, independente do debate), este conceito não se aplicaria às ciências humanas.

Resta-nos, então, a persuasividade. O que não nos obriga a tomar como legítimo, aceitável, todo e qualquer argumento persuasivo. De fato, o discurso não é persuasivo em si mesmo, mas para um determinado auditório. A garantia dos nossos raciocínios está, portanto, no discernimento dos auditórios. Ora, estes não se equivalem neste particular, podendo antes ser hierarquizados. McCloskey (1985: 512) confia na hierarquização dos auditórios por critérios acadêmicos, dando extrema importância à opinião dos "justamente influentes", os economistas reconhecidos, os detentores de prêmios Nobel. Tal proposição se expõe à crítica dirigida aos argumentos de autoridade, os quais, se tomados como demonstrações formais, são falácias. Já Perelman (1952: 38; 1958: 34) valoriza sobretudo o auditório universal. O argumento que convence, ou que poderia idealmente convencer a todos, independente das características e dos partis pris próprios a cada auditório, é o máximo a que podemos aspirar, e é o máximo que se pode pedir do orador ${ }^{11}$.

Cabe aqui uma observação. Se não há um critério objetivo pelo qual se possa aferir o progresso (ou involução) do conhecimento nos seus domínios não-formalizados, seríamos forçados a abrir mão da noção de progresso. A abordagem retórica cria uma saída para este dilema. O auditório, falível, emotivo, permeado por conflitos de opiniões, mas eminentemente racional, é o juiz último dos argumentos. Logo, o progresso da argumentação (vale dizer, o progresso das ciências humanas) é correlativo do progresso do auditório. E é através do debate que o auditório progride, se enriquece, torna-se crítico.

Uma segunda observação: dar a conhecer os processos intelectuais dos quais se servem os cientistas sociais é uma forma de contribuir para o progresso de seu auditório. Daí que Perelman, respondendo implicitamente a uma antiga acusação dirigida aos estudiosos da retórica, tenha observado: "Poderíamos dizer que a retórica, mais que formar os litigantes, deve formar o juiz" (Perelman 1952: 42).

Talvez estas considerações não satisfaçam ao metodólogo radical. Este não concede ao argumento meramente convincente qualquer papel no desenvolvimento da

\footnotetext{
${ }^{11} \mathrm{O}$ auditório universal não é único e inequívoco, mas aquele que o orador imagina ser o auditório universal. Logo, até neste ponto, em que Perelman nos apresenta uma regra para guiar a escolha dos argumentos, esta regra é, em última análise, dependente de uma decisão do orador. Sobre o papel do auditório universal em Perelman, v. Gochet (1979: 368-9).
} 
ciência, expurgando-o, portanto, de sua "reconstrução racional" da ciência ${ }^{12}$. Mas, mesmo de tal ponto de vista, a análise retórica encontra uma justificação: a persuasão é um fato inegável, assim como é inegável sua importância no processo social de transmissão do conhecimento. Portanto, os procedimentos tendentes a gerar a persuasão merecem ser estudados.

Com relação especificamente à análise retórica do discurso econômico, criticamos duas posições antagônicas, quais sejam as de McCloskey $(1983,1985)$ e Machlup (1967). Ambos se utilizam da análise retórica: o primeiro, para louvar as virtudes da main stream, e o segundo, para criticar seus desafetos teóricos.

A abordagem apologética de McCloskey ${ }^{13}$ tem o mérito de enfatizar a importância, para a ciência, da dimensão retórica do discurso. As técnicas e as interações retóricas entre orador e auditório são parte indissociável do procedimento normal da ciência. E tem o defeito de não ser passível de teste: tomado um discurso que obteve sucesso no debate econômico, sempre é possível apontar seus procedimentos retóricos mais salientes e atribuir-lhes o sucesso da teoria. O interessante seria ter elementos externos ao discurso sob exame, que permitissem conhecer as premissas e estruturas argumentativas favorecidas pelo auditório, e então confrontá-las com as do discurso efetivo ${ }^{14}$. Assim poder-se-ia ter evidências empíricas sobre a utilidade da retórica para o sucesso das teorias.

A abordagem hipercrítica de Machlup tampouco é passível de teste, pelo motivo oposto: ele não reconhece o caráter discursivo, argumentativo, e portanto retórico, da ciência em geral. Em vista disto, seu procedimento consiste em flagrar o uso de técnicas retóricas no discurso econômico, e contrapô-lo implicitamente a um discurso "neutro", "científico", livre de estratagemas. Ora, como dissemos há pouco, tal discurso imaculado simplesmente não existe fora dos domínios estritamente formalizados da ciência e, mesmo nestes, existe apenas enquanto as formalizações específicas não são postas em dúvida. Portanto é sempre possível observar os procedimentos retóricos ad hoc de um texto e assim desqualificá-lo.

Por outro lado, a abordagem de Machlup tem seu valor. Ela põe a nu a arbitrariedade de certos procedimentos retóricos, seu caráter forçado, que costumavam passar desapercebidos aos economistas. Esta é uma crítica legítima e que permitiria, se se pesquisasse todo o discurso econômico sob esta ótica, elevar o nível de exigência dos economistas quanto à qualidade de seus argumentos.

\footnotetext{
${ }^{12}$ V., por exemplo, Rosemberg (1988).

${ }^{13}$ Sobre esta interpretação de McCloskey, v. Mirowski (1987).

${ }^{14}$ Uma tentativa neste sentido foi feita por Mirowski (1987).
} 
Resumindo: tanto a abordagem apologética da retórica quanto a hipercrítica são unilaterais. Importa tirar delas um meio-termo, que reconheça o caráter argumentativo da ciência e procure, a partir deste reconhecimento, elevar os padrões discursivos.

Apresentamos a seguir, de forma muito sucinta, a estrutura da teoria da argumentação de Perelman, focalizando os conceitos que serão utilizados em nossa análise do discurso cepalino.

O fato posto em relevo por esta teoria é o de que o orador procura fazer aceitar uma determinada tese tornando-a solidária a premissas supostamente aceitas por seu auditório.

As premissas se dividem em duas categorias: as relativas ao real, que se caracterizam por se pretenderem válidas para o auditório universal, e as relativas ao preferível, que o orador supõe serem admitidas por auditórios específicos. A primeira categoria se subdivide em fatos, verdades e presunções. Os fatos diferem das verdades por se tratarem de objetos de acordo mais específicos, limitados, enquanto estas últimas são sistemas mais complexos, tais como teorias científicas e concepções filosóficas ou religiosas 15. As presunções são proposições que também gozam do acordo do auditório universal, porém de um acordo mais fraco, sujeito a ser fortalecido ou debilitado por uma argumentação posterior. Uma das presunções importantes é a relativa à existência de uma certa inércia psicológica, pela qual uma opinião adotada no passado pelo auditório, tende, coeteris paribus, a continuar sendo admitida, podendo por isto ser tomada como premissa pelo orador.

Já as premissas do preferível se subdividem em valores, $\underline{\text { hierarquias e lugares. }}$ Os valores, ao contrário da definição tradicional, que os identifica a atitudes frente ao real, são vistos por Perelman como objetos, seres ou ideais capazes de exercer sobre a ação do grupo uma influência determinada. As hierarquias afirmam a superioridade de certos seres ou valores abstratos sobre outros. Os lugares são premissas de ordem geral que permitem fundamentar valores e hierarquias. Em economia, por exemplo, a maximização (ou minimização) de variáveis se funda sobre um lugar da quantidade, o qual afirma que mais lucro, maior renda etc. são preferíveis a uma menor quantidade destas variáveis.

O exame das premissas permite uma classificação dos argumentos quanto ao auditório a que se dirigem. Todos os argumentos necessariamente se dirigem a algum auditório, quando mais não seja o auditório constituído pelo próprio orador. Esta a razão pela qual Perelman, divergindo do uso comum, os qualifica a todos de ad hominem. Uma distinção de particular importância é a que se faz entre argumento ad humanitatem e ad

\footnotetext{
${ }^{15}$ Salientamos que aqui, como no restante da dissertação, a expressão fatos deve ser entendida como afirmações que têm a concordância do auditório universal, e não como realidades objetivas (V. Perelman 1958: 89).
} 
hominem stricto sensu. O primeiro contém premissas que o orador julga aceitas pelo auditório universal, enquanto o segundo apela a crenças específicas de auditórios particulares.

Uma vez vistos os diversos tipos de premissas, cabe notar que elas não se impõem ao orador, mas são escolhidas por ele. Assim, todo orador dá presença, relevo, a certos dados, e negligencia ou mesmo escamoteia os dados que lhe são inúteis ou desfavoráveis, ou as premissas discutíveis. Esta parcialidade do orador não deve ser contraposta a uma teórica imparcialidade, que consistiria em apresentar todos os dados relevantes para a decisão do auditório: mesmo que o conjunto destes seja finito, não há um critério objetivo para determinar sua relevância. Não há como fugir da escolha.

Outra variável de escolha à disposição do orador é o grau de clareza das noções. A demonstração lógica exige uma linguagem unívoca; já as provas retóricas podem lançar mão da ambiguidade das noções, e é justamente por isto que tais provas não são impositivas, e precisam contar com uma interpretação favorável do auditório.

A presença dos dados é função não só de sua escolha, mas também de sua apresentação. A ênfase relativa, a repetição, a enumeração de detalhes, entre outras, são formas de conferir esta presença às premissas da argumentação, em especial às premissas que o orador julga terem maior aceitação no auditório.

Ainda com relação à forma de apresentação dos dados, há que fazer referência à escolha dos termos. Por meio desta escolha, pode-se demonstrar simplicidade, erudição, neutralidade, convicção, comunhão com o auditório, e explorar as conotações próprias de cada termo.

O exame das figuras retóricas não pode ficar de fora do estudo da forma do discurso. As figuras se caracterizam por terem uma estrutura e um uso discerníveis e que se afastam do uso comum da língua. Perelman particulariza a figura argumentativa, aquela que, gerando uma mudança de perspectiva, faz seu emprego parecer normal com relação à nova situação sugerida ${ }^{16}$. Daí seu interesse para a teoria da argumentação. A figura de estilo, ao contrário, tem um efeito restrito ao plano estético. Perelman não estuda as figuras por elas mesmas, mas apenas na medida em que elas sejam formas (codificadas ao longo do tempo) de manifestação de certos procedimentos retóricos. Por este motivo ele classifica as figuras retóricas segundo suas funções de sugerir uma escolha, aumentar a presença ou realizar a comunhão com o auditório ${ }^{17}$.

Uma última observação relativa à forma de apresentação dos dados: o orador tenta dar aos elementos sobre os quais ele se apóia o status mais elevado possível, e ao

\footnotetext{
${ }^{16}$ Um exemplo: A metáfora da "inércia inflacionária" flui com tal facilidade nas conversas entre economistas brasileiros que às vezes nem sequer se percebe seu caráter metafórico.

${ }^{17}$ Um estudo pormenorizado das figuras retóricas clássicas se encontra em Lausberg (1966).
} 
mesmo tempo tenta reduzir o status das premissas de seus adversários. Assim, por exemplo, ele procura atribuir aos sentimentos pessoais o status de valores (que são aceitos por determinado auditório), e aos valores o status de fatos (que têm a aceitação do auditório universal). Este último mecanismo é usual entre os economistas, que primam por tachar de irracionais os comportamentos que se regem por valores outros que não os seus.

Uma vez vistos os diversos aspectos da apresentação dos dados, Perelman trata dos argumentos propriamente ditos, classificando-os em procedimentos de ligação e $\underline{\text { de }}$ dissociação. Os primeiros visam estabelecer uma solidariedade entre elementos distintos, e

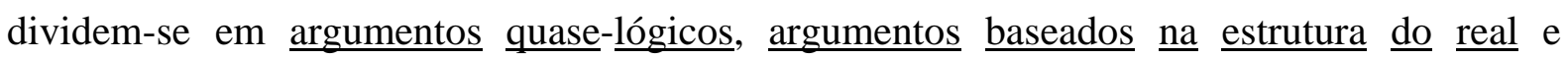

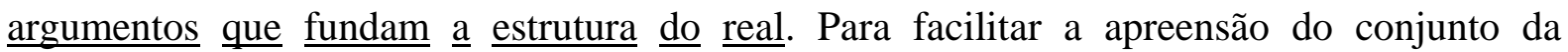
classificação de Perelman, apresentamos a tabela seguinte.

\section{TIPOLOGIA DAS TÉCNICAS ARGUMENTATIVAS}

1 - Procedimentos de ligação

\begin{tabular}{|c|c|c|}
\hline \multirow[b]{4}{*}{$\begin{array}{l}\text { argumentos } \\
\text { quase-lógicos }\end{array}$} & incompatibilidade & \\
\hline & $\begin{array}{l}\text { técnicas de identidade } \\
\text { completa }\end{array}$ & definiçõos \\
\hline & técnicas de identidade parcial & regra de justiça \\
\hline & $\begin{array}{l}\text { argumentos de transitividade } \\
\text { inclusão da parte no todo } \\
\text { divisão do todo em suas partes } \\
\text { argumentos de comparação } \\
\text { probabilidades }\end{array}$ & \\
\hline \multirow{3}{*}{$\begin{array}{l}\text { argumentos } \\
\text { baseados na } \\
\text { estrutura do real }\end{array}$} & ligações de sucessão & $\begin{array}{l}\text { argumentação pela causa } \\
\text { argumento pragmático }\end{array}$ \\
\hline & ligações de coexistência & $\begin{array}{l}\text { grupo-membros } \\
\text { pessoa-ato } \\
\text { essência-fenômeno }\end{array}$ \\
\hline & $\begin{array}{l}\text { argumentos relativos a } \\
\text { diferenças de grau e de ordem }\end{array}$ & \\
\hline \multirow[t]{2}{*}{$\begin{array}{l}\text { argumentos que } \\
\text { fundam a } \\
\text { estrutura do real }\end{array}$} & $\begin{array}{l}\text { fundamento pelo caso } \\
\text { particular }\end{array}$ & $\begin{array}{l}\text { exemplo } \\
\text { ilustração } \\
\text { modelo } \\
\end{array}$ \\
\hline & raciocínio por analogia & $\begin{array}{l}\text { analogia } \\
\text { metáfora }\end{array}$ \\
\hline
\end{tabular}

2 - procedimentos de dissociação

\begin{tabular}{|l|l|}
\hline ruptura de uma ligação & \\
\hline dissociação de noções & $\begin{array}{l}\text { aparência-realidade } \\
\text { artifício-real }\end{array}$ \\
\hline
\end{tabular}


Os argumentos quase-lógicos retiram seu poder de persuasão de sua semelhança com argumentos formais. Assim, por exemplo, na impossibilidade de achar uma contradição lógica no discurso de seu adversário - e é raro que haja uma contradição, fora do discurso estritamente formalizado ${ }^{18}$ - o orador procura achar nele incompatibilidades. Estas diferem da contradição pelo fato de dependerem seja da natureza das coisas, seja de uma decisão humana, isto é, de circunstâncias contingentes. A acusação de incompatibilidade, na medida em que depende de uma interpretação do orador, admite sempre uma contraargumentação. E finalmente, a incompatibilidade, em lugar de levar, como a contradição, ao absurdo, expõe ao ridículo aqueles a quem é imputada ${ }^{19}$. Motivo pelo qual uma das figuras que pode realizar este argumento quase-lógico é a ironia.

Exemplos de procedimentos quase-lógicos são as técnicas de identidade completa, tais como as definições, as classificações e o uso da indução. Estas técnicas visam reduzir os elementos aos quais se aplicam àquilo que eles têm em comum, negligenciando os aspectos que os diferenciam. Além das técnicas de identidade completa, há as de identidade parcial. Uma delas é a chamada regra de justiça, que "exige a aplicação de um tratamento idêntico a seres ou situações que são integrados a uma mesma categoria". Observe-se que a eficácia deste argumento depende de o auditório concordar com a classificação dos elementos diversos numa mesma categoria.

Outras técnicas listadas por Perelman: os argumentos de transitividade, que interpretam determinadas relações como sendo transitivas, como, por exemplo, as relações de implicação; a inclusão da parte no $\underline{\text { todo, }}$ que permite aplicar à parte qualquer qualificação válida para o todo, ou valorizar o todo em relação ao que é apenas parte dele; a divisão do

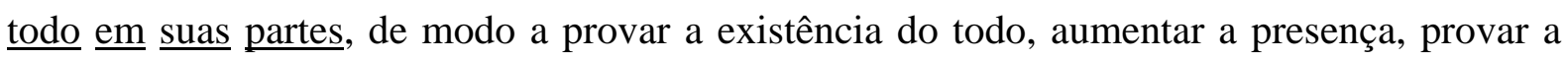
existência ou não-existência de uma das partes, produzir dilemas, etc.; os argumentos de comparação, aos quais subjaz uma idéia de medida, mesmo quando a qualidade de que se trata não é mensurável; os argumentos que utilizam probabilidades.

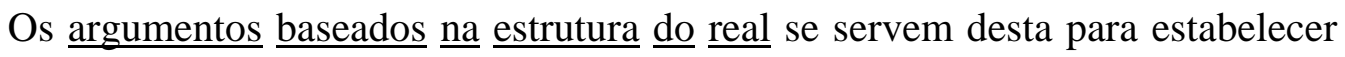
uma solidariedade entre premissas e conclusões. Pertencem a esta categoria os argumentos

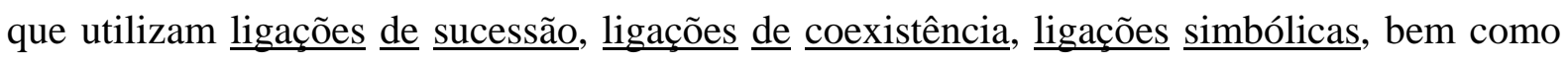
os argumentos de dupla hierarquia e os relativos a diferenças $\underline{\text { de grau ou de ordem. }}$.

A ligação de sucessão mais importante é a ligação causal, que dá origem à argumentação pela causa, pela qual, de um dado acontecimento, se infere sua causa, e ao argumento pragmático, pelo qual o valor concedido à consequência se transfere à sua causa.

\footnotetext{
${ }^{18}$ V., por exemplo, Billig (1987: 164).

${ }^{19}$ Um exemplo: "Toda esta arrogância [do governo Collor] só teria sustentação no sucesso absoluto. No fracasso, torna-se ridícula ou sintoma de desequilíbrio mental." (Folha de São Paulo, 08/02/91). O jornalista Gilberto Dimenstein, com isto, afirma a incompatibilidade entre a arrogância do governo e seu insucesso no plano econômico.
} 
As consequências de um acontecimento podem ser consideradas como deliberadas - caso em que elas serão fins, e a causa um meio - ou involuntárias, e esta interpretação pode ter efeito argumentativo. A primeira interpretação tende a fazer valorizar o fim, em relação ao meio, e a segunda, ao contrário, valoriza o fato, em relação à sua consequência. Ex: O esforço feito pelos ecologistas, especialmente do primeiro mundo, no sentido da preservação das florestas tropicais, é considerado por alguns como um meio de impedir a utilização plena, pelos países subdesenvolvidos, de seus recursos naturais. Uma interpretação alternativa é de que esta seria uma consequência da preservação, e mesmo assim meramente possível, e não necessária. Neste último caso, a atenção é atraída para a causa, que é única, quando as consequências são várias.

As ligações de coexistência "unem duas realidades de nível desigual, uma sendo mais fundamental, mais explicativa que a outra". De especial importância é a ligação entre pessoa (constituída por suas características consideradas importantes, naturais, essenciais) e ato (manifestação externa do sujeito, o que inclui seu discurso). Para Perelman, "a interação entre orador e discurso seria mesmo a característica da argumentação, por oposição à demonstração" (Perelman 1958: 426). O ato tende a ser interpretado em função da pessoa, que é o elemento mais estável desta dupla, e, além disto, capaz de intencionalidade. $\mathrm{O}$ que não impede que um ato modifique nossa concepção da pessoa, ou, que, ao fazê-lo, modifique a interpretação de outros atos da mesma pessoa. Desta forma, o conhecimento de atos passados permite a previsão de atos futuros. A interação ato-pessoa fundamenta, entre outros, o argumento de autoridade. Fundamenta também, no sentido inverso, o que Aristóteles chamava de éthos oratório: o discurso, através das opiniões nele expressas, influencia a opinião do auditório sobre o orador. Influencia também pela própria persuasividade do discurso: um discurso não-convincente reduz o status do orador frente ao auditório.

A interação ato-pessoa pode ser, no entanto, rompida. $\mathrm{O}$ ato, desde que seja considerado um fato (com a aceitação do auditório universal) não sofre a influência da opinião que o auditório tem sobre a pessoa. A interação ato-pessoa pode também ser reduzida. É o caso, por exemplo, quando o orador elogia o adversário, dando mostras de sua lealdade no debate, e evitando dar a impressão de que ele (o orador) vai julgar o discurso (ato) de seu adversário em função da pessoa. É o caso também do orador que alega ou aparenta neutralidade - procedimento de praxe no discurso científico, deve-se lembrar - de modo a evitar que seu discurso seja interpretado em função de sua pessoa, de seu pertencimento a determinado grupo social, de seus interesses pessoais, de sua própria condição de orador - interessado, por este motivo, em convencer. 
Análogas às interações entre pessoa e ato são as interações do tipo grupo-

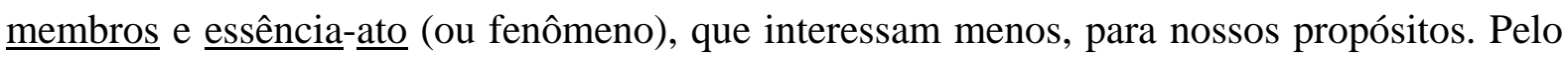
mesmo motivo abstemo-nos de descrever as ligações simbólicas.

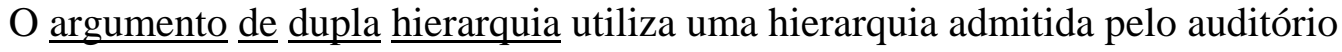
para fazê-lo aceitar uma outra hierarquia, apresentada como análoga à primeira ou por ela implicada, por uma ligação de sucessão ou coexistência. Ilustram este argumento os seguintes exemplos de Aristóteles: "De dois agentes de produção, é preferível aquele cujo fim é melhor" e "se os deuses não são oniscientes, com mais razão os homens" - sendo este último também um argumento a fortiori.

E ainda entre os argumentos baseados na estrutura do real estão os argumentos

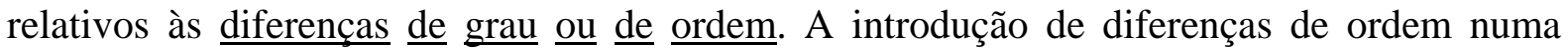
argumentação pode servir para minimizar as diferenças de grau. Por exemplo, um promotor pode chamar a atenção para a proposição de que um pequeno delito é, de qualquer forma, um delito. Ao fazer isto, ele coloca em primeiro plano a distinção permitido-proibido, e minimiza a diferença de grau entre o delito grande e o pequeno. Ao contrário, para minimizar uma diferença de ordem, o orador pode introduzir outras diferenças de ordem julgadas mais importantes, ou transformar a diferença de ordem numa diferença de grau. Mantendo o exemplo, pode-se deslocar a questão do par permitido-proibido para o justo-injusto, ou crime-delito, e defender o acusado nestes planos. Ou então acentuar as diferenças (de grau) entre o grande e o pequeno delito, o que por si só já aproxima o pequeno delito do não-delito.

Os procedimentos de ligação incluem, além dos argumentos quase-lógicos e dos baseados na estrutura do real, os argumentos que fundam a estrutura do real, de que trataremos agora. Estes últimos se subdividem em fundamento pelo caso particular e raciocínio por analogia.

O fundamento pelo caso particular se manifesta na argumentação pelo

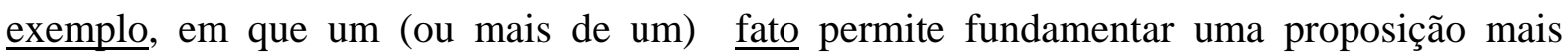
abstrata, uma regra, da qual se pode inclusive retirar outras conclusões particulares, que seriam outras tantas aplicações desta regra. A ilustração difere do exemplo por servir para reforçar a adesão a uma regra já admitida, aumentando sua presença. Por isto mesmo a ilustração não precisa ser, como o exemplo, um fato. Já o modelo é um caso particular (uma ação particular que tem o apoio do auditório) que incita a uma ação inspirada nele.

O raciocínio por analogia recorre a uma semelhança de estruturas em dois domínios do conhecimento. A relação admitida em um determinado domínio - ao qual se dá o nome de phore - é usada para fazer admitir uma relação similar em outro domínio - chamado thème. É assim, por exemplo, que Simonsen (1989: 159) apresenta os métodos de equilíbrio parcial e macroeconômico (thème) como análogos aos atos de "se fixar nas árvores e se esquecer da floresta" e "enxergar a floresta sem se preocupar com as árvores" (phore). A 
analogia se enriquece quando interage com um argumento de dupla hierarquia. Retomando o exemplo acima: Simonsen introduz na analogia também o método de equilíbrio geral, que corresponderia a levar em conta ao mesmo tempo as árvores e a floresta. Da hierarquia evidente no domínio do phore (o melhor possível é enxergar tudo) ele conclui: "Idealmente, o primeiro método [de equilíbrio geral] parece superior a qualquer outro".

A analogia pode ser usada para (des)valorizar o domínio do thème, ao se (des)valorizar o phore. Mas essencialmente, ela estrutura o domínio do thème a partir do domínio do phore. A esse propósito, vale a pena citar o trabalho de Mirowski (1987, entre outros) onde se procura demonstrar que a teoria neoclássica foi construída como uma analogia quase ponto-a-ponto com a mecânica racional do século XIX. A analogia, para além de seu valor como prova, ou recurso retórico, tem um papel heurístico, de estabelecimento e hierarquização de relações. Ela enfatiza as que fazem parte do thème e despreza as demais, 0 que se constitui num elemento importante do processo científico (v. p. ex., Bicchieri 1988). Segundo Perelman (1958: 531) a evolução da metáfora no campo científico (mas não só nele) leva à unificação do thème e do phore, que se tornam exemplos, casos de aplicação de uma regra, ou teoria, mais geral.

A refutação da analogia pode ser feita por seu prolongamento. Mirowski, no artigo citado acima, afirma que os teóricos neoclássicos escamotearam certos aspectos de sua analogia, que não tinham significado econômico. Com esta crítica Mirowski enfraquece toda a analogia e, mesmo aos que discordam de seu raciocínio, faz lembrar o caráter arbitrário (porque analógico) do empreendimento neoclássico.

Enquanto a analogia pode ser representada por uma estrutura do tipo "A está para B assim como C está para D", a metáfora pode ser descrita como uma analogia condensada, em que só aparecem alguns destes elementos. Um exemplo: uma analogia como "o equilíbrio microeconômico (A)(igualdade entre oferta e demanda) está para um mercado (B) assim como o equilíbrio (C)(físico) está para um sistema físico (D)" pode ser resumida como "equilíbrio de mercado" (C de B). Outras variações são possíveis: "picos e vales" (do ciclo econômico - C e D), "o oligopólio é um jogo não-cooperativo" (A é C), "mão invisível" (C), entre inúmeros outros. Sob um certo aspecto, a metáfora é retoricamente mais eficiente que a analogia: seu caráter analógico é menos explícito, o que suaviza para o auditório a passagem do phore ao thème.

A metáfora pode perder suas propriedades argumentativas, à medida que o uso intenso desgasta seu aspecto "anormal", de expressão usada em um domínio diferente do original. É o que ocorreu com a noção de equilíbrio em economia, que, se em seus primórdios evocava claramente sua origem na ciência física, e por isto era persuasiva, hoje tem um (ou mais de um) significado econômico estrito, literal, perfeitamente imbricado no restante da teoria econômica. Segundo Bicchieri (1988: 104) esta evolução é uma característica básica 
das metáforas científicas, que as diferencia das metáforas puramente literárias. O que não quer dizer que estas últimas sejam estáticas: elas podem perder seu apelo, tornando-se metáforas "adormecidas" ou, no limite, catacreses.

Todos os procedimentos retóricos até agora citados são procedimentos de ligação. Falta apresentar o conceito simétrico de procedimentos de dissociação, que podem consistir na ruptura de uma ligação julgada espúria pelo orador, restabelecendo a independência dos elementos originais, ou na dissociação de uma noção unitária desde a sua criação, dando origem a novas noções.

A dissociação das noções é provocada pelo desejo de superar uma incompatibilidade. Adam Smith (1983: 61) supera o paradoxo do diamante e da água dissociando o conceito de valor em valor de uso e valor de troca. O protótipo de todas as dissociações nocionais, tais como meio-fim, normal-norma, particular-geral, contingentenecessário, abstrato-concreto, corpo-alma etc. É, na visão de Perelman, o par aparênciarealidade.

A necessidade de distinguir uma da outra nasce das incompatibilidades entre aparências, que obrigam a escolher uma delas (ou algo diferente de quaisquer das aparências) como mais fundamental. Realizada esta operação, a realidade, que deve ser coerente, fornece uma regra que permite distinguir as aparências consistentes com a realidade das que não o são - uma regra deste tipo está contida numa expressão como "véu monetário", que condena os fenômenos monetários ao domínio das aparências. Da mesma forma, a distinção entre o "lado real" e o "lado monetário" da economia pode ter o mesmo efeito. É evidente, do que foi dito, que a dissociação valoriza o termo considerado como realidade e desvaloriza o outro. A dissociação pode surgir também de uma definição, que se pretenda a verdadeira definição, por oposição à definição usual, aparente: "o trabalho é a medida real do valor de troca de todas as mercadorias" (A. Smith 1983: 63).

A dissociação pode ser refutada, por exemplo, dizendo-se que a dissociação era ilusória, ou seja, introduzindo outra dupla, a verbal-real. Ou revertendo a dupla original: a dupla interpretação-letra (da lei), que opõe a diversidade das interpretações à unidade da lei escrita, pode ser transformada em letra-espírito, onde cabe à letra da lei o caráter equívoco e a uma determinada interpretação (espírito) o caráter essencial.

Uma dissociação em particular deve ser destacada, porque ela se reflete na própria discussão sobre a retórica e sua legitimidade: a dissociação artifício ("procedimento") - real. Se o discurso é considerado pelo auditório como mero artifício, manipulação da forma com o fim de convencer, ele é por isto mesmo desqualificado ${ }^{20}$, ainda que os argumentos nele presentes nada tenham de mecânico ou forçado. Esta qualificação de artificial só se

${ }^{20}$ É este o motivo pelo qual Mirowski (1987: 74) afirma que "a análise retórica é congenitamente crítica": porque ela permite identificar os procedimentos retóricos e, assim, desqualificá-los. 
coloca se o discurso se afasta da concepção que o auditório tem do real, que é o seu critério para separar os argumentos e proposições admissíveis dos não admissíveis ${ }^{21}$. Ora, se se passa da questão da legitimidade do uso de certo argumento num determinado contexto (que inclui a concepção que o auditório tem do real) à questão muito mais abstrata da legitimidade do argumento retórico em geral, desaparece o contexto e com ele o critério que permitiria fazer a dissociação artifício-real. A não ser que estejamos dispostos a admitir a proposição, ousadamente metafísica, de que o real só é acessível através da evidência formal ou sensível. Em qualquer outro caso, não há uma realidade que possa ser contraposta de forma absoluta à retórica. Em particular quando se admite, como nós fazemos, que nossa concepção do real se forma em meio a discursos, e em grande medida através deles.

Uma vez vistos os aspectos mais relevantes, para nossos propósitos, das técnicas argumentativas, cumpre fazer algumas observações sobre a força dos argumentos, sua interação e ordenação no discurso.

A força de um argumento é uma noção indispensável, conquanto confusa, e que orienta o orador na escolha dos argumentos e em sua ordenação. A força está relacionada ao grau de adesão do auditório às premissas e ligações, e à relevância que o auditório atribui ao argumento para o debate de que se trata. O orador pode aumentar esta força, lembrando ao auditório sua adesão a certas premissas mais fortes, ou dando por logicamente demonstrado o que foi apenas argumentado. Ele pode mesmo afirmar explicitamente a força do argumento, criando, assim, um argumento adicional. Uma técnica oposta para aumentar a força do argumento é a técnica de atenuação, que consiste em manter a conclusão aquém do que o auditório estaria disposto a conceder. Esta técnica visa ganhar a confiança do auditório, afastando dele a possibilidade de que o discurso seja um artifício.

Um aspecto essencial da argumentação, que a diferencia da demonstração lógica, é que os argumentos interagem entre si, podendo-se reforçar mutuamente ou prejudicar um ao outro. Um caso eminente é o da interação por convergência, que ocorre quando vários argumentos independentes levam à mesma conclusão. Neste caso o valor atribuído à conclusão e a cada elemento isolado será aumentado, "pois parece inverossímil que vários argumentos inteiramente errôneos conduzam a um mesmo resultado" (Perelman 1958: 624). Por outro lado, a convergência pode dar origem a uma dissociação naturalartificial, pela qual os argumentos não teriam convergido naturalmente, mas teriam sido interpretados ou manipulados pelo orador de forma a convergir. $\mathrm{O}$ tamanho do discurso, que corresponde ao número de argumentos, é, evidentemente, uma variável controlada pelo orador. Enquanto num contexto lógico a brevidade é uma virtude, no contexto argumentativo o maior número de argumentos permite aproveitar o efeito de convergência. Além disto, o

${ }^{21}$ Este aspecto é admitido por Machlup (1967: 96), que relativiza a crítica semântica (na verdade, retórica) que ele próprio faz do discurso econômico, ao afirmar que ele tende a ver manipulação do sentido das palavras apenas nos textos com os quais não simpatiza. 
auditório-alvo pode ser heterogêneo, exigindo argumentos adequados a cada divisão do auditório. Outra situação: uma argumentação complementar pode servir para superar as dificuldades que se opõem à aceitação da argumentação principal, ou de suas premissas.

O tamanho do discurso é, no entanto, limitado por uma série de considerações: temporais, espaciais, a progressiva redução da atenção do auditório, o perigo de que um argumento fraco, polêmico ou irrelevante restrinja, ao invés de aumentar, a adesão do auditório etc. Mas, ao invés de se ampliar o discurso, pode-se usar outros recursos: um deles é a renúncia explícita a argumentos adicionais. Assim não só o orador testemunha objetividade e mesmo generosidade frente ao adversário, mas também mostra confiança na força dos argumentos remanescentes. Um exemplo espetacular deste tipo de renúncia é a defesa que Sobral Pinto fez de Luiz Carlos Prestes com base no artigo 14 da Lei de Proteção aos Animais, na década de 1940. Ao deixar de lado a defesa que seria de se esperar, com base no Código Penal ou outro código adequado a homens, o advogado enfatizou a força do seu argumento.

Finalmente, listamos algumas considerações relativas à ordem do discurso. Esta se orienta pela necessidade de "obter novas premissas, dar presença a certos elementos e obter certos engajamentos da parte do interlocutor". Os fatos, que gozam do apoio do auditório universal, são colocados, via de regra, no começo do discurso. Também no começo (o clássico exórdio) são colocadas frequentemente indicações da competência, imparcialidade e honestidade do orador, visando ganhar a confiança do auditório. Para mostrar uma incompatibilidade no discurso do adversário, há que colocar lado a lado os argumentos julgados incompatíveis. Situações diferentes podem sugerir o emprego de uma ordenação crescente, decrescente ou nestoriana, ou seja, que colocam os argumentos mais fracos respectivamente no começo, no fim ou no meio do discurso. Há uma série de outras regras para determinar a ordenação ótima. Contudo, são extremamente dependentes do contexto, o que lhes reduz o interesse. De qualquer modo, aqui, como em todas as considerações anteriores, a regra geral está na adaptação ao auditório, o fio tênue de que o orador dispõe para se orientar no labirinto do discurso.

\section{I.3- $\underline{\text { Abordagens }}$ alternativas}

Ao estudar a retórica pelo ângulo de uma teoria da argumentação, Perelman se distancia do estudo da expressão e interpretação linguísticas, e mais ainda do estudo literário. O que ele faz é fornecer um quadro conceitual que permite elucidar as justificações de todo tipo apresentadas em defesa de valores e regras. Tal abordagem é particularmente adequada 
para nossos propósitos, de elucidar um discurso tão voltado para as decisões práticas de política econômica, como é o da CEPAL.

Eximimo-nos de apresentar e utilizar outras teorias retóricas antigas e modernas, entre as quais as de Aristóteles, Quintiliano, Cícero, Pascal, Adam Smith, Whately, Burke, Booth etc. Em primeiro lugar, porque o esforço de familiarização, discussão e compatibilização deste grande número de visões divergentes está muito acima das possibilidades de um economista e dos limites temporais admissíveis para uma dissertação de mestrado. Em segundo lugar porque uma tal tentativa de síntese foi realizada por Perelman, de maneira que julgamos mais produtivo concentrar esforços na aplicação de uma única teoria da argumentação a um texto econômico, evitando o mosaico de interpretações e de terminologias divergentes que se formaria, fosse outra nossa escolha.

De toda sorte, merecem menção algumas abordagens contemporâneas alternativas e em certa medida complementares. Ressalvamos, porém, que não pretendemos apresentar uma listagem exaustiva.

Os estudos do grupo $\mu$ belga (Dubois et alii 1970 e 1980) entendem todos os procedimentos retóricos da literatura, e da poesia em particular, como afastamentos, transgressões da norma linguística. A tais afastamentos dão o nome de metáboles. A partir daí, constróem um (novo) quadro conceitual para classificação das diferentes metáboles. Tal quadro constituiria uma "retórica geral". A retórica proposta pelo grupo $\mu$, por sua vinculação à linguística, prende-se (com exceção do último capítulo de Dubois et alii 1970) ao estudo da frase, deixando de lado os fenômenos discursivos referentes às relações entre frases e à estruturação geral do discurso.

Noutra vertente, o filósofo analítico de Oxford J. L. Austin ${ }^{22}$ distingue três níveis em que se podem realizar os proferimentos linguísticos: a) a locução, nível mais básico, que se diferencia da locução meramente física apenas pelo fato de obedecer às regras sintáticas e semânticas de uma determinada língua; b) a ilocução, pela qual o locutor, com seu proferimento, constata um fato, descreve um objeto, faz uma promessa, expõe uma opinião etc. Percebe-se, por estes exemplos, a natureza convencional do ato ilocucionário: proferir certas frases (ato locucionário) equivale a fazer algo (constatar, descrever, prometer etc.); c) a perlocução, pela qual se obtém um determinado efeito intencional no interlocutor: persuadir, intimidar, tranquilizar, emocionar etc. O estudo dos diversos níveis do ato linguístico total e de suas interações constituiria um caminho possível para a compreensão das formas da persuasão através de meios discursivos, que é o objeto próprio da retórica.

A professora Koch, em seu livro "Argumentação e linguagem", faz um apanhado de teorias que estão na fronteira entre linguística e retórica, como as de Ducrot,

\footnotetext{
${ }^{22}$ Cf. Almeida (1981 cap. 2).
} 
Anscombre, Vogt, Weinrich etc., propondo uma classificação dos recursos retóricos em retórica integrada (recursos constitutivos do sentido, presentes na gramática) e retórica aplicada (manobras discursivas que se superpõem ao nível linguístico fundamental). No primeiro grupo estão os pressupostos, elementos implícitos, mas nem por isto menos importantes para a compreensão do discurso; os modalizadores, que marcam a atitude do locutor em relação ao enunciado; o fenômeno da polifonia de Ducrot, em que o ato ilocucionário de asserção é atribuído a outro que não o locutor; os operadores argumentativos (na linha da semântica argumentativa) como os conectivos mas, porém, embora, já que etc. e vocábulos não classificados gramaticalmente, como até, também, aliás, senão, entre outros; o uso dos tempos verbais, e a correspondente distinção entre o mundo comentado e o mundo narrado. Pertencem à retórica aplicada a ironia, a sátira, a insinuação, o sarcasmo, a alusão, o uso retórico da pressuposição (colocar como pressuposto justamente a informação que se quer veicular), a seleção lexical, o argumento de autoridade etc.

Toulmin, em "The uses of argument" (1958), faz uma crítica ao silogismo aristotélico (estruturado em premissa menor - premissa maior - conclusão), que ele propõe substituir por uma estrutura mais complexa, e na qual ressalta o papel das fundamentações (backings). Tais fundamentações - e este é o ponto importante - são de tipos lógicos variados, segundo os diferentes campos dos argumentos - ético, legal, geométrico, biológico etc. De acordo com Toulmin, a lógica tradicional toma como paradigma o argumento analítico (aquele cuja fundamentação inclui a informação fornecida pela conclusão e que, portanto, independe do campo do argumento), conformando a este modelo ou mesmo desprezando os demais argumentos, denominados por ele substanciais. Para estes últimos, que são os únicos capazes de produzir conhecimentos novos, a validade só pode ser apreciada pelos padrões próprios de cada campo. O papel do lógico, nesta visão, seria principalmente o de observar e explicitar a forma lógica dos argumentos em uso nos diferentes campos, e em diferentes períodos históricos, sem procurar conformá-los necessariamente a um padrão comum. Este ponto de vista é compartilhado por Toulmin e Perelman, que diferem, no entanto, em outro ponto: enquanto Perelman põe no centro de sua análise o fenômeno (psicológico) da persuasão, Toulmin rejeita explicitamente considerações psicológicas e fisiológicas (sic), preocupando-se com relações (lógicas) entre as afirmações e os argumentos apresentados para fundamentá-las.

Uma abordagem correlata é a realizada pelos estudos de "lógica natural", entre os quais tomamos como exemplo um artigo de Borel e Vignaux (1971), "Stratégies discursives et aspects logiques de l'argumentation". Os autores frisam que a análise por eles realizada não se aplica a todo discurso argumentativo, mas àqueles (ou partes deles) cujas proposições parecem encadear-se, umas justificando, consolidando etc. as outras. É preciso observar, no entanto, que mesmo estes não explicitam certas premissas, julgadas conhecidas do interlocutor, ou não explicitam conclusões, julgadas óbvias. Torna-se necessário, portanto, 
antes de formalizar o argumento expresso em linguagem natural, completar suas lacunas. Os autores procuram mostrar, neste texto, como se pode interpretar uma sequência aparentemente simples de duas frases do ex-presidente Georges Pompidou como um encadeamento de proposições lógicas (que são as unidades de análise por eles utilizadas) levando a uma conclusão. Mesmo considerando os limites à formalização levantados pelos próprios autores, este se constitui num caminho possível para a análise do discurso.

Outra abordagem possível, esta desenvolvida visando um discurso argumentativo específico, o da ciência (no caso, da ciência econômica), é a adotada por Johnson (1971) em seu artigo "Keynesian revolution and the monetarist counter-revolution". Johnson estuda estas duas revoluções teóricas procurando apresentar a "técnica revolucionária", os aspectos formais que, na sua visão, juntamente com o contexto histórico, foram importantes para sua aceitação. Em particular, a colocação em primeiro plano de um problema econômico e social importante com o qual as ortodoxias anteriores não eram capazes de lidar; e uma série de características das novas teorias que atraíram as novas gerações e repeliram as antigas. Silveira, em artigo recente (1990), retoma as sugestões de Johnson, aplicando-as à teoria da escolha pública. Tanto o artigo de Harry Johnson quanto o de Silveira são marcados pelo tom crítico em relação às teorias que estudam, e, aparentemente, também aos artifícios por elas utilizados para convencer.

O projeto de Arida (1984) é mais ambicioso, na medida em que procura englobar todo o pensamento econômico, e mais radical, ao fazer da análise retórica não um instrumento de crítica, mas de compreensão do discurso econômico. Arida busca abstrair da história do pensamento econômico as regras de retórica que provêm um substrato comum, ou seja, aceito consensualmente, "que permite a homogeneidade do discurso, de suas formas de argumentação e portanto de evolução" (Arida 1984: 43).

O conjunto de regras ideal seria aquele que permitisse explicar a vitória de determinadas teorias (ou correntes teóricas) nas controvérsias históricas, sendo supostamente vencedoras as teorias que se aproximassem mais dos cânones retóricos vigentes. Arida não procura explicar, pelo menos no atual estágio de suas pesquisas, o processo de mudança dos padrões retóricos.

Ainda uma outra visão da retórica na economia é a apresentada por Mirowski (1987), o qual avança a polêmica hipótese de que o cerne da teoria neoclássica foi construído por analogia com a mecânica do século XIX, com a utilidade ocupando o lugar da energia potencial. Ele atribui o sucesso desta teoria, no entanto, não ao uso da metáfora em si, mas: a) ao fato de permitir a transferência do instrumental matemático correntemente utilizado na Física (e que era em grande medida responsável pelo status científico desta disciplina) para a Economia; b) ao fato de esta analogia conferir um caráter atemporal ao capitalismo; c) à primazia concedida ao indivíduo como fator explicativo dos fenômenos econômicos; d) e, 
principalmente, por fundar a ordem social (econômica) em uma ordem natural, sendo este "um princípio básico da compreensão humana" (Mirowski 1987: 92). Note-se que o ensaio de Mirowski se caracteriza pela procura das crenças e inclinações do auditório que o tornam mais propenso a aderir a um ou outro padrão retórico, indo, neste sentido, além dos autores anteriormente citados. 


\section{II- CONTEXTO}

\section{II.1- Panorama ideológico}

É importante, para nossos propósitos, detectar o clima de opinião reinante na América Latina, particularmente quanto à necessidade e propriedade da industrialização e adoção de medidas protecionistas, no período de criação da CEPAL.

Os dados - embora fragmentários e incompletos - de que dispomos nos inclinam a aceitar a abalizada opinião de Echavarría (1969), que aponta um paradoxo do comportamento político nos países latino-americanos. Este se pauta desde a independência pela defesa, a nível ideológico, do liberalismo político e econômico, mas se baseia, efetivamente, numa estrutura social fundamentalmente agrária que lhe é contraditória. O surgimento e a importância adquirida pelos fascismos na Europa vieram agregar um elemento a mais à confusão ideológica reinante na América Latina. Nas palavras desse sociólogo, "veemências implícitas em todo nacionalismo jovem, resíduos de certas influências alemãs, afirmações marxistas de todo tipo e matiz, mais elementos liberais e metas tecnológicas comuns a todos os povos desta época, formavam uma trama mental difícil de ordenar em decisões claras, sustentadas e factíveis" (Echavarría 1969: 66).

Acrescenta-se a este quadro já complexo a ascensão das burguesias industriais, com o crescimento industrial acelerado durante a Grande Depressão e a II Guerra Mundial, e a concomitante perda da hegemonia política pelas oligarquias rurais.

$\mathrm{Na}$ impossibilidade de apresentar toda a ecologia ideológica latino-americana no período que nos diz respeito, selecionamos alguns aspectos dela e da política econômica nos países mais importantes da região.

Na Argentina da década de 1920, a teoria clássica das vantagens comparativas era amplamente aceita, com o resultado de uma oposição também ampla a medidas protecionistas. Até mesmo o Partido Socialista argentino partilhava esta opinião ${ }^{23}$. A Grande Depressão, no entanto, forçaria uma revisão destes pontos de vista. A Argentina, altamente dependente de exportações primárias em rápida queda, foi o primeiro país a abandonar o padrão-ouro (dezembro de 1929). Dois anos mais tarde introduziu controles de câmbio.

Medidas mais radicais seriam adotadas no governo populista de Perón (19461955). Este governo introduziu um controle de divisas mais estrito, com um sistema de taxas múltiplas de câmbio que favorecia a importação de matérias-primas para a indústria e protegia especialmente a indústria de bens de consumo. O Banco Industrial, criado em 1944,

${ }^{23}$ Cf. Love (1980: 48). 
aumentou em muito suas atividades, o que se soma a uma política de concessão de empréstimos a certos setores a juros reais muitos baixos ou mesmo negativos. $\mathrm{O}$ nacionalismo se manifestava na total indiferença, quando não hostilidade, ao capital estrangeiro, e na nacionalização das empresas ferroviárias e outras empresas de serviços. Porém, a característica mais marcante deste governo, no plano econômico, foi a redistribuição de renda que provocou através da política salarial, subsídio ao consumo e crescimento do sistema previdenciário.

No México, a revolução (1910-1917) foi "o primeiro grande assalto ao bastião do liberalismo, em seu aspecto de laissez faire" ${ }^{24}$. É patente também seu caráter nacionalista e desenvolvimentista, que se concretiza na constituição de 1917 e se transmite aos governos posteriores. Os governos pós-revolucionários praticam, de modo geral, uma política populista, policlassista, que coloca o Estado como árbitro das relações sociais e regulador da economia, de forma análoga ao populismo de Getúlio Vargas, no Brasil. O Governo Cárdenas (1935-1940) levou avante um extenso programa de reforma agrária, nacionalizou as estradas de ferro e, sua ação mais espetacular, nacionalizou a indústria do petróleo, colocando-a sob o controle da companhia estatal PEMEX. A política de industrialização esteve restrita ao processamento de produtos primários. O Governo Camacho (1941-1946) seguiu, favorecido pelas condições de guerra, uma política francamente industrialista, assim como o governo seguinte, de Miguel Alemán (1947-1952), adotando incentivos fiscais e creditícios, impondo controles diretos sobre as importações, elevando tarifas alfandegárias e atraindo capital estrangeiro.

No Brasil, posições anti-liberais mais marcadas surgem com a Revolução de 1930. Getúlio Vargas, em discurso de $1931^{25}$, adverte para as falhas do sistema de livre mercado e a necessidade de regulá-lo e discipliná-lo.

Ao mesmo tempo, abundam as manifestações de nacionalismo, que remontam, no plano cultural, ao movimento modernista da década de 1920. No plano político, ressaltam o tenentismo, o integralismo, a legislação da década de 1930 - em particular as constituições de 1934 e 1937 e a lei sobre "atos contrários à economia nacional" e "nocivos ao interesse público", de 1945. Esta lei, um dispositivo anti-truste, visava principalmente se contrapor ao poder econômico das empresas estrangeiras. No plano econômico ${ }^{26}$, são de se notar os debates relativos à "grande siderurgia", à exploração das jazidas petrolíferas e - o que mais nos interessa - os incentivos à indústria. Nacionalismo, desenvolvimentismo e industrialismo formam um todo, como no discurso de Getúlio Vargas em Volta Redonda, em 1943: "O problema básico da nossa economia estará, em breve, sob novo signo. O país semicolonial, agrário, importador de manufaturas e exportador de matérias-primas, poderá arcar com as

\footnotetext{
${ }^{24}$ Cf. Alba (1960: 219).

${ }^{25}$ Cf. Ianni (1986: 31).

${ }^{26}$ Com o perdão da distinção excessivamente rígida entre este e o político.
} 
responsabilidades de uma vida industrial autônoma, provendo as suas urgentes necessidades de defesa e aparelhamento." 27

Estas mesmas teses foram defendidas no I Congresso Brasileiro de Economia, realizado em 1943, e que reuniu empresários de todos os setores, economistas, funcionários do governo, professores universitários e técnicos.

É emblemático do choque de opiniões entre nacionalistas-industrialistas e internacionalistas-liberais da época o debate entre Roberto Simonsen, importante industrial, e Eugênio Gudin, professor de economia ${ }^{28}$ Simonsen defendia a industrialização do país, conjugada com proteção alfandegária e planejamento estatal. Gudin, no pólo oposto, pregava a privatização da economia, a livre participação do capital estrangeiro e a não-interferência do poder público na alocação dos fatores de produção.

No imediato pós-guerra perdem espaço os setores nacionalistas-industrialistas. A derrota do nazi-fascismo e a deposição de Getúlio criaram as condições para a reafirmação dos princípios liberais (no campo econômico, inclusive), o que se expressa na constituição de 1946 e na liberalização das importações no Governo Dutra.

Para o conjunto da América Latina, dois aspectos conjunturais devem ser lembrados. Do fim da II Guerra até a metade dos anos 1950, a região viveu, embora com variações conjunturais e diferenças entre países, um período de auge das exportações. Ora, este movimento dava, aos interesses e círculos de opinião contrários à industrialização, um argumento adicional, tornando mais plausível a tese de que o crescimento da produção industrial durante a guerra era (e deveria ser) somente transitório. Segundo ponto: Os EUA se encontravam, ao findar a II Guerra, em uma posição de hegemonia incontestável. Este fator, se por um lado reforçava os grupos liberais, contrários à intervenção do Estado, por outro acirrava os ânimos dos nacionalistas.

À CEPAL coube o papel de contrarrestar a vaga liberal, afirmando a racionalidade do processo de industrialização e sua irreversibilidade.

\section{II.2- Antecedentes teóricos}

Um ponto bem estabelecido na literatura sobre a CEPAL é o de que, além de não ter sido Prebisch o primeiro a pensar na necessidade de industrialização, alguns dos argumentos por ele utilizados também têm precedentes.

\footnotetext{
${ }^{27}$ Apud Ianni (1986: 74).

${ }^{28}$ Esta controvérsia, ocorrida em 1945, foi editada em Simonsen (1977).
} 
Hodara (1987 a e b) opina que Prebisch se inspirou em três fontes principais: Ernst Wageman, Mihail Manoilesco e a obra coletiva dirigida por S. E. Harris. Wageman, economista teuto-chileno, já em 1932 defendia teses sobre a vulnerabilidade das "economias periféricas" ao ciclo econômico a que estava submetido o sistema capitalista como um todo. Defendia, por este motivo, a ação estatal de modo a gerar "um ciclo interno" compensador e a industrialização dessas economias. Love ${ }^{29}$ contesta a importância atribuída por Hodara a Wageman na formação das idéias cepalinas.

Manoilesco, economista e ministro da fazenda da Romênia, considerava, já em 1929, o livre comércio um mecanismo de exploração dos países produtores de bens primários por parte dos países industrializados. O argumento era de que estes últimos trocavam bens produzidos em condições de alta produtividade por outros produzidos com uma produtividade muito menor. Justificava, desta forma, a adoção de medidas protecionistas que possibilitassem um programa de industrialização das economias agrárias. Em 1931, Roberto Simonsen mandou traduzir para o português o trabalho econômico mais importante de Manoilesco, "Théorie du Proteccionisme" (1929). No entanto, Prebisch ${ }^{30}$ não admite a influência de Manoilesco em seu pensamento.

O economista americano S. E. Harris e seus colaboradores, no livro "Problemas Econômicos da América Latina", de 1945, destacaram a agricultura tradicional como o principal problema econômico da região, por impedir a modernização e o rompimento das relações feudais, além de ser o mercado externo dos produtos primários eminentemente instável. Ademais, argumentavam que o efeito multiplicador das exportações era reduzido, devido à debilidade dos relacionamentos intersetoriais internos.

Love (1980: 62-3) localiza o primeiro uso do conceito de centro e periferia em Werner Sombart, que, em 1928, escreveu: "Nós devemos [...] distinguir um centro capitalista - as nações capitalistas centrais - de uma massa de países periféricos vistos deste centro; os primeiros são ativos e condutores, os últimos, passivos e subordinados" (grifos nossos).

Colin Clark é citado num artigo de Víctor Urquidi para "El Trimestre Econômico" (jan-mar 1946) ${ }^{31}$. A ligação que faz entre o processo de desenvolvimento e o deslocamento da população do setor primário para o secundário e terciário é utilizada por Prebisch no Estudio ${ }^{32}$.

\footnotetext{
${ }^{29}$ Em comunicação pessoal ao autor.

${ }^{30}$ Cf. Love (1978: 54).

${ }^{31}$ Cf. Hodara (1987 a: 390) e Pazos (1983: 1925).

${ }^{32} \mathrm{~V}$. cap. III adiante.
} 


\section{II.3- Outros teóricos do desenvolvimento}

A Economia do Desenvolvimento como uma disciplina independente surgiu apenas depois da II Guerra Mundial. Não nos deteremos nela aqui, a não ser para tratar da direção geral de sua evolução e destacar alguns nomes anteriores ou contemporâneos do período inicial da CEPAL (1949).

Singer (1961) destaca, como elemento comum aos teóricos do desenvolvimento desta época, o pessimismo em relação às possibilidades de desenvolvimento dos países pobres. Todos eles (e a CEPAL não constitui exceção) enfatizam os obstáculos consideráveis que estes países deveriam superar. Tal pessimismo contrasta fortemente com a visão corrente no longo período que vai de Ricardo a Keynes, durante o qual as preocupações, quando existiam, se dirigiam à possibilidade de estancamento do crescimento dos países desenvolvidos. Os países subdesenvolvidos pareciam, por seu próprio estado de atraso relativo, não estar sujeitos a este problema.

Segundo Streeten (1989: cap. 5), nas décadas de 1950 e 1960 a teoria mais influente fora dos círculos acadêmicos foi a dos estágios do crescimento, de W. W. Rostow. Sua visão muito simples, para não dizer simplista, do desenvolvimento era a de uma evolução linear, com todos os países passando pelo estágio do take-off (decolagem) que conduziria ao estágio final, de país desenvolvido. Esta abordagem descuidava das mudanças sociais necessárias e consequentes ao processo de desenvolvimento, e ressaltava a existência de gargalos que era necessário superar para produzir o take-off. Entre esses gargalos, aquele ao qual se dava maior importância era a falta de capital. Outros obstáculos identificados eram a insuficiência das disponibilidades de moeda estrangeira para importação de bens de capital, falta de mão-de-obra especializada e capacidade administrativa. Uma vez supridos estes elementos faltantes, o desenvolvimento se seguiria naturalmente. Consequentemente, as prescrições incluíam ajuda financeira aos países pobres, investimento estrangeiro, assistência técnica e intensificação do comércio.

Colin Clark, economista inglês, pioneiro no desenvolvimento dos sistemas modernos de contas nacionais, propôs em 1940, em sua obra "As condições do progresso econômico" (cap. 9), uma generalização empírica sobre a distribuição de mão-de-obra entre os setores da produção. À medida que aumenta a renda reduz-se a proporção da população economicamente ativa empregada na agricultura, aumenta na indústria e aumenta ainda mais rapidamente nos serviços. Colin Clark, com isto, ajuda a estabelecer a relação que se tornou tão "natural" entre desenvolvimento e industrialização.

Paul Rosenstein-Rodan, economista anglo-austríaco, publicou no Economic Journal em 1943 um artigo clássico, "Problems of industrialization of Eastern and South- 
Eastern Europe" (Rosenstein-Rodan 1963). O primeiro ponto ressaltado pelo autor é que existe um excesso de mão-de-obra agrária nestes países (desemprego disfarçado) que, dadas as dificuldades para a emigração de um contingente muito grande de pessoas, justificaria a industrialização. No entanto, não se deveria buscar a autarquia, mas o estabelecimento de indústrias leves, financiadas em parte por investimentos estrangeiros diretos e empréstimos. Rosenstein acentua especialmente as economias externas geradas por um bloco (de um certo tamanho mínimo) de investimentos complementares, que assegurassem demanda uns aos outros, além de investimentos na qualificação de mão-de-obra. Tal proposição tornou-se posteriormente conhecida como "teoria do big push" e tinha como corolário a introdução de um sistema de planificação e controle estatal da economia. O pacote de investimentos incluiria também a criação de indústrias básicas (como as relacionadas à produção de energia) e infraestrutura ali onde se tornassem necessárias devido ao aumento - gerado pelo pacote - da demanda.

Uma variação da teoria do big push, que enfatiza a complementaridade entre os diversos investimentos, é a teoria do "crescimento equilibrado", ligada ao nome do professor estoniano Ragnar Nurkse. Esta teoria conclui pela necessidade de desenvolvimento simultâneo de vários setores, de modo a que eles assegurem a criação de demanda uns para os outros. Nurkse pronunciou conferências no Rio de Janeiro em 1951, as quais, segundo Furtado (1985: 147-9), primavam menos pela originalidade que pela organização de uma série de idéias então correntes sobre o desenvolvimento ${ }^{33}$. Dentre estas idéias, havia a questão do desenvolvimento equilibrado, o círculo vicioso do subdesenvolvimento - a baixa renda não permite a criação de mercados que encoragem a aplicação de capital, o que perpetua a situação de baixa renda - e o efeito-demonstração - os padrões de consumo dos países adiantados se transferem para os setores de altas rendas dos países subdesenvolvidos, prejudicando a formação de poupança e a acumulação.

Não se pode deixar de mencionar o artigo de Hans Singer, funcionário das Nações Unidas, publicado na American Economic Review de maio de 1950 (Singer 1961). Este artigo apresenta essencialmente as mesmas idéias que Prebisch havia exposto em seu "manifesto" (Prebisch 1962) e no "Estudio Económico de América Latina - 1949" (CEPAL 1950) ${ }^{34}$. Prebisch afirma, no entanto, que não houve intercâmbio direto de idéias entre os dois, estando ele em Santiago do Chile e Singer em Nova Yorque ${ }^{35}$. O ponto de contato seria o trabalho estatístico das Nações Unidas em que ambos se baseiam, "Relative prices of exports and imports of underdeveloped countries" (Nações Unidas 1949). As proposições de ambos se tornariam conhecidas como "Tese Prebisch-Singer".

\footnotetext{
33 As conferências foram depois incluídas em seu livro "Problems of capital formation in underdeveloped countries", de 1953.

${ }^{34}$ Ver cap. III adiante sobre o Estudio.

${ }^{35}$ Cf. Love (1979: 53).
} 
Singer questiona os alegados ganhos gerados pelos investimentos estrangeiros no setor exportador dos países subdesenvolvidos, pelo fato de seu efeito multiplicador se dar, em grande medida, nos países desenvolvidos. Enfatiza ainda que este sistema de investimento estrangeiro ligado ao comércio internacional não provocou a industrialização dos países aos quais se dirigiu.

Defende a industrialização dos países subdesenvolvidos com, basicamente, dois argumentos: a) Além dos benefícios sociais diretos e das economias externas geradas por um processo intenso de industrialização, há uma elevação do nível geral de educação, maior dinamismo e adaptabilidade decorrentes da urbanização, aquisição de habilidades, aumento do estoque de tecnologia, criação de novas demandas etc. Este processo cumulativo de mudança econômico-social é que constituiria a principal explicação para o desejo generalizado de industrialização nos países subdesenvolvidos ${ }^{36}$. b) A tendência à piora dos termos de troca entre produtos primários e industrializados desde a década de 1870. Tal tendência é atribuída ao fato de o progresso técnico gerar, nos países mais desenvolvidos, exportadores de manufaturados, elevação da renda dos produtores, e não queda de preços. $\mathrm{O}$ oposto ocorreria nos países subdesenvolvidos, exportadores de produtos primários. Outras causas da deterioração seriam a baixa elasticidade-renda da demanda de alimentos e a redução relativa na utilização de matérias-primas devido ao progresso técnico nas manufaturas.

A política preconizada por Singer, a partir deste diagnóstico, inclui assistência técnica de forma a mudar a estrutura de vantagens comparativas dos países subdesenvolvidos, reinvestimento dos lucros das empresas estrangeiras nesses países (ou absorção destes lucros por meios fiscais), retenção dos frutos do progresso técnico nesses países através de aumento real de salários e outras rendas, e orientação destes incrementos na renda para poupança e consumo de produtos que fossem ou pudessem ser produzidos internamente.

\section{II.4- Prebisch}

Convém, antes de entrarmos na história da CEPAL, fazer um histórico da carreira de Raúl Prebisch, nome que se entrelaçou de tal maneira com a instituição que esta chegou a ser conhecida como "a CEPAL de Prebisch" ${ }^{37}$. Nascido em 1901, em Tucumán, Argentina, formou-se em Economia pela Universidade de Buenos Aires em 1923. Foi professor de Economia Política desta universidade de 1925 a 1948, realizando, neste período,

\footnotetext{
${ }^{36}$ Este argumento não é, curiosamente, utilizado por Prebisch.

${ }^{37}$ Biografias mais detalhadas estão em Di Marco (1972) e Love (1978, 1980, 1987). Uma lista exaustiva das obras de Prebisch, com 466 títulos, aparece em CEPAL (1987). Di Filippo (1988) organizou uma bibliografia comentada sobre Prebisch bastante útil.
} 
uma série de outras atividades. Segundo seu próprio testemunho, durante os anos 1920 "cria firmemente nas teorias neoclássicas" (Prebisch 1987: 13). Esta crença foi abalada pelo impacto da Grande Depressão sobre seu país. Hodara afirma que sua cultura era muito mais fragmentada que fruto de estudos sistemáticos.

Entre 1925 e 1927 foi funcionário do Departamento de Estatísticas argentino. Em 1927 publicou, sob os auspícios da poderosa Sociedade Rural Argentina, um estudo que serviu de base ao pacto Roca Runciman de 1933, referente às relações comerciais com a GrãBretanha, favorecendo as exportações de carne. Tal ligação com a oligarquia marcaria para sempre sua imagem na Argentina, apesar de seu trabalho na CEPAL e mesmo de sua obra posterior, de conotações crescentemente socialistas, ou, pelo menos, anti-liberais. De 1927 a 1930, foi Diretor de Pesquisas Econômicas do Banco Nacional da Argentina, e editor da revista do banco, "Revista Económica". Foi Subsecretário de Finanças (1930-1932) e consultor dos ministérios da Agricultura e Finanças (1933-1935), respectivamente nos governos dos generais José Uriburu e Agustín Justo. Organizou o Banco Central da Argentina (1935), do qual foi o primeiro Diretor-Geral. Nos informes anuais do banco e na Revista Económica, expressa algumas posições que mais tarde, já na CEPAL, viria desenvolver e generalizar. Entre elas, a idéia de que os ciclos econômicos da Argentina refletiam os dos países industrializados, de que os períodos de maior crescimento industrial estavam ligados às crises do setor externo, e a defesa da industrialização argentina como forma de reduzir a dependência externa. Em 1943 foi destituído do cargo devido ao golpe do qual Perón, com quem não simpatizava, emergiria como presidente eleito.

Prebisch volta, então, à universidade, onde ministrava um curso de "Dinâmica Econômica", que atraía também o público extra-universitário. Em 1946 formula pela primeira vez os conceitos de centro e periferia. Escreve também o livro "Introdução a Keynes", veículo da difusão do pensamento keynesiano na América espanhola. Depois de uma curta estada no México, como consultor do Banco Central, é chamado para trabalhar no secretariado da CEPAL, em 1948.

\section{II.5- $\underline{\text { A criação da CEPAL }}$}

Nosso interesse é descrever o processo da criação da CEPAL e os interesses políticos envolvidos, os quais posteriormente se refletirão de forma marcante na teorização cepalina ${ }^{38}$. O primeiro projeto de resolução, de iniciativa do Chile, propondo a instituição de uma Comissão Econômica para a América Latina, data de 12 de julho de 1947. Nele já

\footnotetext{
${ }^{38}$ No que se segue usaremos basicamente os relatos do diplomata chileno Hernán Santa Cruz (1985), um dos promotores da criação da CEPAL dentro do Conselho Econômico e Social da ONU, e do economista brasileiro Celso Furtado (1985), técnico da CEPAL no período de sua constituição.
} 
constam, entre as justificativas do empreendimento, a necessidade de "desenvolver a indústria dos países da América Latina e utilizar ao máximo seus enormes recursos naturais para elevar o nível de vida de seus habitantes..." (Santa Cruz 1985: 12 - grifo nosso). O projeto encontrou fortes resistências por parte dos países desenvolvidos (à exceção da França), Estados Unidos à frente, sob a argumentação de que o esforço prioritário deveria ser voltado para a reconstrução européia e asiática ${ }^{39}$ e que já havia sido criado, pela Conferência de Chapultepec em 1945, um Conselho Interamericano Econômico e Social dentro da Organização dos Estados Americanos (OEA), cujas funções a CEPAL viria duplicar. Segundo Pollock (1978: 61), o principal óbice era o temor dos norte-americanos de que o novo órgão (cujo Secretário Executivo seria designado pelo Secretário Geral da ONU) desafiasse sua hegemonia, que, dentro da OEA, era incontestável. Ademais, a OEA tinha (e tem) sede em Washington, e muitos dos representantes latino-americanos eram também embaixadores de seus países junto aos EUA. No entanto, as negociações evoluíram para a criação de um comitê ad hoc para estudar a necessidade e viabilidade da Comissão - é preciso observar que a América Latina tinha 20 dos 51 membros da ONU na época.

Ao fim de intensos debates e um intrincado processo de articulações políticas durante a reunião da Assembléia Geral da ONU de 1947 e do Conselho Econômico e Social do ano seguinte, foi aprovada, por este último, a emenda que criava a CEPAL, em 25 de fevereiro de 1948, com sede em Santiago do Chile. Seu primeiro Secretário Executivo foi o mexicano Gustavo Martínez Cabañas, sendo países membros a Argentina, Brasil, Colômbia, Costa Rica, Cuba, Chile, Equador, Estados Unidos, França, Guatemala, Haiti, Honduras, México, Nicarágua, Holanda, Panamá, Paraguai, Peru, Grã-Bretanha, República Dominicana, Uruguai e Venezuela. O organograma da instituição pode ser encontrado no manual das Nações Unidas (1962: 8) "Las Naciones Unidas y la América Latina".

A primeira reunião da CEPAL ocorreu em junho de 1948, em Santiago do Chile. O staff técnico da CEPAL, neste primeiro ano, era de cerca de dez pessoas e a primeira tarefa que lhe foi proposta foi a de reunir dados estatísticos sobre a região (inclusive, é de se notar, sobre termos de troca), dados estes escassos, dispersos e de má qualidade. Para alguns países, não se sabia nem mesmo o tamanho de sua população com exatidão.

Prebisch se incorporou à CEPAL em fevereiro de 1949. Santa Cruz (1985: 39) afirma que já então a intenção era entregar-lhe a direção da CEPAL, o que não se concretizou devido a resistências na cúpula da ONU. Na segunda reunião, em junho do ano seguinte, em Havana, foi apresentado o "Estudio Económico de América Latina - 1948", o primeiro da série, e de caráter quase exclusivamente descritivo ${ }^{40}$. Nesta mesma reunião foi entregue oficialmente o primeiro trabalho de Prebisch na CEPAL, intitulado "El desarrollo económico

\footnotetext{
${ }^{39}$ Em 1946 haviam sido criadas duas Comissões Econômicas Regionais, uma para a Europa e outra para a Ásia e Extremo Oriente.

${ }^{40}$ Hodara (1987b: 39-63) faz uma interessante comparação entre os Estudios de 1948 e 1949.
} 
de América Latina y sus principales problemas" (Prebisch 1962), e significativamente cognominado por Hirschman (1963) de "manifesto da CEPAL". O texto não difere muito, em seu conteúdo teórico e nas proposições de política econômica, e mesmo na forma da argumentação, do estudo econômico de 1949, objeto de nosso exame. Difere bastante, no entanto, por seu tom polêmico, engajado, que transparece desde o primeiro parágrafo. Furtado traduziu para o português e publicou o texto na Revista Brasileira de Economia de setembro de 1949, obtendo, segundo ele próprio, uma repercussão sem precedentes no Brasil.

O "Estudio Económico de América Latina - 1949" já foi preparado sob a orientação de Prebisch, então diretor do Centro de Pesquisas, e consta de cinco capítulos teóricos, redigidos por ele, de estudos mais descritivos de quatro países (Argentina, Brasil, Chile e México) e de uma análise conjuntural da situação econômica latino-americana. O trabalho foi exposto na conferência de Montevidéu em maio de 1950, no terceiro período de sessões da CEPAL. Nesta reunião foi aprovada uma resolução que veio a ser chamada o Decálogo do Desenvolvimento Econômico, que incorporava o espírito do Estudio - 1949, ao dar prioridade ao desenvolvimento, incentivar a planificação e reconhecer, implicitamente, a necessidade da ação dos governos latino-americanos.

A CEPAL se constituiu, a partir daí, num centro ideológico (em sentido amplo) irradiador da doutrina industrialista e, por isto mesmo, num foro político latino-americano. Ou, na observação ferina de Hodara (1987a: 391): Prebisch forneceu aos governos latinoamericanos "instâncias institucionais para assumir posições mancomunadamente ante os EUA, para além da denúncia trivial ou das emoções anti-americanas que o aprismo, o peronismo e o agrarismo cardenista implantaram na cultura política da área..." ${ }^{41}$.

Após a conferência de Montevidéu, Prebisch assumiu a Secretaria Executiva da CEPAL, cargo que ocupou até 1963. Nesse período exerceu uma liderança carismática e incontestável. Esta capacidade de liderança, sua oratória segura e ordenada ${ }^{42}$, sua disponibilidade para escutar e o círculo de técnicos capazes que Prebisch soube reunir e motivar foram fundamentais para o sucesso da instituição. A equipe contava, entre outros, com Celso Furtado, Jorge Ahumada, Aníbal Pinto, Cristóbal Lara, José A. Mayobre, Manuel Balboa, José Medina Echavarria, Victor Urquidi, David Pollock e Louis Swenson. "Don Raúl" impôs à CEPAL uma "monarquia paternalista" (Hodara 1987a: 383), extremamente funcional, no início, mas também parcialmente responsável, segundo os analistas, pelo processo entrópico em que entrou a instituição, na década de 1960.

Em maio de 1951, na conferência do México, foi apresentado o documento, redigido por Prebisch, "Problemas teóricos y prácticos del crecimiento económico" (CEPAL 1952). Furtado (1985) o considera a apresentação mais completa do pensamento cepalino. A

\footnotetext{
${ }^{41}$ V. tb. Pollock (1987: 368).

${ }^{42}$ Cf. Furtado (1985: 122) e Hodara (1987a: 388).
} 
escolha do Estudio - e não deste último texto - como objeto de nossa análise prende-se ao fato de o trabalho de 1949 ser uma manifestação institucional, aprovada pela Assembléia da CEPAL, sendo, por este motivo, mais significativa que as manifestações pessoais de Prebisch.

O ato de criação da CEPAL previa uma decisão ratificadora de sua existência três anos depois. Por esta época, depois da nomeação de Prebisch e em vista dos rumos que tomava a teorização cepalina, crescia a resistência do governo norte-americano à Comissão, amplificada pelo não-alinhamento da CEPAL na questão Leste-Oeste, numa época de auge da guerra fria. O Departamento de Estado dos EUA pressionava as chancelarias latinoamericanas para que a Assembléia da CEPAL recomendasse ao Conselho Econômico e Social da ONU sua dissolução, dando por encerrados os trabalhos. O meio encontrado foi o de transformar o Conselho Econômico e Social da OEA em órgão regional da ONU, substituindo a CEPAL. Esta proposta foi apresentada na conferência do México, citada acima. A maioria dos representantes latino-americanos, sem uma posição firme de seus governos, não se dispunha a enfrentar os norte-americanos. A manutenção da CEPAL só foi obtida, segundo Santa Cruz (1985: 42) graças a um telegrama de Getúlio Vargas, pelo peso que teve sua intervenção pessoal. No entanto, pelo relato que faz Furtado (1985: 122) de um encontro entre Prebisch e Vargas depois da conferência, já no Rio de Janeiro, este último até então não tinha conhecimento do teor dos trabalhos da CEPAL. A continuidade da instituição foi sacramentada por um parecer do comitê ad hoc (presidido por Santa Cruz) para análise do futuro das Comissões Econômicas Regionais, no Conselho Econômico e Social da ONU, ratificado pela Assembléia Geral em setembro de 1951.

\section{II.6- $\underline{\text { Repercussão }} \underline{\text { e críticas }}$}

A repercussão imediata dos primeiros textos cepalinos, segundo Furtado (1985: 101-3) foi limitada na América Latina. Apenas no Brasil, Chile, América Central e Cuba a primeira reação foi positiva. A mais longo prazo, sua influência foi profunda em toda a região. Hodara chega mesmo a falar em "revolução paradigmática" e na formação de uma "semiótica do desenvolvimento". Seja como for, Prebisch, além de chamar a atenção internacional para o problema do subdesenvolvimento, inaugurou uma nova forma de encarálo (e encaminhá-lo), acentuando a questão das relações comerciais com o centro, consideradas assimétricas. Este tema desde então figurou com proeminência no discurso econômico-político dos governos da região, até ser substituído, em tempos recentes, pelo discurso de orientação neo-liberal, com ênfase no atraso tecnológico. 
Os primeiros textos foram complementados por outros, versando sobre industrialização, programação econômica, comércio internacional, inflação, integração econômica, estudos setoriais e por países, distribuição de renda, dimensão social do desenvolvimento econômico etc. ${ }^{43}$. Pelo menos um destes textos deve ser destacado: trata-se do artigo "Commercial policies in the underdeveloped countries" (Prebisch 1959), apresentado na reunião anual da American Economic Association realizada em dezembro de 1958. Um veículo difusor das idéias cepalinas foi o Programa de Treinamento em Problemas do Desenvolvimento Econômico, criado em 1952, em Santiago do Chile, e que depois se estendeu também a outros países. Por este curso passaram muitos formuladores de política econômica da América Latina ${ }^{44}$.

Quanto à recepção no exterior, Pollock (1987: 68) descreve a reação, extremamente negativa, por parte da classe empresarial norte-americana, que sentia seus interesses na América Latina ameaçados pela proposta industrialista e pela defesa do que eles consideravam um grau excessivo de intervenção do governo na economia. O governo norteamericano reagiu no mesmo diapasão, situação que só se modificou, mesmo assim transitoriamente, no governo Kennedy, com a Aliança para o Progresso (1961). Arthur Schlesinger Jr., um de seus criadores, testemunha: "em suas idéias, a Aliança para o Progresso foi essencialmente um produto latino-americano, que surgiu de Raúl Prebisch, da Argentina, e da Comissão Econômica para a América Latina das Nações Unidas..." 45.

O ponto alto da Aliança foi a Reunião Extraordinária do Conselho Econômico e Social da OEA (conferência de Punta del Este), em 1961. Nela foram tomadas resoluções objetivando o aumento do nível de vida na região e melhora da distribuição de renda, através da diversificação da produção, aceleração da industrialização e produção interna de bens de capital, reforma agrária, redução do analfabetismo etc. Cardoso (1977: 30) observa que, embora aceitando em certa medida as críticas cepalinas, a Aliança retira sua ênfase nas relações internacionais e acentua os obstáculos internos ao desenvolvimento. Ainda assim, os resultados práticos obtidos foram parcos, e a morte de Kennedy apressou o fim da Aliança.

A recepção da academia à teoria cepalina foi, de modo geral, muito negativa. Jacob Viner (1951), em conferências realizadas no Rio de Janeiro, faz uma série de críticas, centrando fogo nos conceitos de centro e periferia e, em particular, na identificação entre agricultura e pobreza - e entre industrialização e desenvolvimento. O autor lembra os contraexemplos da Dinamarca, Nova Zelândia, Califórnia, Iowa, Nebraska etc.; e do lado dos industrializados, Itália e Espanha. Contesta também a afirmação de que o progresso técnico no setor industrial seja necessariamente mais rápido que no setor agrícola. Argumenta ainda que a população agrícola aufere rendas não-mensuráveis (porque não-monetárias), enquanto a

\footnotetext{
${ }^{43}$ Uma lista destas publicações de 1948 a 1967 encontra-se em CEPAL (1970: 279-303).

${ }^{44}$ Cf. Furtado (1985: 136).

${ }^{45}$ Cf. Pollock (1978: 73).
} 
urbana tem "rendas negativas" correspondentes aos maiores custos de transporte, custo da educação técnica etc. Estes fatores distorceriam as estatísticas em desfavor da agricultura. Quanto à tendência à deterioração dos termos de troca, alega que ela não implica necessariamente redução do bem-estar da periferia, já que a produtividade do setor exportador e o volume das exportações podem estar aumentando. Haberler (1964) acrescenta que variações do bem-estar seriam mais bem captadas pela relação de troca fatorial simples (relação de troca multiplicada pela produtividade das exportações da periferia).

Várias críticas foram feitas às séries de preços utilizadas para comprovar empiricamente a piora dos termos de troca. Para Viner, as séries de preços muito longas seriam viesadas, por não mensurarem a melhoria da qualidade dos produtos, melhoria esta mais marcada nos produtos industriais, e por desconhecerem as mudanças nas pautas de exportação e importação e criação de novos produtos. Esta crítica foi retomada por praticamente todos os analistas posteriores. Ellsworth (1956) agrega que a série de preços de importação da Grã-Bretanha (usada pela CEPAL como proxy dos preços de produtos exportados pela periferia) era calculada em termos CIF, enquanto os preços de produtos exportados pela Grã-Bretanha eram preços FOB. Dada a redução secular do custo de transportes, a série de termos de troca obtida a partir destes dados superestimava a deterioração, do ponto de vista da periferia.

A questão do estabelecimento de uma tendência secular dos termos de troca foi a que mais chamou a atenção dos críticos, dando origem a uma já extensa literatura, que inclui, entre outros, Haberler (1964), Baldwin (1952), Myint (1954), Meier (1958), Morgan (1959), Kindleberger (1956; 1958), Bhagwati (1960), Hyde (1963), Kaldor (1963), Powelson (1970), Guzmán (1976: 228-246), Spraos (1980; 1983), Sarkar (1986) e Diakosavvas e Scandizzo (1991) ${ }^{46}$.

Apresentamos, a seguir, as observações de outros críticos importantes do pensamento cepalino, que não se limitam à discussão sobre termos de troca.

Rogge (1959) faz uma crítica no mesmo diapasão da de Viner. Liberal extremado, atribui o subdesenvolvimento principalmente à regulamentação e interferência excessiva do Estado na atividade econômica, à instabilidade política, que afasta o capital estrangeiro, e à herança colonial. Os desequilíbrios do balanço de pagamentos seriam causados pela inflação, aliada ao sistema de taxas fixas de câmbio.

Hirschman (1967), escrevendo em 1961, procura mostrar que o eixo condutor da doutrina da CEPAL ao longo dos anos foi uma atitude crítica e militante em relação ao centro, aliada à confiança na capacidade do Estado de resolver os problemas do subdesenvolvimento. E suas proposições de planificação se contraporiam, para este autor, à

\footnotetext{
${ }^{46}$ Este último artigo contém uma extensa bibliografia sobre termos de troca, remontando a Ricardo.
} 
tendência a improvisar característica dos latino-americanos, sendo "em certo sentido o equivalente do século XX para as constituições latino-americanas do século XIX" (Hirschman 1967: 27). Em sua avaliação mais geral, este autor atribui à teoria cepalina um caráter ideológico, o que, entretanto, por si só não a invalida. Tão somente dificulta sua aceitação em meios intelectuais substancialmente diferentes, como o dos EUA. A posição defendida nesta dissertação é próxima tanto da de Hirschman quanto da de Flanders (1964a: 315) - que dá a entender que a CEPAL deseja a industrialização per se - como se verá no capítulo IV.

Frankenhoff (1962) faz uma revisão francamente favorável da obra de Prebisch. A crítica provinda do campo liberal enfatiza o aspecto estatizante do projeto cepalino. Este autor procura enfraquecer esta crítica, citando passagens em que Prebisch reconhece a importância inclusive de empresas estrangeiras.

Há também uma série de análises que focalizam menos o aspecto doutrinário e mais os pontos teóricos levantados pela CEPAL.

Baer (1962) estabelece que Prebisch não faz uma crítica interna à teoria clássica do comércio internacional, que demonstra as vantagens do comércio para todos os participantes num contexto estático. Prebisch apenas chama a atenção para a progressiva redução das vantagens do comércio (e da especialização) do ponto de vista da periferia se se considera certas alterações na demanda ao longo do tempo, em favor dos produtos industrializados, e os efeitos da elevação da produtividade, num contexto em que os mercados de fatores e de produtos do centro se afastam do padrão de concorrência perfeita.

Flanders (1964a) observa que as proposições de Prebisch não são no sentido da autarquia da América Latina, mas da mudança da composição das importações (de bens de consumo para bens de capital) de modo a possibilitar a industrialização. Faz também algumas críticas aos argumentos de Prebisch:

a) O efeito de tarifas protecionistas no sentido de impedir a deterioração é pequeno, porque os produtos exportáveis pelo centro são demandados majoritariamente pelo próprio centro, e não pela periferia. Portanto, seus preços são mais influenciados por variações na demanda cêntrica que na demanda periférica por estes produtos. Mais ainda: o próprio Prebisch baseia o argumento da deterioração na inflexibilidade para baixo dos preços e salários no centro. Logo, uma redução na demanda de produtos industrializados (devido ao protecionismo) não melhoraria os termos de troca.

b) O argumento sobre a deterioração envolvendo a "má distribuição dos frutos do progresso técnico" (caracterizado no próximo capítulo como o argumento principal do Estudio) envolve uma aplicação ingênua e falaciosa do teorema da igualação internacional dos preços de fatores. Ingênua porque desconhece as restrições à aplicação prática deste 
teorema, que exigiria, num modelo de dois países, dois fatores e duas mercadorias, que ambos os países produzissem as duas mercadorias. Ora, não é este o caso entre centro e periferia. E é uma aplicação falaciosa porque supõe implicitamente a existência de um só fator, o trabalho, e neste caso não poderiam surgir diferenças na remuneração do fator, com comércio ou sem ele.

c) $\mathrm{O}$ argumento da deterioração supõe também implicitamente que o progresso técnico simplesmente ocorre, desconsiderando os custos de pesquisa e desenvolvimento, incorridos principalmente nos centros. Só assim se poderia entender a necessidade de distribuição equitativa dos "frutos do progresso técnico".

d) A versão ciclo do argumento da deterioração (também desenvolvida no próximo capítulo) assenta-se sobre a hipótese de que os salários nominais (e reais) no centro são inflexíveis para baixo. O ônus do ajustamento à redução global da demanda durante a crise recairia, assim, sobre a periferia, através da deterioração. Ocorre que o ajuste se dá também no centro, através do desemprego em massa.

Flanders faz ainda outras críticas, que deixamos de apresentar, por se referirem exclusivamente à argumentação do artigo "Commercial policies in the underdeveloped countries" (Prebisch 1959).

Octávio Rodríguez, um dos mais importantes analistas do pensamento cepalino, reconhece a ele uma certa coerência interna, chegando a caracterizá-lo como o esboço de uma teoria da economia periférica (1981: 233). Isto acontece apesar da dispersão desse pensamento por um grande número de documentos, visando, cada um, objetivos específicos.

Este autor coloca como hipóteses básicas da teorização cepalina a concepção do sistema centro-periferia e as características estruturais atribuídas por Prebisch às economias periféricas: a heterogeneidade (grande diferencial de produtividade entre o setor primário-exportador e o de consumo interno) e a especialização (o crescimento praticamente se limita ao setor exportador, e este a alguns poucos bens primários). Destas características deduzem-se três tendências: ao desemprego estrutural, ao desequilíbrio do balanço de pagamentos e à deterioração dos termos de troca. As três redundam no desenvolvimento desigual do sistema centro-periferia. O destaque concedido à reprodução, por este mecanismo, das disparidades iniciais é que permite caracterizar a teorização cepalina como estruturalista (v. Rodríguez 1981: 142-5; 250-2). Este seria o traço de maior originalidade desta corrente de pensamento.

Rodríguez, numa crítica de corte marxista, reclama da ausência, na explicação do processo de industrialização e transformação estrutural, das relações sociais características deste processo. As relações capitalistas de produção estão implícitas, e não se analisa o 
caráter que tais relações assumem no interior das formações periféricas. Critica também a ausência de referência às condições de acumulação em escala mundial, que influiriam sobre as possibilidades de crescimento e diversificação (ou não) do pólo periférico, juntamente com os fatores estruturais aventados pela CEPAL.

No plano sociológico, Rodríguez identifica no pensamento da CEPAL um projeto sócio-político. As transformações descritas e propugnadas pela instituição promovem, sob uma aparência de neutralidade, os interesses das burguesias industriais latino-americanas. Além disto, o projeto cepalino "pretende resguardar os interesses das camadas médias, dos setores operários e, de um modo geral, dos amplos grupos despossuídos" (Rodríguez 1981: 23). E finalmente, o projeto contempla os interesses dos estamentos ligados ao aparato do Estado, ao propor a ampliação de suas funções e do grau de intervenção, e ao concebê-lo como instituição acima das classes sociais, apta, por isto mesmo, a dirimir os conflitos entre elas. Estas características fundamentam sua afirmação de que "o pensamento da CEPAL dos anos 1950 constitui a forma mais abstrata e, ao mesmo tempo, mais desenvolvida e coerente de um ponto de vista analítico das ideologias de caráter populista" (Rodríguez 1981: 270 grifo nosso). Prebisch (1981: 11-12) rejeita esta interpretação, afirmando que não havia uma resposta clara, nos escritos cepalinos, à questão de a quem eles favoreciam.

Quanto a nós, acreditamos que Prebisch se serve da ideologia populista para seus próprios objetivos, sem se confundir com ela. A evolução posterior de seu pensamento, que revela uma crítica cada vez mais radical às políticas imediatistas e ao próprio capitalismo periférico, permite esta ilação.

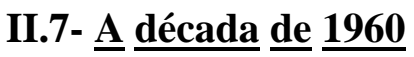

Nesta década aumenta, dentro da CEPAL, a preocupação com a integração dos aspectos sociais e políticos na explicação do processo de desenvolvimento. Acentua-se o reformismo das posições cepalinas, com ênfase nas transformações estruturais, em particular a reforma agrária e a redistribuição da renda. Ganham ênfase também as proposições de políticas trabalhista e social, visando minorar os problemas provocados pelo processo de industrialização e urbanização. No âmbito das relações comerciais internacionais, várias propostas para sua reformulação são feitas, como meio de compensar a deterioração dos termos de troca, com destaque para a proposta de criação de um mercado comum latinoamericano ${ }^{47}$. Não obstante, esta década representou um período de declínio da CEPAL, em que seus textos não mais produziram o impacto da novidade, e sua ação retornou aos estreitos

${ }^{47}$ V. Rodriguez (1981: 26; 271). 
limites característicos de uma instituição burocrática intergovernamental. Alguns motivos têm sido apontados para a decadência teórica e perda de importância da CEPAL ${ }^{48}$ :

a) A restrição à liberdade criativa dos técnicos da CEPAL, seja pelo excessivo centralismo de Prebisch (que não permitiu a publicação de um trabalho de Noyola e Furtado sobre o México) ou pela própria situação institucional, que impedia a abordagem de problemas concretos dos países-membros, que pudesse ferir susceptibilidades. Furtado (1985: 183) se queixa em particular da limitação à publicação de artigos assinados pelos técnicos.

b) O fato de ser aceita pelos EUA, nos marcos da Aliança para o Progresso, privou a CEPAL de um interlocutor que, embora hostil, ajudava a orientar seu discurso. Assim, a instituição voltou-se para si mesma e para assuntos internos à América Latina. Registre-se também que Prebisch já se havia voltado para a questão do curto prazo, tendo criado um plano de estabilização para a Argentina, após a queda de Perón (dito "Plano Prebisch" -1955). Este plano priorizava o setor agrícola, desvalorizava o peso e buscava uma solução intermediária para o problema do investimento estrangeiro direto. Tais diretrizes contrastavam em muito com as idéias defendidas por Prebisch no âmbito da CEPAL, o que não deixou de ter reflexos sobre a instituição ${ }^{49}$.

c) A ruptura das alianças de tipo populista, o gradativo esgotamento do modelo de crescimento baseado na substituição de importações e os problemas a ele associados (desemprego, concentração da renda, crescimento do endividamento externo etc.) contribuíram para um clima de pessimismo, com a perda das perspectivas de viabilidade que o projeto cepalino possuía na década anterior.

d) A importância adquirida por outros órgãos interamericanos, também sob o impulso da Aliança para o Progresso, como o Banco Interamericano de Desenvolvimento (BID), a OEA e a Associação Latino-Americana de Livre Comércio (ALALC).

e) O surgimento, em 1964, da Conferência das Nações Unidas sobre Desenvolvimento e Comércio (UNCTAD), através da qual Prebisch, seu criador e primeiro Secretário-Geral, procurou estender sua atuação a toda a periferia, pregando o reordenamento das relações comerciais e financeiras com o centro. Este foro terceiro-mundista, embora não tenha apresentado resultados práticos apreciáveis, teve o efeito de eclipsar a CEPAL enquanto órgão político.

A estes fatores acrescentamos um componente propriamente retórico, qual seja, o de que o discurso cepalino havia perdido, por esta época, a coerência e o caráter programático dos primeiros escritos. O próprio Prebisch ${ }^{50}$, fazendo um retrospecto, destaca

\footnotetext{
${ }^{48}$ V. Pollock (1978: 76-7), Rodríguez (1981: 273-4), Furtado (1985: 182-3) e Hodara (1987a: 388; 391).

${ }^{49}$ Cf. Furtado (1985: 182).

${ }^{50}$ Prebisch (1987: 19-21).
} 
os três pontos que mais o interessavam no período 1958-1963: o problema do esgotamento do processo de substituição de importações (falando mesmo na necessidade de redução de tarifas de importação), a distribuição de renda e a inflação (recomendando políticas próximas das do FMI). Esta ampliação dos interesses de Prebisch teria necessariamente que tornar seu discurso mais hesitante e, portanto, menos eficaz. Por esta época também surgiu, na CEPAL, a idéia da tendência à estagnação estrutural. Esta idéia, se tomada a sério, não permite apontar alternativas de política econômica, ou pelo menos é incompatível ${ }^{51}$ com a manutenção do sistema capitalista, ou seja, incompatível com uma premissa admitida pela CEPAL.

\section{II.8- Observação}

A identificação do ambiente intelectual e político latino-americano, da conjuntura econômica, dos possíveis antecedentes teóricos da CEPAL, das vicissitudes institucionais deste órgão, das características pessoais de Prebisch, em suma, do contorno histórico da teoria cepalina, conquanto seja importante para sua compreensão, não a esgota. Fosse este o caso, esta dissertação poderia terminar neste ponto. No entanto, aí está Fernando Henrique Cardoso, com sua sensibilidade de sociólogo, a defender a "originalidade da cópia", e a defender-nos dos determinismos estritos, tacanhos. A nós importa não tanto mostrar as formas através das quais este contorno se materializa nos escritos cepalinos, tarefa à qual muitos já se dedicaram - entre outros, o próprio Cardoso (1977), Love (1978, 1980, 1987), Rodríguez (1981), Furtado (1985) e Hodara (1987 a e b). Importa-nos (e esta é a especificidade de nosso enfoque), tomando como dados históricos os escritos cepalinos, explorar as formas pelas quais Prebisch procura transmitir suas convicções a seu auditório, formas estas de sua livre criação. Tais formas, como procuraremos mostrar no cap. IV, são elemento importante na explicação do sucesso do processo persuasivo que Prebisch e CEPAL levaram a cabo.

\footnotetext{
${ }^{51}$ No sentido de Perelman - v. cap. I.
} 


\section{III- TEXTO}

Para conveniência do leitor e com vistas a uma maior fidelidade ao original, optamos por fazer uma apresentação dos argumentos do Estudio na sequência em que aparecem no próprio texto, permitindo observar seu encadeamento, e deixando para o capítulo seguinte a classificação de seus diversos tipos e o comentário mais detalhado.

O primeiro capítulo se intitula "Propagación del progreso técnico a la América Latina y problemas que plantea". Prebisch começa por dar um quadro geral da economia mundial, destacando os aspectos que lhe interessam, introduzindo a dicotomia centro/periferia e frisando que o desenvolvimento de um setor industrial nesta última é uma necessidade lógica, que os fatos já começavam a confirmar. Afirma que, da revolução industrial à primeira guerra, a difusão do progresso técnico do centro se limitou ao setor exportador da periferia. Esta primeira fase não poderia ser a definitiva, "pues quedaba en cierto modo al margen de ella [da economia mundial] el amplísimo campo de la periferia, con enormes posibilidades de asimilar el progreso técnico" (CEPAL 1950: 3). No período pósprimeira guerra e pós-depressão começa a segunda fase, durante a qual foi criado um setor industrial considerável na periferia.

Aqui se introduz um segundo argumento a favor da industrialização, embora substancialmente diferente, qual seja, o de que esta permite "compensar así, mediante el desarrollo desde dentro, la notória insuficiencia del impulso que desde fuera había estimulado hasta entonces la economia latinoamericana" (ibidem: 4 - grifo nosso). O raciocínio é teleológico: só se pode estabelecer uma insuficiência em relação a um padrão ideal de desenvolvimento. À necessidade lógica da industrialização da periferia se sobrepõe sua desejabilidade.

A seguir Prebisch volta à descrição, dividindo a América Latina em dois tipos econômicos básicos: um, formado pelas regiões de ocupação relativamente recente, organizada em bases capitalistas, e de terras férteis, nas quais houve forte progresso técnico (paradigma: Argentina); o outro, representado por regiões relativamente populosas e com uma agricultura de subsistência secular (paradigma: México). Nestas últimas, o progresso técnico na agricultura não é uma realidade, mas uma necessidade. Aqui, como se vê, o autor reassume o ponto de vista teleológico, que mantém em sua observação seguinte: o aumento de produtividade no setor primário cria um excedente populacional. "Se apela entonces a la industria y otras actividades, para absorber productivamente esa fuerza de trabajo" (ibidem: 4 - grifo nosso).

Terminada a descrição, retoma-se a chave da industrialização como uma necessidade lógica, inelutável: "Por la fuerza de las cosas, una proporción creciente de la 
población activa de la América Latina [...] irá desplazandose desde la agricultura hacia la industria..." (ibidem: 5). Segundo pensamos, esta rápida sucessão e alternância de pontos de vista característica de Prebisch é fator importante na explicação do poder persuasivo de seu discurso. O leitor é bombardeado com fatos e valores, invariavelmente ligados à inevitabilidade ou desejabilidade da industrialização, sendo que cada argumento isoladamente não tem a extensão e o vagar necessários ao surgimento da crítica. Muitas vezes eles sequer explicitam sua conclusão, o que só o contexto permite fazer.

Voltando ao texto: a seção seguinte traz uma digressão sobre a Argentina e o México, apresentando-os como dois casos distintos de desenvolvimento econômico, dois casos-limite que permitem circunscrever todos os demais. O peso do argumento está, no entanto, no "denominador comum" entre os dois: o progresso técnico (real ou virtual) na agricultura cria um excedente populacional. A conclusão, deixada ao leitor, é de que só a indústria permitiria absorvê-lo. A conclusão é tanto mais provável porquanto Prebisch afirma que, na Argentina, foi esta a solução histórica.

O autor prossegue a digressão histórica demonstrando as peculiaridades econômicas de México, Brasil, Cuba, Argentina etc. e apresentando dados de taxa de crescimento populacional, porcentagem da população ativa empregada na produção primária e exportações per capita nos países da América Latina (ibidem: 8). A conclusão, como no caso anterior, é única para toda a região: excetuado o caso da Venezuela, o aumento das exportações é insuficiente para absorver o crescimento da população mais o excedente populacional gerado pelo progresso técnico e ainda para atender às necessidades de importação que o desenvolvimento econômico traz consigo.

Este argumento, ao nosso ver, não termina aqui, podendo ser encaixado no modelo do "argumento de divisão" (v. seção IV.11 adiante). De fato, não interessa particularmente à CEPAL expor os problemas do setor externo da economia latinoamericana, mas propor um programa industrializador. Para este efeito, a economia é dividida em dois compartimentos estanques e mutuamente excludentes: o primário-exportador e o secundário. Assim, o crescimento industrial e o crescimento agrícola tornam-se as duas únicas fontes possíveis de desenvolvimento da periferia. Esta premissa é frequentemente apresentada de forma implícita. A segunda premissa é a de que o setor agrícola é incapaz de gerar desenvolvimento, porque o aumento de sua produtividade implica na geração de um excedente de oferta de mão-de-obra no setor primário, que impede a elevação dos salários, provoca deterioração dos termos de troca e desequilíbrio do balanço de pagamentos. Destas duas premissas conclui-se que a industrialização é condição necessária do desenvolvimento. A esta conclusão acrescenta-se uma premissa normativa, a de que o desenvolvimento é desejável. Prebisch não precisa enfatizar esta premissa, que faz parte dos valores de seu 
auditório. A conclusão final, o mais das vezes implícita, é também normativa: a industrialização é desejável.

De forma esquemática:

P1: ind. e/ou agric. de exportação $\Leftrightarrow$ desenvolvimento

P2: agric. de exportação $\Rightarrow$ não desenvolvimento

C1: industrialização $\Leftrightarrow$ desenvolvimento

P3: desenvolvimento é desejável

C2: industrialização é desejável

Os argumentos que se conformam a este modelo estão espalhados ao longo do texto, e nenhum deles reproduz o modelo fielmente. Via de regra, eles contêm apenas algumas das proposições expostas acima, deixando ao leitor a tarefa de completar o raciocínio.

A seção seguinte vai na mesma linha, apenas acrescentando ao argumento empírico uma fundamentação teórica, conduzindo à conclusão de que o crescimento econômico (baseado no setor primário, bem entendido) leva inevitavelmente ao desequilíbrio do balanço de pagamentos e, internamente, ao excesso de oferta. Um aumento de produtividade exógeno na agricultura de consumo interno ou no setor exportador gera aumento da renda per capita e, por esta via, das importações per capita (efeito este magnificado pela elevação do coeficiente de importação) ${ }^{52}$. Sob a hipótese de que a demanda pelas exportações da periferia aumenta à mesma taxa que sua população - ou seja, que suas exportações per capita são constantes - produz-se um déficit crescente no balanço de pagamentos. O crescimento da renda decorrente do aumento de produtividade corresponde a um aumento do mesmo montante na oferta global mas não na demanda, já que uma parte do incremento da renda é gasta em importações. Portanto, gera-se um excesso de oferta.

O primeiro capítulo do Estudio se encerra com uma argumentação que conclui pela inevitabilidade do desenvolvimento do setor secundário (e terciário) na periferia. A primeira fundamentação desta afirmativa é de ordem empírica: "Es un hecho bien sabido que en un estado de técnica primitiva, la proporción de gente ocupada en la agricultura y demás ramas de la producción primária es muy alta, y que a la medida que la técnica progresa, esta

${ }^{52}$ Porque a demanda por importações é elástica em relação à renda e porque o progresso técnico implica em aumento das importações de bens de capital. 
proporción va disminuyendo, mientras aumenta la importancia relativa de la población ocupada en la industria, el comercio, los transportes y los servicios" (CEPAL 1950: 12-13 grifo nosso). Como ilustração desta proposição, o autor cita dados referentes aos EUA e à Argentina.

O segundo argumento é do tipo a contrariu senso: se houvesse progresso técnico na produção primária da periferia sem redistribuição da população ativa entre setores, haveria um excedente de produtos primários que não poderiam ser elaborados, transportados e distribuídos. Haveria um excesso de oferta de mão-de-obra na produção primária e excesso de demanda de mão-de-obra nos outros setores em nível mundial. Isto é inadmissível "tanto desde el punto de vista lógico como desde el experimental" (ibidem: 14). Portanto, o efeito do aumento de produtividade no setor primário da periferia é o crescimento dos demais setores, no centro ou na periferia. Para tal crescimento se dar no centro, seria necessário que houvesse absoluta mobilidade da mão-de-obra periférica. Como não há tal mobilidade, o crescimento tem de se dar necessariamente na periferia.

O capítulo II do Estudio, intitulado "Debilitamiento de la capacidad para importar de la América Latina en el último cuarto de siglo", pretende apresentar a comprovação empírica das teses de Prebisch, particularmente a tendência à deterioração dos termos de troca ${ }^{53}$. Logo no começo do capítulo (CEPAL 1950: 16) o autor recorre pela segunda vez ao argumento de divisão. A tendência ao déficit do balanço de pagamentos pode ser evitada de duas formas: ou aumentando-se a capacidade para importar ou reduzindo-se o coeficiente de importações. Nas onze páginas seguintes, demonstra-se que, de 1925 a 1949, a primeira alternativa não foi realizada. A conclusão, implícita, é a de que há necessidade de reduzir o coeficiente de importações - através do processo de substituição de importações, por suposto. O recurso aos dados empíricos é longo e minucioso: são apresentados três gráficos e cinco tabelas, contendo dados sobre a evolução das exportações per capita da América Latina e dos termos de troca neste período, englobando o comércio América Latinaresto do mundo, América Latina-EUA e América Latina-Reino Unido.

Segue-se uma outra seção estatística, onde, da correlação positiva entre termos de troca e coeficiente de importação do centro de produtos primários, extrai-se uma relação de causalidade: "el efecto de este mejoramiento [piora dos termos de troca, nos anos 30, do ponto de vista periférico] ha consistido sencillamente en permitir que los Estados Unidos importen productos latinoamericanos en proporción mucho menor que antes de disminuir su ingreso monetário..." (ibidem: 28). Os dados empíricos aduzidos em favor desta tese referemse ao comércio EUA-América Latina, Reino Unido-América Latina, EUA-resto do mundo e

\footnotetext{
${ }^{53}$ Seguindo o uso de Prebisch, definimos os termos de troca neste trabalho sempre do ponto de vista da periferia, como a relação entre o preço das exportações da periferia para o centro e o preço das exportações do centro para a periferia. Portanto, um aumento desta relação expressa uma melhoria dos termos de troca.
} 
Reino Unido-resto do mundo, expostos em quatro tabelas e um gráfico. A consequência da piora dos termos de troca e da redução do coeficiente de importação do centro foi a redução do coeficiente de importação da América Latina, de modo a evitar o desequilíbrio do balanço de pagamentos. Tal solução, contudo, não poderia deixar de ser provisória pois, como argumentado mais acima, o próprio processo de desenvolvimento periférico induz ao desequilíbrio nas contas externas.

A principal conclusão que Prebisch extrai de todo este raciocínio baseia-se, surpreendentemente, na forte correlação entre as exportações da periferia e a renda do centro, e independe do restante do argumento. Tal inferência é de que o crescimento das exportações periféricas (e, portanto, acrescentamos, o ímpeto do modelo de crescimento hacia afuera) está limitado pelo crescimento da renda do centro. Isto implica que o modelo extrovertido de desenvolvimento é incapaz de superar a dicotomia centro-periferia.

O autor prossegue examinando as consequências que a transferência do núcleo do centro do Reino Unido para os EUA, neste século, teve sobre as possibilidades de desenvolvimento da periferia. Tal mudança teve como implicação reduzir o coeficiente de importação do centro, sendo a economia americana muito mais fechada que a inglesa.

Um hipotético desenvolvimento autônomo da periferia (crescimento da renda) gera um aumento das importações que esta faz do centro, provocando o crescimento da renda e da demanda do centro e, por esta via, das exportações da periferia para o centro. Ora, a defasagem entre o aumento inicial das importações da periferia e o aumento de suas exportações é função inversa do coeficiente de importação do centro. Assim, a mudança do centro cíclico implica que o crescimento autônomo da periferia (através de exportações, digase) traria consigo uma tendência ao déficit no balanço de pagamentos. Tal argumento teórico é apresentado em duas versões - com e sem pleno-emprego dos fatores no centro acompanhadas de exemplos numéricos. A conclusão apresentada é a de que era necessário reduzir, em resposta às dificuldades, o coeficiente de importação da periferia, o que já vinha ocorrendo. Inviabilizava-se, desta forma, o sistema multilateral característico do padrão-ouro, e favorecia-se as relações comerciais bilaterais. $\quad$ O terceiro capítulo do Estudio, "La propagación del progreso tecnico y los términos del intercambio", se dedica a explicar a tendência à deterioração dos termos de troca através da "relativa lentitud con que el desarrollo industrial en el mundo va absorbiendo el exceso real o potencial de la población activa dedicada a las actividades primarias" (CEPAL 1950: 48). Aqui se apresenta o que consideramos o argumento principal do Estudio.

Reza o argumento que, sendo o aumento de produtividade devido ao progresso técnico maior na indústria do que no setor primário, o preço dos produtos industrializados (exportados do centro para a periferia) deveria cair em relação ao dos produtos primários, que seguem a direção inversa. Ou seja, os termos de troca deveriam melhorar para a periferia. Se 
eles de fato pioram, isto é devido ao fato de que o centro retém para si os frutos de seu próprio progresso técnico e se apropria de parte do progresso técnico da periferia.

A explicação dada a este fenômeno é a seguinte: o progresso técnico no setor primário da periferia, a alta taxa de crescimento da oferta de mão-de-obra neste setor e a relativa imobilidade da mão-de-obra são responsáveis pela criação de um excedente de mãode-obra no setor primário da periferia, que, através da pressão baixista sobre os salários e, consequentemente, sobre os preços deste setor, permite ao centro se apropriar de parte dos frutos do progresso técnico periférico. A conclusão de todo este raciocínio é explícita: para evitar o excedente de mão-de-obra no setor primário (e assim evitar também a deterioração), há que se industrializar a periferia.

Segue-se uma segunda explicação para a piora dos termos de troca. Partindo-se novamente de um aumento autônomo da produção primária (e da renda periférica) tem-se um aumento menos que proporcional na demanda (mundial) de produtos industriais e, consequentemente, um aumento menos que proporcional na renda do centro e na demanda cêntrica de produtos primários ${ }^{54}$. Assim, os termos de troca, que são função direta da demanda cêntrica por produtos primários e inversa da oferta destes mesmos produtos, tendem a piorar. A partir disso, o autor afirma (no que constitui um outro argumento próindustrialização) que o crescimento industrial estimula o setor primário, mas a recíproca não é verdadeira, ou pelo menos não o é na mesma medida ${ }^{55}$.

Tal raciocínio leva a uma digressão histórica, na qual Prebisch afirma que, no século passado, o rápido desenvolvimento industrial no centro ("fator dinâmico") permitiu a absorção de parte da mão-de-obra liberada pelo seu próprio setor primário. Este fato, no entanto, não foi suficiente para evitar a emigração para a periferia, nem a tendência à deterioração. Com a Grande Depressão e o consequente amortecimento do fator dinâmico tradicional, a piora dos termos de troca torna-se mais pronunciada, exigindo a instauração de um novo fator dinâmico, a saber, o desenvolvimento industrial autônomo.

Uma segunda digressão procura levar em conta a heterogeneidade da própria periferia: países que entraram recentemente no mercado internacional, ao elevar a produtividade de seus setores primários, sem desenvolver um setor industrial para absorver o excedente de população ativa assim gerado, provocam deterioração dos termos de troca da periferia como um todo. Isto interfere com o argumento principal, pelo qual a industrialização da periferia ${ }^{56}$ impediria a deterioração. Ainda que haja queda dos termos de troca, Prebisch defende o aumento de produtividade da agricultura conjugado com a industrialização com

\footnotetext{
${ }^{54}$ Esta última passagem, do aumento da demanda mundial de produtos industriais para o aumento da demanda cêntrica de produtos primários, não é explicitada no texto.

${ }^{55}$ Um relatório do GATT de 1960, citado em Baer (1962: 214), chega praticamente aà mesma conclusão, a partir de dados empíricos referentes à década de 1950.

${ }^{56}$ Entenda-se, da periferia tradicional, já existente, ou, em outras palavras, da América Latina.
} 
base no raciocínio de que, mesmo que os frutos do progresso técnico na agricultura de exportação sejam totalmente transferidos para o centro, há um ganho líquido correspondente ao aumento de produtividade do setor primário não-exportador e ao montante da produção gerada pela parcela da população ativa que, se não houvesse industrialização, estaria desempregada.

Uma última digressão trata da teoria neoclássica do comércio internacional, considerada irrealista por supor a hipótese de mobilidade absoluta de fatores (sic) e produtos. Isto faz com que as conclusões desta teoria conflitem com a realidade, ao afirmar, por exemplo, que não pode haver diferencial permanente de produtividade entre países nem entre regiões, ou que o centro não retém os frutos de seu progresso técnico. Em sua revisão da teoria neoclássica, Prebisch dá um lugar importante ao estudo do ciclo econômico e sua influência sobre as relações econômicas entre centro e periferia. É o que Rodriguez (1981) denominou "versão ciclo" do argumento da deterioração, apresentada da seguinte forma: há uma assimetria no comportamento dos salários (e de "outras rendas") no centro durante o ciclo. Na fase crescente, os salários nominais crescem, embora menos que os preços. Na fase decrescente, os salários nominais caem, também menos que os preços. Supondo que haja um aumento líquido dos salários reais durante o ciclo ${ }^{57}$ maior que o aumento de produtividade (e, adicionalmente, que os outros componentes da renda sejam inflexíveis para baixo), a igualdade entre renda e oferta agregada exige que os termos de troca piorem para a periferia.

O quarto capítulo, "Contrastes y disparidades en el proceso de desarrollo económico", traça essencialmente uma comparação entre o processo de desenvolvimento dos países periféricos do século passado (dos quais o caso paradigmático é o dos EUA) e os deste século, em que é muito maior a disparidade entre centro e periferia e, portanto, a dificuldade em superá-la.

Nesta linha, com a retenção dos frutos do progresso técnico no centro, a maior capacidade de demanda e poupança se desenvolve só neste pólo do comércio internacional. Como a técnica industrial provém dele, e é adequada às suas condições, a periferia tem dificuldade em absorvê-la. Assim, por exemplo, a técnica cêntrica atual exige uma alta intensidade de capital. Só a alta renda per capita vigente no centro permite gerar a poupança necessária para financiar a adoção desta técnica. Em contraste, a poupança na América Latina é escassa relativamente às necessidades de poupança inerentes à técnica cêntrica, o que dificulta sua adoção.

Da mesma forma, a técnica cêntrica exige a produção em grande escala. A produtividade da periferia, muito baixa, não permite gerar demanda suficiente para absorver toda a produção. Isto dificulta, portanto, a adoção desta técnica. Com nenhum destes

${ }^{57}$ Tal aumento líquido é atribuído, em última análise, a "uma resistência muito grande à baixa de salários", na fase decrescente. 
problemas se defrontaram os países periféricos emergentes do século passado, pelo fato de não haver, ainda, um hiato muito grande em relação ao estado da técnica e da produtividade nos centros.

Uma outra comparação explícita entre os EUA e a América Latina diz respeito ao fato de que, no primeiro país, o desenvolvimento industrial, ao provocar êxodo rural e elevar os salários na agricultura, gerou a necessidade de elevar a produtividade agrícola. Já na América Latina, o progresso técnico é introduzido primeiramente no setor primário, formando um excedente de mão-de-obra que deprime os salários e reduz o preço dos produtos exportáveis, tornando necessária a industrialização. O problema é tanto mais sério porquanto falta à América Latina (mas não ao centro) uma indústria de bens de capital, que poderia compensar, ao menos parcialmente, o desemprego gerado pelo progresso técnico. A solução preconizada é a adoção de "uma política deliberada de desarrollo económico" (CEPAL 1950: 69). Por outro lado, a importação de bens de capital só é possível, dadas as restrições do balanço de pagamentos, com o aumento das exportações, o que só se pode fazer em detrimento dos termos de troca.

Ainda outro problema trazido pelo desenvolvimento tardio, segundo o autor, é o de que a tecnologia produzida no centro e importada pela periferia é adequada à proporção entre fatores vigente no centro. Assim, sua intensidade de capital é muito maior que a intensidade ótima para a periferia. Acresce que a inflação e as restrições à importação distorcem ainda mais a alocação de recursos, provocando sobreinvestimento nos setores por elas favorecidos. Neste ponto Prebisch faz um comentário marginal, no sentido de que tão necessário quanto o investimento em bens de capital é o adestramento e melhoria técnica da mão-de-obra.

Uma última desvantagem dos países periféricos diz respeito ao efeitodemonstração. Expostas aos padrões de consumo muito mais sofisticados do centro, as classes de maior renda da periferia tendem a imitá-los, forçando, por esta via, o aumento da participação do consumo na renda. Por outro lado, a absorção da técnica cêntrica exige a elevação da participação do investimento na renda, assim como tendem a elevar-se os gastos do governo, por um "efeito-demonstração" proveniente dos governos cêntricos. O conflito distributivo gerado por estes três fatores produz inflação, o que torna mais necessário o aumento de produtividade para acomodar tais tensões.

Prebisch conclui o capítulo defendendo a industrialização deliberada da periferia e o protecionismo, o que é justificado da seguinte maneira: a disparidade de renda e produtividade entre o Reino Unido e os países que no século XIX eram periféricos forçou-os a tomar medidas de estímulo e proteção às indústrias que pretendiam desenvolver. E o diferencial de produtividade e renda entre centro e periferia é, hoje, muito mais pronunciado do que naquela época. Logo, o protecionismo da América Latina é, a fortiori, justificado. 
O quinto e último capítulo da parte teórica do Estudio trata das "Consecuencias de los desniveles internacionales en los ingresos y en la productividad", centrando-se no conflito de interesses entre centro e periferia, que se manifesta em medidas protecionistas de ambos os lados.

O contínuo crescimento da produtividade, mais concentrado em alguns setores do centro, eleva os salários, inclusive para os setores que não participam desta melhora na técnica na mesma medida. Tais setores perdem, por este motivo, competitividade em relação aos setores análogos dos países periféricos. A solução consiste em instituir proteção tarifária e/ou subsídios. Prebisch usa como exemplo o subsídio à agricultura e a proteção tarifária nos EUA e Reino Unido. Estas medidas permitem aos centros manter ou mesmo aumentar o diferencial de renda em relação à periferia. Um exemplo adicional é o do consistente aumento de produtividade japonês, conjugado com baixos salários, que provocou nos demais países industriais uma reação protecionista.

O mesmo argumento é então, mutatis mutandis, aplicado à periferia. Esta se viu necessitada de estimular - i. e., proteger - sua indústria para absorver o excedente de população ativa, assim como o centro procura defender seus setores menos competitivos em relação à periferia. A proteção tem que ser, como é, maior nos países, como Cuba e Venezuela, onde é muito grande o diferencial de produtividade entre a atividade exportadora e as demais.

Desníveis de produtividade existem, conforme Prebisch constata, não só entre centro e periferia, mas entre os próprios países periféricos, embora menos marcados. Na América Latina, isto tem significado déficits nas balanças comerciais de alguns países com respeito aos demais, o que se tem procurado resolver através de acordos bilaterais. Ressalta o autor, porém, que tais acordos deveriam procurar incrementar o intercâmbio industrial entre os países, visando promover economias de escala.

Aqui terminamos a descrição da parte teórica do Estudio, cabendo agora sua interpretação e a análise dos mecanismos persuasórios envolvidos, cujo estudo, julgamos nós, ilumina o texto e ajuda a explicar sua ampla aceitação e longa permanência no cenário da teoria econômica latino-americana. 


\section{IV- ANÁLISE}

Este capítulo traz a análise retórica do Estudio, devendo-se ressaltar as premissas de que seu autor parte, compartilhadas por ele e seu auditório, e os dois procedimentos retóricos fundamentais do texto, quais sejam o uso da metáfora centroperiferia e do argumento de divisão. Observamos, retomando comentário feito no capítulo I, que a análise retórica, quando aplicada a um discurso particular, assume necessariamente um caráter crítico, já que revela os procedimentos persuasórios empregados pelo orador. Por isto mesmo torna-se necessária a ressalva de que não pretendemos isolar o discurso prebischiano como exemplo cabal de discurso "retórico", artificioso e emocional. Para nós, como para Perelman, todo discurso não-formal não pode deixar de ser retórico, o que não tem, necessariamente, uma conotação negativa.

\section{IV.1- $\underline{\text { As condições prévias da argumentação }}$}

Não nos deteremos por muito tempo neste ponto, visto que nosso objeto de estudo é um discurso situado no passado, portanto um discurso que se efetivou. Neste caso é trivial afirmar que as condições prévias estavam dadas. $\mathrm{O}$ exame de tais condições se reveste de maior importância, no entanto, se o objeto de estudo for, por exemplo, o debate econômico em geral.

Perelman lista quatro destas condições prévias, quais sejam: a) a existência de uma linguagem comum; b) o desejo do orador de se comunicar; c) o fato de o orador valorizar a opinião do auditório; e d) a disposição do auditório de ouvir o orador.

Sobre a exigência de uma linguagem comum, há que notar a opção de Prebisch pela não formalização de seus argumentos. A linguagem discursiva lhe permite atingir um público não-acadêmico, como é, em grande medida, seu auditório-alvo (ver seção IV.3 adiante). A condição b) é plenamente preenchida, como o comprovam a própria existência do Estudio, e, dentro dele, o uso de uma linguagem de convicção, que visa transmitir ao leitor as opiniões e valores do autor. A condição c) será mais explorada nas duas seções seguintes, onde apresentaremos as metas do discurso cepalino, e o auditório ao qual ele se dirige. De qualquer forma, fica claro que Prebisch pretende influir sobre a realidade econômica latinoamericana através do impacto de seu discurso sobre as ações dos governos desta região. É por este motivo que Prebisch valoriza a opinião de seu auditório. E é também por este motivo que Hodara (1987: 383) cognomina Prebisch de "profeta armado". 
A última condição, a atenção do auditório, é, a um nível mais formal, assegurada pela própria situação institucional da CEPAL, que confere a este discurso um acesso privilegiado aos governos latino-americanos. A um nível mais substantivo, procuramos demonstrar, no capítulo II, que havia uma predisposição de pelo menos parte da opinião pública latino-americana a acolher o discurso industrialista. Rodriguez chega a afirmar que "o pensamento da CEPAL dos anos cinquenta constitui a forma mais abstrata e ao mesmo tempo analiticamente mais desenvolvida e coerente das ideologias de cunho populista" (Rodriguez 1980: 270).

\section{IV.2- Meta da persuasão}

Como já foi visto no capítulo I, um ponto crucial da análise retórica é a identificação da meta do discurso, ou seja, das proposições que este discurso visa fazer admitir pelo seu auditório. Não necessariamente estas metas são proposições defendidas abertamente, daí a dificuldade de identificá-las. Há que interpretar o discurso para percebêlas.

No caso do Estudio, nossa hipótese é a de que sua meta principal é persuadir o leitor da necessidade de políticas de industrialização e aumento da proteção aduaneira aos produtores industriais na América Latina, enquanto a meta aparente, absolutamente incontroversa, é a necessidade de desenvolvimento da região. Tal interpretação é consistente com a opinião de Di Marco: "The fundamental core of Prebisch's body of thought is concerned with the industrialization process which less developed countries should undergo..." (Di Marco 1972: 3 - ênfase no original). Fundamentamos nossa interpretação com três ordens de argumentos:

a) Argumentos históricos. Procuramos, no capítulo II, mostrar que à época da criação da CEPAL já havia não só opiniões favoráveis à industrialização da América Latina, mas até mesmo políticas econômicas voltadas para este objetivo. O processo de industrialização pelo qual estavam passando vários países da região criava interesses específicos que necessitavam, para se legitimar, de uma justificação teórica. Este aspecto é congruente com uma das condições que Johnson reputa necessárias para a ocorrência de revoluções teóricas: "Novas idéias atingem um auditório público e profissional, não por seus méritos científicos, mas segundo elas prometem ou não uma solução para problemas importantes que a ortodoxia estabelecida provou ser incapaz de resolver" (Johnson 1975: 12).

Por outro lado, economistas como Wageman, Manoilesco e Rosenstein-Rodan já se haviam manifestado também em favor da industrialização. Mais ainda: o próprio Prebisch já se encaminhava, desde a década de 1930, para a crítica da divisão internacional 
do trabalho então prevalecente e do crescimento baseado no setor agrário-exportador. E, finalmente, desde o primeiro projeto de resolução propondo a criação da CEPAL, já estava presente a idéia de fortalecer a posição política e econômica dos países latino-americanos frente aos EUA, o que levava naturalmente à busca de medidas visando reduzir a dependência econômica desta região em relação a seu principal parceiro comercial.

Os reflexos de tal contexto sobre a Comissão são claros. O compromisso com o desenvolvimento é fruto da própria configuração da CEPAL, um órgão intergovernamental formado praticamente só por técnicos e representantes de países latino-americanos e criado justamente com o objetivo de diagnosticar os percalços no caminho do desenvolvimento e propor formas de superá-lo.

A propósito, é significativo o fato de que Kybal, técnico norte-americano pertencente aos quadros da CEPAL, "estava consciente de que não se podia tomar posição contra a industrialização, pois isso seria colidir com posições manifestas de muitos governos latino-americanos" (v. Furtado 1985: 57). E isto no período de formação desta instituição, ou seja, antes da admissão de Prebisch. O que dá bem a medida da ampla adesão reinante no órgão ao objetivo do desenvolvimento, e, mais ainda, ao objetivo mais restrito da industrialização, antes que qualquer argumento fosse aduzido em seu favor.

b) Testemunho de Prebisch. Trinta anos depois da publicação do Estudio, no prefácio ao livro de Octavio Rodríguez, seu autor afirma: "Quando escrevemos nossos primeiros trabalhos, esse conceito [industrialização] estava muito longe de ter sido absorvido com profundidade. Daí o nosso empenho em demonstrar que a industrialização era uma exigência ineludível do desenvolvimento. E, além disso, que, diante da superioridade técnica e econômica dos centros, era necessária uma razoável proteção" (Prebisch 1981: 8 - grifo nosso).

c) Convergência dos argumentos. Fizemos menção, no capítulo I, à interação que ocorre entre os diversos argumentos de um mesmo discurso, e que é uma das características distintivas do discurso retórico. No caso do Estudio, observa-se que a maioria dos argumentos apresentados converge para uma conclusão favorável à industrialização e à proteção alfandegária, em que pese o fato de muitos deles deixarem a conclusão apenas implícita. Tal convergência de argumentos de diversas naturezas é indicativa de que o Estudio, longe de ser um discurso propriamente teórico, especulativo, é voltado para a consecução de um objetivo, e que este objetivo é o descrito acima.

A (pré)existência de uma meta específica permite caracterizar os argumentos apresentados no texto como ad hoc ${ }^{58}$. O que, desde logo, dista muito da aparência do

\footnotetext{
${ }^{58}$ Rodríguez (1981: 174-5) faz uma observação neste sentido, mas não a integra a sua análise da teoria cepalina.
} 
Estudio, a começar pelo nome: estudo sugere um diagnóstico, uma avaliação neutra e descompromissada - supondo que tal seja possível.

Estas considerações nos afastam bastante da abordagem de Rodríguez, que distingue de forma excessivamente rígida o âmbito da teoria econômica e da política econômica cepalinas, inclusive tratando este último em capítulo separado (Rodríguez 1981: cap. 5). Nossa proposição é a de que o primeiro serve aos propósitos do segundo, ao menos na fase inicial da instituição. Por outro lado, para não cairmos no esquematismo oposto, de subordinar de forma absoluta o nível teórico às proposições de política econômica, há que reconhecer que Prebisch tinha também um genuíno interesse sobre o tema do desenvolvimento. Uma outra qualificação é a de que nem todos os efeitos retóricos provocados pelo Estudio são necessariamente intencionais.

É interessante notar que a industrialização conflita potencialmente com ocorrências desejáveis (e como tal reconhecidas pela CEPAL), quais sejam a redução do desemprego e dos desequilíbrios do balanço de pagamentos. No primeiro caso, porque se eleva a intensidade de capital, e no segundo, devido ao aumento das importações de bens de capital e insumos (v. CEPAL 1950: 9; 68-9). Este último problema seria tratado com mais profundidade por Tavares (1964).

\section{IV.3- $\underline{\text { O auditório }}$}

Um dos pontos que caracterizam a análise retórica é a preocupação com a identificação do auditório ao qual se dirige o discurso, já que é a partir das inclinações e crenças deste que o autor parte para aproximá-lo o mais possível das teses propostas. Acreditamos poder identificar este leitor-alvo com o membro de áreas técnicas e/ou políticas de governos latino-americanos, o que é coerente com a história e os objetivos da instituição. Este ponto foi assinalado por Rogge (1959: 8): O Estudio "foi publicado com a finalidade de servir de ajuda direta àqueles que se empenham em traçar diretrizes políticas, tanto no nível nacional como internacional". Um indicador desta característica do discurso cepalino é o fato de ele demandar basicamente ações do Estado: protecionismo, industrialização deliberada ${ }^{59}$ (CEPAL 1950: 69, 77), e outras menos frisadas, como acordos tarifários dentro da América Latina para incrementar o intercâmbio industrial (ibidem: 88).

Da mesma forma, Prebisch nunca se afasta de uma visão "governamental" dos fenômenos econômicos ${ }^{60}$. Os conflitos de classe e os correspondentes interesses econômicos

\footnotetext{
${ }^{59}$ Deliberada se opõe aqui a espontânea, ou seja, a industrialização que deriva da ação de forças de mercado. O qualificativo "deliberada" supõe, portanto, ação do Estado.

${ }^{60} \mathrm{~V}$. Rodriguez (1981: 23).
} 
divergentes brilham pela ausência. Em seu lugar surge o Estado, figurando como intérprete privilegiado dos anseios da sociedade civil, e árbitro de todos os conflitos. É de se notar também a prescrição de fortalecimento do Estado e ampliação de suas funções, implícita no Estudio mas explícita em outros textos cepalinos ${ }^{61}$.

Os escritos de Prebisch nesta primeira fase da CEPAL formam um continuum no que se refere ao auditório visado, que vai de "El desarrollo económico de América Latina y algunos de sus principales problemas", passando pelo Estudio, a "Commercial policies in the underdeveloped countries". Enquanto o primeiro texto é eminentemente programático (tendo sido chamado de o "manifesto de Prebisch") e desdenha o auditório acadêmico ${ }^{62}$, o último é voltado para ele, tendo sido escrito para publicação na American Economic Review. O Estudio tem um propósito híbrido, e portanto opta por uma argumentação híbrida. Furtado (1985: 76) critica esta ambiguidade (sic), que segundo ele teria reduzido seu poder de convencimento tanto nos círculos especializados quanto nos não-especializados.

Voltemos agora a nossa primeira afirmação sobre a natureza do auditório visado por Prebisch: se tanto o emissor quanto o receptor principal do discurso estão ligados aos governos da América Latina, então ambos deveriam ter interesses e pontos-de-vista semelhantes, se não idênticos. Isto não minaria a própria base do discurso, tornando-o supérfluo? Nossa resposta é peremptoriamente negativa, e baseia-se na concepção de governos como organizações complexas, onde concorrem visões e interesses diversos. A própria CEPAL teve dificuldade em se afirmar como instituição representativa dos interesses econômicos do conjunto da América Latina ${ }^{63}$, o que prova que sua posição não era hegemônica.

Para maior clareza, propomos a divisão do auditório-alvo em dois ${ }^{64}$ : um, caracterizado pelo nacionalismo, que já está convencido da necessidade de industrialização. Para este auditório, trata-se de construir um discurso que dê status teórico a suas crenças, e inclusive fundamente suas práticas ${ }^{65}$, já que, como visto no cap. II, a implantação de políticas industrialistas e protecionistas é bastante anterior à teoria cepalina. O outro auditório é que representa o grande desafio para Prebisch: suas crenças liberais e sua confiança na excelência da teoria neoclássica representam um obstáculo considerável à aceitação do discurso industrialista e protecionista. A um tal obstáculo Perelman (1958: 142-3) chama inércia, a

\footnotetext{
${ }^{61}$ Furtado (1985: 85): "os capítulos teóricos [do Estudio\} traziam implícita a mensagem de que os Governos deveriam assumir a orientação do processo de desenvolvimento". V. também Guzmán (1976: 217).

${ }^{62}$ V. Furtado (1985: 61).

${ }^{63}$ V. Santa Cruz (1985: 41-43)

${ }^{64}$ Nossa intenção não é fazer uma taxonomia dos auditórios realmente existentes, mas frisar que há basicamente duas atitudes possíveis frente ao discurso industrialista.

${ }^{65}$ Furtado (1985: 122) interpreta desta forma a recepção calorosa de Vargas às idéias de Prebisch, num encontro pessoal entre os dois últimos, em 1951.
} 
inclinação a manter o status quo até que sejam apresentadas razões convincentes para mudálo.

A escolha de um público-alvo específico, juntamente com a meta da persuasão, orienta e conforma o discurso. Tendo escolhido seu público, Prebisch se vê impedido de contrariá-lo frontalmente. É basicamente por este motivo que a responsabilidade pelo subdesenvolvimento é deslocada do âmbito interno dos países da América Latina para o "centro", ou, mais precisamente, para a iniquidade da divisão internacional do trabalho. É por isto também que as observações sobre a problemática interna desses países são sempre muito abstratas, escamoteando os conflitos de interesse intra-nacionais ${ }^{66}$. Um exemplo eloquente é a ausência, no texto, de qualquer discussão sobre a evidente incompatibilidade, no curto prazo, entre dois objetivos preconizados para a América Latina: o aumento de produtividade, que exigiria a intensificação da acumulação de capital, e a melhoria do nível de vida.

O fato de o auditório ser misto pesou a favor de Prebisch durante a longa discussão sobre a deterioração dos termos de troca: sendo a fração nacionalista do auditório predominantemente leiga, e sendo as críticas à tendência à deterioração eminentemente técnicas, esta fração ficou praticamente imune às críticas.

Sobre a identificação do auditório-alvo, há que se fazer uma qualificação: ele não exclui a existência de um auditório mais amplo, já que o Estado não é absolutamente independente da sociedade civil. Era preciso criar (ou reforçar) a posição industrialista nos segmentos da sociedade civil dotados de poder político.

Finalmente, observamos que o Estudio é adequado ao seu auditório em um sentido particularmente importante. Como um discurso em favor do protecionismo e da industrialização deliberada, ele propõe a seu auditório uma linha de ação concreta, enquanto seu opositor, a teoria neoclássica, propõe basicamente a inação, o laissez-faire, ou apenas uma ação indireta de provimento dos serviços governamentais clássicos ${ }^{67}$. Ora, considerando a função social do auditório cepalino, percebe-se que este estava pressionado de todas as formas a agir. Prebisch provê o conteúdo desta ação, fato que constitui, segundo pensamos, parte importante na explicação da acolhida e influência que teve esta teoria.

Uma explicação subsidiária nos é fornecida por Furtado (1985: 61): "Seu [de Prebisch] poder de convencimento em esferas muito mais amplas era considerável, pois se as 'vantagens comparativas' são uma construção abstrata, os preços do que se exporta e importa são coisas reais". Interpretando esta passagem com auxílio da teoria da argumentação, podese dizer que a teoria das vantagens comparativas poderia aspirar no máximo ao status de verdade, muito menos estável que o status de fato, do qual gozam os preços e suas variações.

\footnotetext{
${ }^{66}$ V. Guzmán (1976: 212). Prebisch abandona esta posição conciliatória a partir de seus estudos sobre o "capitalismo periférico" (v. Pollock 1987: 370).

${ }^{67} \mathrm{E}$ mais algumas ações tópicas e de pouco apelo, como o controle de natalidade.
} 
$\mathrm{Na}$ verdade, esta comparação oblitera todas as mediações teóricas entre o fato da deterioração passada dos termos de troca (o qual é ainda questionável, e questionado) e a verdade da tendência à deterioração.

\section{IV.4 - Principais premissas}

Prebisch tenta infundir no leitor a crença na necessidade da industrialização, tornando-a solidária a crenças às quais, supostamente, o leitor adere ${ }^{68}$.

Dividiremos, segundo o uso de Perelman, as principais premissas do Estudio em valores e lugares - premissas relativas ao preferível - e fatos e verdades - relativas ao real.

Começando pelos valores, temos que o mais importante deles é a desejabilidade do desenvolvimento. Prebisch repete e enfatiza várias vezes esta norma, da mesma forma que deixa na sombra a norma da industrialização e oculta, de fato, a proposição de intervenção estatal na economia. Veja-se, por exemplo, o prefácio do Estudio (CEPAL 1950: ix), onde Prebisch afirma que "se ha presentado atención especial a los problemas que entraña el desarrollo económico de los países latinoamericanos". Outra passagem, ainda mais explícita: "El problema económico esencial de América Latina estriba en incrementar su ingreso real per capita, merced al aumento de la productividad..." (ibidem: 9). De outro ângulo: "La capacidad para importar de América Latina ha aumentado menos que su población, cuando el desarrollo económico de aquella exige un incremento harto mayor" (CEPAL 1950: 47 - grifo nosso). A necessidade de desenvolvimento é tomada aqui como um dado inquestionável. E finalmente: "La agricultura de la América Latina requiere también un progreso técnico considerable, si se ha de elevar el nivel de vida de las masas" (CEPAL 1950: 68 - grifo nosso).

As constantes referências ao desenvolvimento, ao progresso técnico e à elevação do nível de vida ampliam a receptividade do auditório-alvo à pregação cepalina. $\mathrm{Na}$ feliz imagem de Perelman (1958: 223), as referências a valores compartilhados "permitem a comunhão [entre orador e auditório] como o desfraldar de uma bandeira". Observe-se de passagem que o valor desenvolvimento não é o ponto-de-partida primeiro do raciocínio, estando ele próprio fundado num lugar da quantidade. Este último pode ser explicitado da seguinte forma: maior quantidade de bens e serviços, de renda, de bem-estar é preferível a uma menor quantidade. Tal lugar normalmente nos passa desapercebido, por ser um componente fundamental de nosso padrão ideológico e, a fortiori, do padrão do auditórioalvo cepalino.

\footnotetext{
${ }^{68} \mathrm{E}$ à qual, é forçoso reconhecer, a CEPAL também adere. Tal observação nos distancia da concepção popular da retórica como estratagema, como forma de enganar.
} 
O valor justiça também tem um papel importante neste discurso. A metáfora centro-periferia, de que logo falaremos, evoca claramente a idéia de hierarquia, iniquidade e mesmo exploração. É constante, no texto, a comparação entre centro e periferia, ressaltando a assimetria das relações econômicas internacionais instauradas sob o império do princípio da divisão internacional do trabalho.

O capítulo IV do Estudio, como vimos anteriormente, leva o significativo título de "Contrastes e disparidades no processo de desenvolvimento econômico", e intenta fazer uma comparação entre o processo de desenvolvimento dos países "periféricos" do século passado (tomando como paradigma os EUA) e o dos deste século. Enfatiza-se que a diferença tecnológica e de nível de renda entre centro e periferia é hoje muito maior, o que inclusive tende a perpetuar tal diferença: o nível de renda muito baixo tende a ser insuficiente para gerar a poupança e a demanda necessárias para absorver uma tecnologia altamente intensiva em capital e que exige a produção em larga escala. A explicitação de tal "injustiça" torna o leitor mais susceptível a aceitar a intervenção estatal visando corrigí-la.

Igualmente, as seções de 7 a 11 do capítulo II do Estudio tratam dos efeitos do crescimento autônomo da periferia sobre o centro e de como isto repercute novamente sobre a periferia, gerando a tendência ao desequilíbrio do balanço de pagamentos. Tal tendência impediria a periferia de pular o fosso que a separa do centro. Já o estímulo de crescimento que parte do centro para a periferia (e que, afinal de contas, é o que faz do centro, centro) é desconsiderado. Por aí se nota que o que está em relevo não é o fato material do subdesenvolvimento, da pobreza, mas a disparidade, a desigualdade da situação ${ }^{69}$. O que nos leva diretamente a um terceiro valor, o nacionalismo. Arndt (1987: 13-21) argumenta que a motivação básica para as idéias e práticas desenvolvimentistas fora da Europa a partir do século passado, com exceção da Argentina, está numa reação nacionalista à penetração e supremacia européias, e não num desejo abstrato de elevar o nível de consumo da população ou de alcançar o progresso técnico por ele mesmo.

Passemos agora às premissas relativas ao real. A mais saliente e mais frisada delas é um fato (v. cap. I): a deterioração dos termos de troca no comércio entre o centro e a periferia. Esta é uma das premissas do argumento principal do Estudio. A qualidade de fato implica que se pode (como Prebisch fez) postular a seu respeito um acordo universal. O que não quer dizer que este acordo não possa ser rompido, como ocorreu, dando origem à já longa controvérsia dos termos de troca. En passant: o uso dos termos de troca se presta especialmente bem à comparação entre centro e periferia. É provável que um economista mais ortodoxo, na situação de Prebisch, estudasse separadamente o comportamento dos

\footnotetext{
${ }^{69}$ A esse respeito, chama a atenção a seguinte passagem : "...el desarrollo de la industria puede contribuir a nivelar los ingresos de los países de producción primaria con los que obtienen los países industriales" (CEPAL 1950: 59).
} 
preços de importação e exportação, procurando localizar eventuais problemas em mercados específicos.

Sobre a tendência à deterioração, há um dado interessante a acrescentar: conquanto os dados utilizados por Prebisch demonstrem uma piora dos termos de troca durante a Grande Depressão, a comparação entre as médias dos períodos 1925-29 e 1945-49 (dois auges cíclicos) mostra o contrário: "...el promedio [dos termos de troca] del quinquenio 1945-49 aventaja en 4,4 por ciento el del quinquenio de 1925-29" (CEPAL 1950: 18; 19 grifo nosso).

Prebisch ignora este empecilho, o qual só é mencionado nesta passagem específica, e continua afirmando a tendência estrutural à piora dos termos de troca, para a qual ele oferece uma justificativa teórica. Tal tendência na verdade só encontraria algum apoio empírico se, dados dois pontos análogos de dois ciclos, se comprovasse que os termos de troca são sistematicamente maiores no ponto cronologicamente anterior.

Além da deterioração, outros três fatos são postos em relevo na argumentação prebischiana: o desemprego, o desequilíbrio nas contas externas e a disparidade de rendas entre o centro e a periferia. Todos eles são alçados à condição de características estruturais da economia latino-americana, ganhando assim uma forte presença no discurso. Esta presença é ainda reforçada pela repetição constante destes elementos ao longo do texto.

Uma verdade também está entre as principais premissas do Estudio: a validade da teoria neoclássica. O que pode parecer paradoxal, visto que as principais conclusões de Prebisch vão de encontro às prescrições derivadas da teoria neoclássica do comércio internacional, e que o próprio autor enfatiza este confronto.

Só se pode reconciliar esta antinomia, em termos retóricos, lembrando-se que o auditório-alvo da CEPAL é um auditório misto, incluindo também economistas formados na tradição neoclássica ${ }^{70}$. Se o leitor do Estudio adere à teoria neoclássica, é sobre ela que a CEPAL deve-se basear para levá-lo a aceitar suas proposições. O discurso retórico não é, portanto, nem a pura reafirmação do já sabido e aceito, nem sua negação absoluta. Em outras palavras: "...o leitor só se sente satisfeito quando ele pode, no seu pensamento, dar um lugar às noções antigas" (Perelman 1958: 569).

Harry Johnson chega a fazer disto um dos requisitos para o sucesso das teorias. Segundo ele, as teorias vencedoras, em cada época, do debate econômico continham novidades teóricas mas permitiam, também, incorporar as formulações anteriores como casos particulares (Johnson 1971: 4; 8). Assim, no caso em apreço, a teoria neoclássica é acusada não de contradição, mas de ser estática, de não levar em conta a duração da situação de

\footnotetext{
${ }^{70}$ No que se inclui o próprio Prebisch (v. Prebisch 1987).
} 
desequilíbrio no movimento entre duas situações de equilíbrio (CEPAL 1950: 38-9). A teoria cepalina pretende, então, subsumir esta teoria estática, incorporando-a a uma dinâmica.

A própria concepção cepalina do desenvolvimento econômico não difere essencialmente da neoclássica: é este um processo de acumulação de capital concomitante ao progresso tecnológico ${ }^{71}$. Algumas vezes o desenvolvimento é mesmo igualado a elevação da densidade de capital (CEPAL 1950: 73) ${ }^{72}$.

Em outros pontos Prebisch também recorre a raciocínios tipicamente neoclássicos, como a igualação das produtividades marginais, para a determinação da intensidade de capital ótima (ibidem: 70-71). Mesmo a sua tese principal, sobre a necessidade da industrialização, é justificada pelo fato de que, devido à deterioração dos termos de troca que o modelo de crescimento para fora acarreta, a maximização da renda só é alcançada com um certo grau de industrialização deliberada, isto é, controlada pelo Estado. Este ponto se torna mais explícito no modelo de Rodriguez (1981: cap. 4), que formaliza o argumento cepalino central. O uso do raciocínio e até da nomenclatura neoclássica aumenta a comunhão com uma parcela do auditório.

A par das premissas de ordem geral estão as que fazem parte de argumentos específicos, muito numerosas para ser descritas. Julgamos de utilidade, no entanto, dar um exemplo deste tipo de análise. No argumento principal do Estudio, Prebisch comenta que, como o aumento de produtividade na indústria é mais rápido que na agricultura, a teoria exigiria que os preços industriais também caíssem mais rápido que os agrícolas - implicando melhoria dos termos de troca para a periferia. "Los productores primarios se encontrarían de tal suerte en igualdad de condiciones que los industriales para compartir con ellos el fruto del progreso técnico." (CEPAL 1950: 49-51). A frase aparentemente é apenas descritiva, mas a referência à "igualdade de condições", valor presente no auditório, faz com que este se incline a aceitar a situação de melhoria contínua dos termos de troca como a situação justa, logo, desejável. Isto apesar de, poucas páginas depois (ibidem: 57), Prebisch descartar quaisquer considerações éticas. Mas o que nos interessa destacar aqui são duas outras premissas, ambas implícitas. A primeira: a igualdade na distribuição dos frutos do progresso técnico supõe uma comparação entre o esforço de aumentar a produtividade e sua recompensa (crescimento da renda real). Eles devem manter uma relação de proporcionalidade. A segunda: o autor, na frase citada acima, fala no fruto do progresso técnico, quando ele próprio diz que este é mais intenso (e, portanto, o esforço de produzí-lo) no centro que na periferia. Só esquecendo-se este fato é possível falar em compartilhar o

\footnotetext{
${ }^{71}$ Sobre a relação de continuidade entre a teoria neoclássica e a cepalina v. Guzmán (1976: 216-7).

${ }^{72}$ V. Rodriguez (1981: 36-7).
} 
fruto do progresso técnico, e só assim se pode tornar o caso de melhoria dos termos de troca eticamente justificável ${ }^{73}$.

O ponto que acabamos de descrever, embora simples, demonstra a necessidade de se atentar para as premissas, o mais das vezes implícitas - e por isto mesmo mais eficientes - necessários à dedução das conclusões.

${ }^{73}$ É por este motivo que Flanders (1964a: 311) afirma que Prebisch considera o progresso técnico uma atividade sem custos. Sem custos, torna-se indiferente o fato de o progresso ser maior no centro. 


\section{IV.5- a escolha dos dados}

Pelo dito até aqui, percebe-se que a ênfase recai sempre sobre as relações internacionais e sobre os problemas oriundos do setor exportador das economias latinoamericanas, colocando em plano secundário outros fenômenos correntemente aceitos como geradores de subdesenvolvimento, tais como: os supostos defeitos intrínsecos do caráter latino-americano, escassez de capital, tecnologia agrícola primitiva, falta de transportes, educação deficiente, escassez de capacidade empresarial etc ${ }^{74}$. É significativo que todos os dados numéricos apresentados, com exceção do crescimento populacional e da porcentagem de população ativa empregada na produção primária, sejam referentes ao comércio exterior. São, ao todo, onze tabelas e cinco gráficos. Os cepalinos ${ }^{75}$ tendem a acentuar que sua teoria veio preencher uma brecha entre a realidade econômica dos países latino-americanos, que estavam-se industrializando, e o papel que, conforme alegam, lhes era imputado pela teoria neoclássica do comércio internacional. Esta propunha a especialização dos diversos países na produção dos bens que lhes garantissem vantagens comparativas. Os estudos da CEPAL, ao apresentarem uma série de justificativas para a industrialização, pareciam estar mais de acordo com o mundo real, cujos acontecimentos eles permitiam racionalizar.

Por outro lado, o boom das exportações primárias latino-americanas no pósguerra era, ao lado da industrialização, um dado econômico marcante, e que favorecia o argumento próespecialização na produção primária. No entanto, este dado foi sistematicamente desprezado ou minimizado na produção teórica cepalina da época ${ }^{76}$. Longe dos olhos, longe do coração. Assim também o sucesso econômico de países exportadores de produtos primários, como Austrália, Nova Zelândia e Dinamarca não é sequer mencionado no Estudio.

As características diferenciadas dos países da América Latina (em tamanho, especialização, nível de renda, tipo de colonização, recursos naturais etc.) são mencionadas uma única vez (CEPAL 1950: 5-7), mas não afetam a argumentação: a prescrição de industrialização é generalizada ${ }^{77}$. Mesmo o caso dos países exportadores relativamente bem sucedidos (Venezuela e Cuba) só aparece em duas passagens (CEPAL 1950: 9; 84-87) e não altera a prescrição industrialista: Prebisch prefere enfatizar que nestes países a proteção alfandegária das atividades produtoras de bens para consumo interno é ainda mais necessária

\footnotetext{
${ }^{74}$ A este respeito, v. DiMarco (1972: 31).

${ }^{75}$ V. Furtado (1985), CEPAL (1950), CEPAL (1969: 14-16).

${ }^{76}$ Aparece, no entanto, no Estudio de 1948 (CEPAL 1949: 235), anterior à ascensão de Prebisch à secretaria-geral da CEPAL.

${ }^{77}$ Aníbal Pinto diz mesmo que as colocações cepalinas são generalizações da experiência do Cone Sul, formado por países relativamente homogêneos (apud Guzmán 1976: 347).
} 
- porque é maior a disparidade de produtividade entre os setores produtores de bens para consumo interno e externo.

Ainda outro fato minimizado: o crescimento da população. Em momento algum Prebisch propõe a redução deste crescimento, apesar de diagnosticar um excesso estrutural de oferta de mão-de-obra no setor primário. Uma passagem particularmente interessante, neste sentido, é a que trata da redução, entre 1925 e 1949, da capacidade para importar per capita ${ }^{78}$. Prebisch mostra que este indicador cai $15,6 \%$ no período, e atribui esta queda à redução do quantum de exportações e à deterioração dos termos de troca. $\mathrm{O}$ primeiro realmente cai $16,6 \%$, mas os termos de troca sobem $4,4 \%$, e a população cresce 44,35\%. Ou seja, a redução da capacidade para importar per capita deveria ser atribuída prioritariamente ao crescimento da população.

Na seção 3 do capítulo I ocorre um uso curioso dos dados empíricos. Nela Prebisch apresenta dados de taxa de crescimento populacional (da qual diz que é alta), porcentagem da população ativa empregada na produção primária (idem) e exportações per capita. Estas últimas estão, de acordo com o quadro 1 (CEPAL 1950: 8), crescendo, mas Prebisch pondera que as exportações per capita em dólares constantes devem estar caindo - o que, diga-se de passagem, é duvidoso. A conclusão obtida a partir destes dados é a de que "las exportaciones son también insuficientes para hacer frente a las exigencias del desarrollo económico" (CEPAL 1950: 9). Ora, esta conclusão não segue das premissas acima expostas, por mais boa vontade que tenha o leitor. E, no entanto, este ponto não foi criticado em toda a literatura sobre a CEPAL analisada para esta dissertação. É possível que a massa de dados apresentada, bem como o estilo entimemático de Prebisch, tenham contribuído para desviar a atenção dos leitores desta falha.

\section{IV.6- Apresentação dos dados: presença}

Na seção anterior tratamos da escolha dos fatos, pela qual alguns deles ganham presença no discurso, enquanto outros, conquanto em princípio relevantes para a discussão do tema desenvolvimento, são deixados na sombra. Mas pode-se também realçar ou reduzir a presença através da forma de apresentação do discurso.

A necessidade de fazê-lo está presente em todo discurso não totalmente formalizado. É preciso destacar para o auditório o objeto do discurso, os fatos essenciais, os

${ }^{78}$ Assim definida: $c a p a c=\frac{X \cdot P_{x}}{N \cdot P_{m}}$. Ou, de outra forma: $\frac{X}{N} \cdot \frac{P_{x}}{P_{m}}$. Onde X representa o volume físico das exportações da América Latina, $\mathrm{N}$ sua população, $\mathrm{P}_{\mathrm{X}} / \mathrm{P}_{\mathrm{M}}$ os termos de troca. A passagem acima referida está em CEPAL (1950: 18-19). 
argumentos centrais, mantendo-os presentes em sua consciência. Numerosos procedimentos e figuras visam este fim, como, por exemplo, a repetição.

Comecemos pela repetição de argumentos. A afirmação de que as exportações são insuficientes para fazer frente às exigências do desenvolvimento é repetida três vezes (CEPAL 1950: 9; 12; 73). O mesmo se dá em relação à proposição de que o crescimento das exportações é insuficiente para absorver o crescimento da população (ibidem: 6; 9; 12).

Outros exemplos de repetição referem-se a três afirmações: a) a de que a lentidão da propagação do progresso técnico é responsável pelas disparidades de renda e produtividade é repetida três vezes ao longo do texto (ibidem: $3 ; 48 ; 78$ ); b) a de que o aumento de produtividade nas atividades primárias gera ou amplia o excedente populacional, o que justifica a industrialização, mencionada quatro vezes (ibidem: 56; 58; 68; 82); c) a de que a proteção alfandegária na periferia é uma resposta à queda do coeficiente de importação do centro, três vezes (ibidem: 41; 42; 44). E, finalmente, todos os capítulos a partir do segundo começam retomando alguma afirmação feita anteriormente.

São inúmeras as referências à queda dos termos de troca ou a sua variante, a má distribuição dos frutos do progresso técnico. A frequência com que são utilizadas as expressões centro e periferia, industrialização, excedente populacional não deixa dúvidas quanto à direção da argumentação de Prebisch. Cada aparição destas expressões reforça a familiaridade do leitor com as mesmas, aumentando sua adesão às teses propostas.

Os próprios dados numéricos são repetidos. A queda da capacidade para importar é ilustrada com os preços no comércio América Latina-resto do mundo, América Latina-EUA e América Latina-Inglaterra (ibidem: 17; 21; 25). A queda do coeficiente de importação do centro é exemplificada com o caso dos EUA e da Inglaterra (ibidem: 22; 26). E a queda da capacidade da América Latina para importar per capita traduz essencialmente a mesma informação que a queda das exportações per capita ${ }^{79}$.

Um outro efeito de presença é obtido com a exposição de uma proposição e, logo em seguida, de uma simulação numérica que exemplifica esta proposição, tornando-a mais concreta e mais inteligível (logo, mais aceitável) para o leitor. Tal procedimento é adotado em seis pontos diversos do texto (ibidem: 37; 40; 49; 52; 71; 87).

\section{IV.7- Apresentação dos dados: Outros aspectos}

\footnotetext{
${ }^{79}$ CEPAL (1950: 18-19). A primeira cai, no período 1925-1949, 15,6\% e a segunda 19,1\%. O fator mais importante para explicar a queda é o mesmo em ambas, qual seja, o aumento populacional (v. pg. 61 atrás).
} 
Além de conferir presença aos elementos do discurso, a forma de sua apresentação influi sobre uma série de aspectos relevantes para a determinação de seu poder de convencimento. Assim, por exemplo: revela o engajamento do autor em relação a uma causa, ou, ao contrário, sua neutralidade; aproxima-o ou o afasta do auditório (por meio de um discurso muito técnico, pedante ou hostil); coloca sob uma luz favorável ou desfavorável o mesmo fato.

Um dos pontos notáveis do Estudio é o uso de uma linguagem de convicção (v. Koch 1974), pela qual as afirmações são transmitidas não como sentimentos pessoais do orador, hipóteses ou suposições, mas como fatos inquestionáveis ou conclusões de raciocínios válidos, apoiados em premissas igualmente inquestionáveis. Tal linguagem é reforçada pelo uso de expressões tais como: "é claro que", "é óbvio que", "evidentemente" e correlatas (CEPAL 1950: 3; 16; 37; 52; 61; 80). Coerentemente, não há orações na primeira pessoa, nem do singular nem do plural, as quais revelariam inevitavelmente o orador como orador, como portador e transmissor de crenças e opiniões. O tom professoral (didático, sem torneios linguísticos e firme) contrasta com o tom de manifesto do texto de 1949 "El desarrollo económico de América Latina y algunos de sus principales problemas" (Prebisch 1962) ${ }^{80}$.

Outro componente da apresentação do discurso é a escolha dos termos. A este respeito, nos ateremos a um só exemplo, presente no argumento principal do Estudio, que é o tratamento dispensado à apropriação dos frutos do progresso técnico. Quando Prebisch se refere à situação em que a redução de preços causada pelo aumento de produtividade no setor exportador da periferia é mais que proporcional a este aumento, tal fato é qualificado de transferência dos frutos do progresso técnico da periferia para o centro (p. ex. CEPAL 1950: 57). Quando o centro é que sofre tal redução de preços, o centro está repartindo seu progresso técnico com a periferia (CEPAL 1950: 49). A duplicidade do tratamento viola a regra de justiça, mas a sutileza do procedimento permite que isto passe desapercebido pela maioria dos leitores, e ao mesmo tempo dá-se a impressão de que a transferência dos frutos do progresso técnico num sentido é iníqua, expoliativa, ao passo que no sentido inverso é justa e natural.

É absolutamente diferente a percepção deste problema pela teoria neoclássica. A distribuição dos frutos do progresso técnico é relegada a segundo plano, e em seu lugar trata-se da variação do bem-estar devido ao aumento de produtividade (v., p. ex., Viner 1951 e Haberler 1964). Assim, uma mesma situação poderia ser descrita, na ótica cepalina, como transferência do progresso técnico da periferia para o centro e, na ótica neoclássica, como um aumento do bem-estar na periferia.

${ }^{80}$ Cf. Furtado (1985: 76). Sobre o estilo "catedrático", v. Hodara (1987b: 56-7). 
O estatuto das premissas também é utilizado pelo orador para aumentar a eficácia de seu discurso. No caso em tela quer-se promover o valor industrialização, tornando-o solidário a outros valores, a saber, a desejabilidade do desenvolvimento, especialmente em termos relativos, e do fim da condição de dependência (v. seção IV.4 acima). E, realmente, só se pode deduzir rigorosamente um juízo de valor se entre as premissas houver juízos de valor ${ }^{81}$.

No entanto, Prebisch procura dar a seus argumentos um fundamento mais firme que o de julgamentos de valor, apresentando seu texto como uma descrição de fatos ${ }^{82}$, e as conclusões a que chega como decorrência lógica destes fatos, tornando-as incontestáveis, ao menos para o leitor imparcial. No caso específico da CEPAL, acresce que suas prescrições já eram explícitas demais, dada sua posição institucional, e era preciso tirá-las do primeiro plano. Finalmente, observe-se também que uma tal estratégia corresponde aos ideais positivistas, que separam radicalmente a economia positiva (a "verdadeira" ciência econômica) da normativa ${ }^{83}$.

Assim, a tentativa de parecer neutro em relação a interesses particulares leva a afirmações do tipo: "...se comienza a sentir imperiosamente la necessidad de suplir la deficiencia de aquel factor dinámico tradicional [as exportações primárias]..." (CEPAL 1950: 55 - grifo nosso). O meramente desejável se torna, assim, "imperiosamente necessário". E quem há de contestar um julgamento de fato, de mais a mais expresso de forma tão veemente?

Em outro trecho a noção de "função" também permite transformar o desejo em necessidade: "A la industria y a las actividades que dependen directa o indirectamente del desarrollo de aquella les corresponde, de hecho, la función de absorber tal sobrante [de mãode-obra no setor primário]" (CEPAL 1950: 50).

Outro artifício de apresentação consiste em anunciar uma conclusão como se fosse uma premissa, e, mais que isto, um fato: "Esta relación [de causalidade] entre el coeficiente de importación de los países industriales y los términos del intercambio entraña la mera expresión de un hecho..." (CEPAL 1950: 48 - grifo nosso). Aqui, a conclusão de uma argumentação que ocupa quase todo o capítulo II do Estudio é apresentada explicitamente como fato. O que poderia ser considerado fato é a queda do coeficiente de importação do centro e a deterioração dos termos de troca, não a relação de causalidade entre elas.

\footnotetext{
${ }^{81}$ Como o atestam R. M. Hare e A. N. Prior, apud Toulmin (1958: 161-2).

${ }^{82}$ E é notável a citação contínua de dados, cifras e acontecimentos históricos, bem como o tom descritivo com que Prebisch inicia o Estudio, o qual contrasta muito com o "manifesto de Prebisch" (Prebisch 1962), que o antecedeu de pouco.

${ }^{83}$ Para Perelman (1958: 680-1), a distinção entre julgamentos de fato e de valor não pode ser feita em abstrato, mas somente dentro de práticas argumentativas particulares - vale dizer, no interior de um mesmo auditório.
} 
Há ainda outros indicadores desta busca da aparência de neutralidade. Um deles é o título, com o termo Estudio sugerindo o distanciamento teórico e o nãoengajamento que supostamente devem caracterizar um texto científico, de mais a mais produzido por um órgão das Nações Unidas, onde, portanto, os interesses de todos os países deveriam ser igualmente contemplados. A mesma neutralidade do nome Estudio se repete na forma como Prebisch se refere a ele no próprio texto: "informe" (p. ex., CEPAL 1950: 35; 89).

A par destes procedimentos retóricos, Prebisch proclama sua neutralidade: "No corresponde a la índole de este informe discutir asuntos de política econômica ni señalar las ventajas e inconvenientes de soluciones alternativas" (CEPAL 1950: 12). E, em outra passagem: "La mención de estos hechos [medidas protecionistas tomadas pelos países centrais] se hace con propósito de estricta objectividad. No se trata de juzgar la política que estas medidas presuponen..." (CEPAL 1950: 81) ${ }^{84}$. O que lhe permite também descartar as considerações morais que lhe são desfavoráveis: "Que los centros tiendan a quedarse con el fruto de su propio progreso técnico no significa que se adueñen de algo que no les corresponda. Desde el punto de vista ético, seria posible encontrar más de una justificación a esta realidad. Pero no es este asunto que nos concierna en el presente informe..." (CEPAL 1950: 57).

Ao mesmo tempo, Prebisch procura apresentar a posição neoclássica como radicalmente contrária à industrialização da periferia: "...la idea de seguir atribuyendo a los países periféricos el papel exclusivo de productores primários..." (CEPAL 1950: 14). Ora, a teoria das vantagens comparativas, em qualquer de suas versões, é abstrata demais para admitir como conclusão a atribuição de um setor produtivo específico a países específicos. Viner (1951: 82) reclama desta deturpação da teoria neoclássica.

Outra deturpação, esta provavelmente involuntária: o autor atribui à teoria neoclássica do comércio internacional a premissa de absoluta mobilidade internacional dos fatores de produção 1950: 14; 57-8) e a critica, por irrealista. Ocorre que esta premissa não faz parte do modelo de Heckscher-Ohlin, expressão da moderna teoria do comércio internacional, que prova as vantagens da especialização supondo dadas as dotações internacionais de fatores, ou seja, precisamente o oposto do que nosso autor lhe atribui (v. por exemplo, Ellsworth 1978: 95-99; também Guzmán 1976: 344).

Um último aspecto relativo à apresentação do discurso diz respeito ao uso da modalidade interrogativa (v. Perelman 1958: 214-5). Quando Prebisch pergunta "quales son las fuerzas que permiten a los centros industriales presionar en esta forma a la periferia y

\footnotetext{
${ }^{84}$ Compare-se estes trechos com as palavras que Beautell (1987: 350) põe na boca de Prebisch: "Yo no he sido, ni soy, ni seré neutral. Yo estoy hondamente comprometido con el desarrollo...". Ao que se deve acrescentar que nosso autor estava também profundamente comprometido com as políticas econômicas que julgava necessárias para promover o desenvolvimento.
} 
retener así el fruto del propio progreso técnico o aun adueñarse de una parte del fruto periférico?" (CEPAL 1950: 61), ele supõe (e sugere) que o leitor já tome como dada a existência desta "pressão" do centro sobre a periferia e a transferência dos frutos do progresso técnico.

Uma outra questão presente no Estudio é tão enfática, conduz tanto o leitor, que constitui uma boa ilustração do conceito de questão retórica: "...que mueve a preguntarse si el incremento de productividad no sería mayor, cuando el capital se distribuyese racionalmente entre los sectores donde la productividad pudiera aumentarse considerablemente, antes que exagerar la densidad de capital en ciertas actividades..." (CEPAL 1950: 73). As palavras "racionalmente" e "exagerar" já indicam (mais do que isto, impõem) ao leitor uma resposta determinada. A questão retórica é questão somente na forma, constituindo, na essência, uma afirmação. Sua vantagem sobre esta está em engajar o leitor, dando-lhe a ilusão de responder ele mesmo à pergunta.

Uma vez conhecidas as premissas do discurso cepalino e os aspectos mais relevantes da forma de sua apresentação, passaremos às técnicas argumentativas propriamente ditas.

\section{IV.8- Argumentos que fundam a estrutura do real: metáforas}

"Fueron formando-se asi [através da propagação limitada do progresso técnico] los grandes centros industriales del mundo, en torno a los quales, la periferia del nuevo sistema, vasta y heterogénea, tomaba escasa parte en el mejoramiento de la productividad" (CEPAL 1950: 3 - grifo nosso). É assim, logo na primeira página do Estudio, que Prebisch introduz o leitor a sua metáfora mais importante.

A existência do sistema centro-periferia não é postulada como objeto teórico (o que exigiria qualificações e explicações) mas simplesmente afirmada como característica essencial ("estrutural") da realidade econômica. Menos ainda Prebisch deixa transparecer seu caráter metafórico. Este caráter, que salta aos olhos numa leitura retórica do texto, implica, como vimos na seção I.2, numa aproximação essencialmente arbitrária entre dois domínios do real, no caso, entre o econômico e o geométrico-espacial.

Fazendo isto no começo do Estudio, Prebisch "funda a estrutura do real", introduzindo o leitor de chofre no mundo por ele criado, minimizando uma eventual resistência intelectual. Posteriormente, o autor apresentará as inúmeras implicações da noção seminal, numa argumentação que só fará reforçar esta mesma noção. 
O raciocínio analógico subjacente pode ser entendido da seguinte forma: os países subdesenvolvidos estão para os países desenvolvidos (domínio do thème, econômico) assim como a periferia está para o centro (domínio do phore, espacial-geométrico). A analogia se torna metáfora quando os termos do thème são suprimidos e substituídos pelos do phore.

Conquanto não pretendamos nos estender neste campo, é preciso observar que o phore centro-periferia tem uma longa história em nossa civilização, tendo sido utilizado em diversas metáforas, e carregado de valores em cada um de seus avatares. Um dos episódios mais antigos desta história foi escrito por Plotino, filósofo latino do século III DC cuja metafísica incluía como elemento importante a idéia de círculo, onde a circunferência retiraria suas propriedades do centro (v. Perelman 1958: 514). Outras manifestações deste phore estão: na disputa entre heliocentrismo e geocentrismo, a qual também confere importância ao centro por contraposição aos elementos periféricos; na metáfora dos centros nervosos; na dos centros urbanos etc.

Os conceitos de centro e periferia no campo econômico, segundo Love (1980: 63), têm origem em Werner Sombart. Já segundo Hodara (1987: 389), foram criados pelo economista teuto-chileno Ernst Wageman. Substituindo a dicotomia países desenvolvidos/ subdesenvolvidos, ou a prática mais tradicional de distinguir os países atrasados, ambas se limitando a registrar a disparidade de graus de desenvolvimento, a nova metáfora desloca a atenção do leitor para as causas desta disparidade, elegendo uma em particular, a saber, as relações econômicas internacionais assimétricas e, por isto, iníquas. A nova dicotomia acentua a relação de dependência dos países pouco ou não-industrializados em relação aos industrializados, constituindo-se, só por isto, e sem que o leitor tenha uma noção muito clara do artifício, num argumento em favor da industrialização, antes mesmo que argumentos de ordem empírica ou teórica tenham sido aduzidos.

Os conceitos de centro e periferia constituem não só uma metáfora como também um argumento baseado na estrutura do real, mais especificamente um argumento de dupla hierarquia. De fato, pelo que vimos de dizer, os elementos do phore não estão no mesmo nível, sendo o centro valorizado em relação à periferia. Tal hierarquia se transfere do domínio do phore para o do thème, enriquecendo a metáfora. Esquematicamente:

\begin{tabular}{|c|c|c|}
\hline $\begin{array}{c}\text { domínios do real } \\
\text { hierarquia }\end{array}$ & phore & thème \\
\hline \multirow{2}{*}{$\begin{array}{c}\text { superior } \\
\text { inferior }\end{array}$} & centro geométrico-espacial & centro cíclico \\
\cline { 2 - 3 } & periferia geométrico-espacial & periferia \\
\hline
\end{tabular}


A estrutura do real criada pelos conceitos de centro e periferia é diferente da instituída pela Microeconomia, baseada na racionalidade dos agentes econômicos individuais. Bem ao contrário do individualismo metodológico que caracteriza a Microeconomia, no Estudio os agentes, suas necessidades, suas ações, são coletivas. Citamos algumas passagens particularmente claras a este respeito: "Es bien sabido que [...] a medida que la técnica moderna aumenta la productividad, va creándose un sobrante de potencial humano que la agricultura ya no requiere. Se apela entonces a la industria y otras actividades, para absorver productivamente esa fuerza de trabajo" (CEPAL 1950: 4 - grifo nosso). Um raciocínio tão abertamente teleológico exige a personificação da periferia, tornando-se, ela própria, agente. Também: "...el progreso técnico [...] generalmente no penetra sino allí en donde se hace necesario para producir alimentos y materias primas a bajo costo..." (CEPAL 1950: 3 - grifo nosso). E ainda: "Si bien una gran parte de los países de la periferia y entre ellos los de la América Latina, parecen haber tomado ya la determinación de radicar en su propia economia el desarrollo de la industria..." (CEPAL 1950: 14).

Uma característica importante da estrutura do real assim criada é a de minimizar ou mesmo desconhecer o conflito de interesses econômicos no interior da periferia, seja entre países, seja entre agentes econômicos de um mesmo país. A história econômica da América Latina e as diferenças entre os países da região também permanecem na sombra, para melhor ressaltar as características "estruturais" que são o foco da preocupação cepalina ${ }^{85}$.

Outras metáforas, embora menos fundamentais para a teorização cepalina, e não exclusivas dela, são as de desenvolvimento "orgânico", "equilíbrio", "frutos" do progresso técnico e "nivelação" das rendas. Exemplos destas metáforas podem ser encontrados, respectivamente, às páginas 3, 9, 49 e 59 do Estudio. Na verdade, devido a seu caráter convencional (tais metáforas nem sequer chamam a atenção do leitor) podemos, com Bicchieri (1988: 106), considerá-las catacreses, ou seja, meros substitutos idiomáticos usados à falta de expressões mais literais. Registre-se também uma ausência relevante: no texto que inaugura a teoria estruturalista do desenvolvimento, não há nenhuma referência a "estrutura" ou seus cognatos. A expressão "estrutura econômica" só aparece na "Carta de Transmisión" que precede o Estudio, e mesmo assim como catacrese.

\section{IV.9- Técnicas de identidade completa: identificação entre conceitos}

\footnotetext{
${ }^{85}$ Segundo Furtado (1985: 67), "A visão de Prebisch era essencialmente sincrônica".
} 
Esta seção e as duas seguintes tratarão dos argumentos quase-lógicos, que tomam como modelo argumentos formalizados tradicionais, sem poder, no entanto, dada sua natureza retórica, ser classificados entre eles.

Ao contrário da identificação total e explícita entre conceitos, presente numa definição, a principal identificação do Estudio não é ressaltada. Nem por isto é menos importante para o projeto de persuasão cepalino.

Já nos dois primeiros parágrafos do Estudio identifica-se progresso técnico com industrialização. O primeiro deles afirma que a propagação do progresso técnico no mundo tem sido lenta e irregular. O segundo conclui que por este motivo foram-se formando os grandes centros industriais do mundo, e, por exclusão, a periferia do sistema. Se não há outro tipo de desenvolvimento que não o industrial, a industrialização está justificada, assim como todas as medidas necessárias a sua implantação. Esta identificação ocorre ao longo de todo o Estudio, particularmente nas páginas 39 ("países en vía de desarrollo industrial"), 48 ("el desarrollo industrial en el mundo"), 51 ("tanto la industria como las actividades que le están vinculadas han crescido en forma relativamente lenta..."; e, dois parágrafos adiante: "la relativa lentitud con que el progreso técnico se ha ido propagando"), 55 ("factor dinámico surgido del própio desarrollo industrial") e 65 ("quando se desarrollaron industrialmente los países..."). É notável a insistência deste procedimento, ao mesmo tempo que sua sutileza.

\section{IV.10- Técnicas de identidade parcial: $\underline{\text { Regra de justiça }}$}

Prebisch faz uso daquilo que Perelman chama de regra de justiça, que "exige a aplicação de um tratamento idêntico a seres ou situações que se julga integrar uma mesma categoria" (Perelman 1958: 294).

Um destes casos vem socorrer diretamente o protecionismo na América Latina. As seções de 1 a 5 do capítulo $\mathrm{V}$ do Estudio se empenham em mostrar o protecionismo dos países centrais: Estados Unidos e Inglaterra (CEPAL 1950: 78; 80; 82). Procura-se assim justificar a proteção aduaneira à indústria na periferia, de forma a "impedir que los grandes países industriales, en virtud de su mayor productividad y apesar de sus altos ingresos perjudiquen el desarrollo de la industria en los primeros [os países de baixa renda] e disminuyan así los ingresos de estos..." (CEPAL 1950: 83-4).

Note-se que aqui, ao invés de ressaltar as diferenças entre centro e periferia, o argumento se serve de uma característica comum aos dois, a saber a de serem ambos um conjunto de países. Nessa condição, ambos teriam igual direito à defesa de suas conveniências econômicas. Servindo-nos da diferenciação interna do auditório postulada na 
seção IV.3, é preciso dizer que este argumento apela à sua porção nacionalista. Ou, de maneira mais geral, à faceta nacionalista de todo leitor latino-americano.

Também visando a defesa do protecionismo na América Latina, está a referência ao baixo coeficiente de importação dos EUA. Com a transferência do núcleo do centro da Inglaterra para os EUA depois da I Guerra, e a consequente redução do coeficiente de importação do centro como um todo, os países periféricos se viram obrigados "a tomar medidas que en una forma u outra, tienden a rebajar el coeficiente de importación", forma eufemística de referir-se ao protecionismo (CEPAL 1950: 41). 


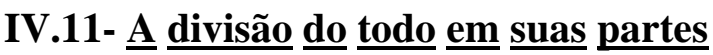

Ainda entre os argumentos quase-lógicos figuram os argumentos de divisão, que permitem tanto demonstrar a existência do conjunto das partes (através da enumeração de cada uma delas) quanto provar a existência ou não-existência de uma delas. O argumento de que vamos tratar encaixa-se no segundo caso, e toma como modelo lógico o princípio do terceiro excluído, do qual só difere porque a exaustividade do conjunto é suposta, e não evidente. O procedimento consiste em propor pelo menos duas hipóteses, ou possibilidades, ou soluções para um problema, e criticar (idealmente, demonstrar a impossibilidade de) todas elas menos uma. Supondo que o conjunto das hipóteses seja exaustivo, a hipótese remanescente aparece como uma escolha natural, inevitável, que independe da vontade do autor, e mesmo dos agentes econômicos ${ }^{86}$.

No caso da CEPAL, a escolha proposta é entre o desenvolvimento centrado no setor primário-exportador e o centrado no setor secundário, voltado para o mercado interno. A maior parte do texto é gasta na tentativa de associar a primeira hipótese ao surgimento de desproporções entre os setores produtivos (desajustes estruturais) e de desequilíbrios derivados destas desproporções (desemprego, deterioração dos termos de troca, déficits crônicos do balanço de pagamentos). Assim, a industrialização deliberada se justifica como meio inelutável de evitar estas mazelas ${ }^{87}$.

Em algumas passagens Prebisch insiste sobre o caráter necessário, compulsório de suas conclusões: "...la pérdida de reservas [com o desenvolvimento da América Latina e consequentes déficits no balanço de pagamentos] llegaría a ser tan grande, que o tendrá que atenuarse o detenerse el desarrollo económico, o si este há de persistir, deberá rebajarse progresivamente el coeficiente de importación." (CEPAL 1950: 38); "...los países de esta [da periferia] no tienen otra forma de absorber el sobrante de su polación activa que desarrollar su propia actividad industrial..." (CEPAL 1950: 50 - grifo nosso); "Es fácil imaginar las consecuencias de este hecho [progresso técnico na agricultura latino-americana], en las hipótesis que examinamos, si la industria y demás actividades no absorbieran, como en los países céntricos, la población ya sin empleo en la tierra: la desocupación provocada por el progreso técnico no permitiria el alza de salários y hasta los disminuiría, y el fruto de dicho progreso se perderia..." (CEPAL 1950: 68); "...no existiendo otra forma de absorber población activa ni de mejorar su productividad, las actividades desarrolladas gracias a la

\footnotetext{
${ }^{86}$ Registramos, en passant, a notável congruência deste raciocínio com o determinismo situacional, característica que Latsis (1976) coloca no centro do programa de pesquisa neoclássico.

${ }^{87}$ Rodriguez (1981: 45; 250-2) chama este tipo de argumento de "raciocínio a contrario sensu", o qual ele acredita ser o eixo em torno do qual se organiza toda a teoria cepalina, e o qual enfatiza as peculiaridades estruturais das economias periféricas.
} 
protección son las únicas asequibles para lograr, dentro de ciertos límites, un incremento del ingreso total" (CEPAL 1950: 89 - grifo nosso).

Estas passagens marcam a transposição de um julgamento de valor (a desejabilidade da industrialização) em um julgamento de fato (a necessidade da industrialização), aumentando a impressão de neutralidade ${ }^{88}$. Tal impressão é ainda reforçada quando a conclusão do argumento de divisão não é explícita, como nos trechos citados, mas é deixada ao leitor. E é isto que ocorre na maior parte do Estudio. Esses entimemas favorecem o engajamento do leitor à causa cepalina, porque este toma as conclusões que tira como se fossem criação sua.

Se as demais alternativas estão descartadas, o autor não precisa apresentar argumentos positivos em favor da industrialização. Esquiva-se, desta forma, a possíveis críticas, e, mais importante, sem revelar sua posição industrialista a priori, que compõe o âmbito normativo da teoria cepalina. A defesa direta da industrialização é, por outro lado, a estratégia adotada por Singer (1961: 173), que usa como argumento os efeitos da industrialização sobre o nível geral de educação, habilidades, nível de vida etc. Neste caso, o valor industrialização é passível de contraposição a outros valores, como a maior eficiência da alocação de recursos a nível mundial permitida pela divisão internacional do trabalho.

Há que dizer ainda que, no caso da CEPAL, algumas possibilidades são arbitrariamente eliminadas, o que causa estranheza a Flanders: "Além disto, não é óbvio o motivo pelo qual o excesso de mão-de-obra não poderia ser utilizado com sucesso na produção de bens que são provavelmente bens domésticos independentemente dos termos de troca [...] devido aos custos de transporte: construção de vários tipos, incluindo a de capital social básico, ou vários tipos de serviços (por exemplo, educação). Nem é óbvio o motivo pelo qual não deveria haver um crescimento da agricultura de consumo interno..." (Flanders 1964a: 315).

Jacob Viner, um crítico de primeira hora da CEPAL, vislumbra ainda uma outra possibilidade, igualmente desprezada no Estudio, qual seja, a de reduzir o excedente de mão-de-obra na agricultura (causa alegada da deterioração) pela redução da taxa de crescimento populacional (Viner 1951: 198) ${ }^{89}$.

\section{IV.12- Argumentos baseados na estrutura do real: Ligação de coexistência}

\footnotetext{
${ }^{88}$ V. seção IV.7 acima.

${ }^{89}$ Em artigo de 1970, Prebisch dá a entender que sua objeção ao controle populacional é de natureza religiosa (v. Cornejo 1972: 475-6).
} 
A ligação de coexistência, ao contrário dos outros argumentos citados, não faz parte do Estudio como uma criação de Prebisch, mas de seu auditório. A reflexão que este último faz a respeito do texto inclui uma das formas da ligação de coexistência, a interação orador-discurso. O que é inevitável quando o orador representa a Comissão Econômica para a América Latina e seu assunto declarado são os problemas inerentes ao desenvolvimento econômico desta região. Inevitável pensar que os partis-pris do orador contaminarão seu discurso.

Daí, pensamos nós, todo o esforço de Prebisch por construir um texto asséptico, eivado de dados numéricos e fatos históricos, onde os valores parecem não ter nenhuma influência, a não ser aqueles tão abstratos que contam com a total adesão da maioria dos auditórios, como o desenvolvimento ou a justiça. E é também para impedir uma interação orador-discurso que lhe é desfavorável que Prebisch apresenta julgamentos de valor como julgamentos de fato, afirma veementemente sua neutralidade, e usa da estratégia sinuosa de negar uma tese para fazer prevalecer outra (argumento de divisão).

Uma interação particular prejudicou a penetração do discurso cepalino na Argentina. Devido a suas atividades na década de $1930{ }^{90}$, Prebisch era ainda em 1949 considerado um representante dos interesses da elite rural argentina, e jogado na vala comum dos "reacionários", muito embora seu discurso já então fosse consistente com o discurso populista dominante em seu país, à época (V. Furtado 1985: 101).

\section{IV.13- Interação entre argumentos}

Um procedimento de interesse particular para nós é o uso de argumentos independentes que levam à mesma conclusão, o que Perelman qualifica de "interação por convergência", na qual o valor acordado à conclusão e a cada argumento isolado será aumentado, "pois parece pouco verossímil que vários argumentos inteiramente errôneos conduzam a um mesmo resultado" (Perelman 1958: 624). Além disto, temos de considerar que estamos num contexto argumentativo, não impositivo. Neste último caso, um só argumento, desde que formalmente válido, seria suficiente. Uma terceira razão para o uso de múltiplos argumentos é a heterogeneidade do auditório (Perelman 1958: 632). Dissemos, na seção IV.3, que o auditório da CEPAL pode ser, grosso modo, dividido em dois, um deles estando de antemão convencido da necessidade de industrialização, e outro, mais cético, tendente a seguir a visão clássica e endossar a divisão internacional do trabalho então vigente. A esta cisão do auditório corresponde uma heterogeneidade no texto, que inclui argumentos destinados a convencer a uns e a outros.

${ }^{90}$ V. seção II.4. 
Quase todo o Estudio é constituído por uma série de argumentos, de diversas naturezas, em favor da industrialização e do protecionismo. Seguem-se alguns exemplos de convergência de argumentos.

a) O argumento principal do Estudio reza que o excedente de população na agricultura da periferia permite que o aumento de produtividade deste setor redunde em redução de preços, enquanto o aumento de produtividade na indústria cêntrica é apropriado pelos proprietários de fatores de produção (devido aos elementos de monopólio e à existência de sindicatos fortes). Só a absorção do excedente populacional através do desenvolvimento da indústria estancaria a deterioração dos termos de troca. Este argumento é chamado por Rodriguez (1981: 60) de versão contábil do argumento da deterioração.

b) Outro argumento constitui, segundo Rodriguez, sua versão ciclo. Propomos aqui a hipótese de que se trata de um caso particular da interação entre argumentos por convergência, já que a versão ciclo é tautológica. Explicando: a versão ciclo, de corte keynesiano, consiste na observação do comportamento dos termos de troca durante o ciclo, de elevação na fase crescente (devido ao efeito do excesso de demanda agregada no centro sobre a demanda de matérias-primas) e de redução na fase decrescente (pela razão simétrica). A premissa (não explicitada no Estudio) que é relevante para gerar a tendência à deterioração é a de que o crescimento da renda per capita no centro é mais que proporcional ao aumento de produtividade, o que é logicamente equivalente à tendência à deterioração. Não se deve concluir daí, no entanto, que a versão ciclo seja retoricamente inútil. Sua completude lógica, aliada a sua verificabilidade (o comportamento dos termos de troca é efetivamente cíclico) só acrescenta ao poder de convencimento do argumento principal ${ }^{91}$.

c) Identificamos ainda um terceiro argumento relacionado à piora dos termos de troca, mas independente dos dois primeiros. O crescimento industrial estimula o setor primário, mas a recíproca não é verdadeira. Um aumento da produção primária (e da renda periférica) gera um aumento menos que proporcional na demanda (mundial) de produtos industriais e, consequentemente, um aumento menos que proporcional na renda do centro e na demanda cêntrica por produtos primários ${ }^{92}$. Como os termos de troca são função direta da demanda cêntrica por produtos primários e inversa da oferta destes mesmos produtos, conclui-se que os termos de troca pioram para a periferia (CEPAL 1950: 51-2).

d) Em outros pontos do texto (CEPAL 1950: 4; 50-1), a indústria é o único meio de absorver o excedente populacional, mas aqui sem nenhuma referência à deterioração.

\footnotetext{
${ }^{91}$ Assim se expressa Guzmán (1976: 256): "A introdução de considerações sobre as oscilações cíclicas só acrescenta um maior realismo à análise de Prebisch...".

${ }^{92}$ Esta última passagem, do aumento da demanda mundial de produtos industriais para o aumento da demanda cêntrica de produtos primários, não é explicitada no texto.
} 
e) A piora dos termos de troca e a redução do coeficiente de importação do centro, ao provocar déficits nos balanços de pagamentos dos países periféricos, obrigaramnos a reduzir seus próprios coeficientes de importação - supostamente, através da proteção alfandegária e substituição de importações (v. CEPAL 1950: 34; 41). Esta é a essência da argumentação de todo o capítulo II do Estudio. Este argumento se apóia na experiência histórica (fatos) e na presunção (comum a todos os economistas e mesmo ao público em geral) de racionalidade dos agentes econômicos. Assim, o protecionismo na periferia, se ocorreu historicamente, tem que ter uma explicação racional, a qual Prebisch procura prover.

f) Um argumento em tudo análogo ao anterior está nas referências de Prebisch à industrialização já ocorrida na América Latina (CEPAL 1950: 4; 14; 65).

g) A indústria na periferia é econômica mesmo que não melhore os termos de troca, porque utiliza mão-de-obra de outra forma desempregada - em outras palavras, seu custo alternativo é nulo (CEPAL 1950: 57).

h) A industrialização da periferia é inevitável: "Por la fuerza de las cosas, una proporción creciente de la población activa de la América Latina, como parte de la periferia del sistema, irá desplazándose desde la agricultura hacia la industria y buscando otras ocupaciones urbanas, conforme avanza el progreso técnico" (CEPAL 1950: 5 - grifo nosso; v. também pp. 13-15).

i) Argumento de justiça: assim como o centro procura defender seus setores menos competitivos em relação à periferia, esta recorre à proteção aduaneira para defender sua indústria da concorrência cêntrica (CEPAL 1950: cap. V).

Só num contexto retórico esta quantidade de argumentos é admissível, cada um deles aumentando o poder de persuasão do discurso. Ademais, da forma como são apresentados ao leitor, estes argumentos não parecem convergir de forma deliberada - o que, aliás, destruiria a impressão de neutralidade. A transição de um a outro é quase imperceptível, e em muitos deles a conclusão não é sequer enunciada. É isto que permite aos comentaristas, tanto favoráveis quanto desfavoráveis, se referir à "tese de Prebisch", ignorando sua diversidade. O que não impede a atuação da convergência dos argumentos, ainda que (e talvez porque) os leitores não tenham dela plena consciência. O valor industrialização é reforçado pelo fato da industrialização, incontestável por sua própria concretude, e por uma suposta necessidade lógica alçada ao nível de fato. O discurso normativo confunde-se com o que procura explicar a industrialização e a proteção alfandegária passadas.

Um ponto particularmente interessante é o de que praticamente o único argumento que atraiu a atenção dos críticos, na já vasta literatura sobre a CEPAL, foi o argumento principal, que envolve a deterioração. Propomos a hipótese de que os adversários acadêmicos da CEPAL - um público particular - só levaram em conta a parte da teoria que 
podia ser analisada segundo os cânones da metodologia modernista, que enfatiza a verificabilidade das teorias, ou sua correspondência com o "mundo real" ${ }^{3}$. Flanders (1964 a: 309) aventa uma outra explicação para a predominância deste argumento no debate: ele seria o que suscita a resposta mais emocional. A versão ciclo, apesar de aparentemente verificável (e verificada), não gerou polêmica por ser tautológica. Por isto toda a controvérsia ficou centrada em torno da questão de saber se houve ou não deterioração dos termos de troca, deslocando a discussão de seu eixo inicial - a necessidade de industrialização - e, segundo pensamos, permitindo que Prebisch prosseguisse a conquista de corações e mentes do público ao qual seu discurso efetivamente se endereçava. A reação dos críticos foi, em termos retóricos, inepta, porque não levou em conta as inclinações do auditório-alvo da CEPAL, mas a de um outro auditório, o acadêmico.

Foi tendo em vista este público acadêmico, que valoriza a concisão, a simplicidade formal, que Flanders (1964a: 321) pôde afirmar que a argumentação excessiva prejudicou Prebisch. De todo modo, deve-se observar que a extensão da argumentação tem um limite, além do qual reduz-se a persuasividade do discurso. Isto porque a interação entre argumentos, assim como pode reforçá-los, pode enfraquecê-los. Basta para isto que o leitor reaja negativamente a um deles, discordando de suas premissas, ou achando um erro lógico. A partir daí é possível que ele perceba a convergência dos argumentos como um procedimento "retórico", artificial. Ao fazê-lo, o leitor estaria praticando uma dissociação de noções (v. seção I.2), separando a argumentação "natural" da argumentação "retórica", o que desqualifica imediatamente esta última.

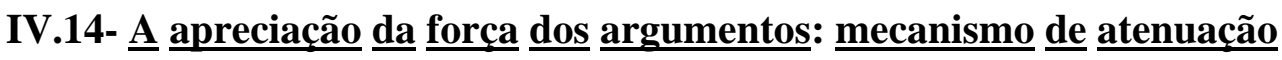

Na maior parte do texto, Prebisch, segundo o uso comum, superestima a força de seus próprios argumentos, tratando os argumentos quase-lógicos como se fossem silogismos incontestáveis; considerando sua metáfora seminal não como o que é, mas como um dado da realidade; fazendo uso de uma linguagem de convicção etc.

Em algumas passagens, no entanto, o procedimento é invertido, dando origem a um mecanismo de atenuação (v. Perelman 1958: 618-620). Este procedimento consiste em restringir voluntariamente o alcance de um argumento, em manter a conclusão aquém daquilo que o leitor poderia aceitar.

O argumento principal do Estudio, como vimos, parte das hipóteses de que o progresso técnico é mais intenso no setor exportador do centro que no da periferia e de que

${ }^{93}$ Observações semelhantes sobre a estreiteza dos interesses da crítica são feitas por Rodriguez (1981: 226) e Flanders (1964a: 305 e 309). 
todo o aumento de produtividade resulta em redução de preços, concluindo que os termos de troca deveriam melhorar para a periferia. Nestas condições, e usando a terminologia cepalina, a estabilidade dos termos de troca já seria um indicador de que parte dos frutos do progresso técnico da periferia estaria sendo transferida para o centro. No entanto, e aí entra o mecanismo de atenuação, os dados, tal como interpretados por Prebisch, indicavam uma piora dos termos de troca para a periferia. A conclusão de que há transferência dos frutos do progresso técnico da periferia para o centro é tida então pelo leitor como moderada, o que facilita sua aceitação.

Outro exemplo: Prebisch testemunha neutralidade e objetividade no debate quando afirma ter aberto mão de usar, como argumento em favor do protecionismo, as "circunstâncias excepcionais que conduziram à grande acumulação de ouro nos Estados Unidos durante os anos trinta, e também aquelas outras responsáveis por resultados análogos, nos últimos tempos" (CEPAL 1950: 42), considerando apenas os fatores persistentes de desequilíbrio - embora em outras partes do texto isto seja usado.

Um exemplo mais interessante é aquele em que a concessão é puramente nominal. "Desde otro punto de vista, la ingente cantidad de capital que sería necesaria, en estos países, para aumentar rapidamente la intensidade de aquél [...] plantearía problemas insolubles de transferencia al exterior." No parágrafo seguinte Prebisch explica que, sendo a maior parte dos bens de capital importados, haveria forte escassez de divisas. Ao que se segue a renúncia a argumentar por esta linha: "No es el caso de examinar ahora este aspecto monetario del problema de crecimiento y capitalización" (CEPAL 1950: 73 - grifo nosso). Ocorre que o essencial do argumento já foi exposto, e portanto não houve concessão efetiva. Além disto, como Prebisch aparentemente abriu mão de um argumento, reforça-se no leitor a impressão de que o orador confia na força dos argumentos remanescentes.

Tendo analisado extensivamente, neste capítulo, as principais características do Estudio do ponto de vista argumentativo, bem como seus procedimentos retóricos, só nos resta alinhavar, no próximo capítulo, as conclusões que emergem do trabalho até aqui desenvolvido, tanto no que diz respeito à teoria cepalina quanto ao discurso em geral. 


\section{V - Conclusão}

Procuramos, nos capítulos anteriores, demonstrar que o Estudio é um discurso argumentativo, que se desenvolve em função do auditório ao qual se dirige, e que, por este motivo, a análise retórica é de utilidade para sua compreensão. Retomamos agora, sucintamente, as partes mais relevantes de nosso trajeto.

Do segundo capítulo, que descreve o contexto histórico em que se insere a criação e difusão das teorias cepalinas, retenhamos três pontos fundamentais: o primeiro, de que estavam em curso nos países mais importantes da América Latina políticas econômicas francamente protecionistas e industrializantes, que tinham ampla, embora não irrestrita, aceitação; o segundo, de que vários economistas, como Wageman, Manoilesco, Colin Clark, Rosenstein-Rodan e Nurkse abordaram temas e mesmo utilizaram argumentos específicos que seriam depois retomados por Prebisch; o terceiro, de que foram propósitos de defesa dos interesses econômicos da região que motivaram a criação da CEPAL, propósitos estes que convergiram para o discurso industrialista e protecionista que caracterizaria a instituição, a partir da ascensão de Prebisch.

É preciso notar, portanto, que ao menos uma parte do auditório já estava predisposta a aceitar as prescrições cepalinas, o que facilitou o trabalho de convencimento. $\mathrm{O}$ mérito maior de Prebisch não foi tanto o de construir um edifício teórico absolutamente original e consistente, mas o de integrar idéias diversas sobre desenvolvimento que circulavam por esta época, de par com um vago anti-imperialismo, e dar-lhes uma formulação retoricamente eficiente. Tudo, em seus textos, converge para a defesa da industrialização, mesmo quando a aparência é de um texto isento, técnico, teórico. Prebisch envolve o leitor numa teia de argumentos de diversas naturezas, por vezes mostrando a inevitabilidade do protecionismo e da industrialização, outras vezes enfatizando a desejabilidade destas medidas, mas sempre tomando como ponto de partida as crenças e valores de seu auditório. O qual, por sua vez, não é o auditório universal, genérico, mas um auditório bastante específico, que podemos descrever, de forma simplificada, como sendo os próprios governos latino-americanos. Depreende-se da análise retórica do Estudio que Prebisch soube usar com maestria as características de seu público-alvo para persuadí-lo a agir da forma desejada. A par disto, a CEPAL inaugura uma nova forma de ver o fenômeno do subdesenvolvimento, o que pode ser verificado pela generalização do uso de sua metáfora "centro/periferia".

Tal metáfora, como dissemos no capítulo IV, funda a estrutura do real, ao propor que os países sejam classificados, para efeito de seu estudo no âmbito da teoria do desenvolvimento, conforme sua posição no comércio internacional, a saber, como exportadores de matérias-primas ou de produtos acabados. Toda a argumentação posterior 
reforça a idéia, já contida na metáfora, de que a periferia está, e estará sempre, a reboque da dinâmica cêntrica, até que desenvolva suficientemente seu próprio setor industrial, reduzindo sua dependência econômica dos países já industrializados. Uma segunda implicação desta estrutura do real é a de que, ao contrário do que ocorre na teoria econômica tradicional, os agentes de cada pólo do comércio internacional são tratados coletivamente. As ações, interesses e conflitos entre agentes econômicos da periferia só aparecem, e com pouco destaque, no nível do diagnóstico: desemprego entre os trabalhadores rurais, efeitodemonstração vigendo nas classes de altas rendas e reduzindo o nível de poupança global. As soluções preconizadas são macroeconômicas (industrialização, crescimento da produtividade e da renda) obliterando os conflitos de interesse internos.

Um segundo elemento argumentativo sobre o qual é construído o Estudio é o argumento quase-lógico de divisão: ao dividir os modelos de desenvolvimento possíveis para a periferia em dois - via exportações primárias e via desenvolvimento do mercado interno - a identificação dos problemas do primeiro modelo torna-se necessariamente uma defesa do segundo. Como Prebisch atribui a tais problemas o status de fatos (desemprego, deterioração dos termos de troca, déficits crônicos no balanço de pagamentos), a defesa do crescimento hacia adentro assume caráter compulsório, inquestionável. Assim, o que teoricamente se poderia definir como um julgamento de valor (a desejabilidade da industrialização) aparece, ao fim do argumento, como um julgamento de fato (a necessidade da industrialização).

Não poderia ficar de fora desta recapitulação o papel desempenhado pelos valores, muito especialmente pelo do desenvolvimento e o da justiça. Tais valores, amplamente aceitos pelo auditório, e disseminados por muitos dos argumentos do Estudio, permitem a comunhão entre orador e auditório, tornando-o mais receptivo à argumentação proposta e, portanto, a suas conclusões. Assim é que toda a ênfase é posta na iniquidade das relações comerciais internacionais, que explicam, em última análise, o fenômeno do subdesenvolvimento.

Um último ponto que compete salientar é a própria variedade da argumentação utilizada: argumentos quase-lógicos, os que "fundam a estrutura do real", recurso a fatos, presunções, valores, conjugados de diferentes formas e repetidos com sutis variações, tudo no texto converge para a defesa da industrialização e do protecionismo. Tal convergência não pode ser, evidentemente, fortuita: ela aponta, como vimos afirmando, para a natureza argumentativa do Estudio, como de resto de qualquer discurso não estritamente formalizado. Só no contexto argumentativo tem sentido se utilizar mais de um argumento com o mesmo fim, de forma a que eles se reforcem mutuamente ou, alternativamente, visem subauditórios específicos.

Verificando-se a história econômica da América Latina de 1949 para cá, não se pode deixar de reconhecer que Prebisch e a CEPAL venceram seu debate. Venceram-no no 
sentido de impor como incontestável a necessidade de acelerar a industrialização latinoamericana. E venceram-no com o concurso dos argumentos que viemos de citar.

Registramos, mais uma vez, que não pretendemos, apesar das observações críticas que fazemos sobre a argumentação do Estudio, acusar Prebisch de má-fé perante seus leitores. Fazê-lo seria retomar a tradição positivista, que pretende separar rigidamente fatos e valores, e relegar toda argumentação não-formal ao campo do engodo. O discurso (e o discurso cepalino não é exceção) envolve a transmissão de valores do orador para o auditório.

Como conclusão de ordem mais geral, gostaríamos de registrar a insuficiência da análise lógica para a compreensão do discurso científico, uma vez que aquela se ocupa exclusivamente das relações formais entre premissas e conclusões. Dois aspectos primordiais são deixados de fora: primeiro, os motivos pelos quais são escolhidas determinadas premissas, e não outras quaisquer, e segundo, as relações de ordem extra-lógica (ou não estritamente lógica) entre premissas e conclusões. Um exemplo paradigmático é o da metáfora. Frisamos que sua presença no discurso absolutamente não o desloca para o campo do irracional. Fosse esse o caso, quase todo, se não todo, o acervo de conhecimento atualmente tido como científico sofreria a mesma condenação. Insistimos no ponto: a argumentação não é um sucedâneo, de pior qualidade, da razão. É a mais importante, e mais largamente utilizada, de suas expressões.

Consequentemente, a análise retórica é um instrumento indispensável para desvendar as formas, infinitamente variadas, de que o orador-cientista se serve para transitar entre premissa e conclusão. Só uma tal análise, finalmente, permite, e até exige, uma leitura menos inocente, perfeitamente consciente do fato de que o discurso não é um objeto dado, independente, mas um meio de interação entre o orador e seu auditório, num jogo de mútuas influências. 


\section{Referências Bibliográficas}

Alba, Victor. Las ideas sociales contemporáneas en México. México: Fundo de Cultura Económica, 1960.

Albert O. Hirschman (org.). Controversia sobre latinoamérica. Buenos Aires: Editorial del Instituto, 1963.

Aldrighi, Dante M. e Salviano Jr., Cleofas. A grande arte: A retórica para McCloskey. In: Anais do XVIII Encontro Nacional de Economia, vol. 1, Brasília, 1990.

Almeida, Guido de. Linguagem e ação comunicativa. Belo Horizonte: UFMG (tese de doutorado), cap. 1.

Arida, Pérsio. A História do pensamento econômico como teoria e retórica. Mimeo, segunda versão, 1984.

Arndt, Heinz W. Economic development: The history of an idea. Chicago: The University of Chicago Press, 1987.

Arjo Klamer, Donald McCloskey e Robert Solow (eds.) The consequences of economic rhetoric. Cambridge: CUP, 1987.

Assael, Hector. El pensamiento de la CEPAL : un intento de evaluar algunas críticas. Trimestre Económico, LI (3), 1984.

Baer, Werner. The economics of Prebisch and ECLA. Economic Development and Cultural Change, X (2), 1962.

Baldwin, R. E. Secular movements in the terms of trade, American Economic Review, Papers and Proceedings, maio de 1955.

Barilli, Renato. Retórica. Lisboa: Editorial Presença, 1983. Rhétorique et culture, Revue Internationale de Philosophie, 127-128, 1979.

Beautell, Cristóbal L. RP: La renovación permanente de su pensamiento crítico. Comércio Exterior 37, (5), 1987.

Bhagwati, J. A skeptical note on the adverse secular trend in the terms of trade of the underdeveloped countries. Pakistan Economic Journal, 1960, dez.

Bianchi, Andrés. Notes on the theory of LA development. Social and Economic Studies, 22 (1), 1973.

Bicchieri, Cristina. Should a scientist abstain from metaphor? In A. Klamer, D. N. McCloskey e R. Solow (eds.) The consequences of economic rhetoric. Cambridge: CUP, 1988.

Bielchowsky, Ricardo. Pensamento econômico brasileiro: $\mathrm{O}$ ciclo ideológico do desenvolvimento.

Billig, Michael. Arguing and thinking. Cambridge: CUP, 1987.

Borel, M.- J. e Vignaux, G. Stratégies discursives et aspects logiques de l'argumentation. Langue Française, 12, 1971.

Buchanan, N. S. e Ellis, H. S. Approaches to economic development. Nova Yorque: 20th Century Fund, 1955.

Butos, William N. Rhetoric and rationality: A review essay of McCloskey's "The rhetoric of economics". Eastern Economic Journal, XII (3), 1987. 
Caldwell, B. e Coats, A. W. The rhetoric of economists: a comment on McCloskey. Journal of Economic Literature, ${ }^{\circ}$ 22, 1984.

Cardoso, Fernando H. La originalidad de la coopia: La CEPAL y la idea de desarrollo. Revista de la CEPAL, II (2), 1977.

Cornejo, Benjamin. The social doctrine in Prebisch's thought. In L. E. Di Marco (org.) International economics and development. Nova Yorque: Academic Press, 1972.

Diakosavvas, D. e Scandizzo, P. Trends in the terms of trade of primary commodities, 19001982: The controversy and its origins. Economic Development and Cultural Change, 39 (2), 1991.

Di Filippo, Armando. El deterioro de los términos de intercambio, treinta y cinco anos después. Pensamiento Iberoamericano, $\mathrm{n}^{\circ}$ 11, 1987.

Di Filippo, Armando. Las ideas de Prebisch sobre la economia mundial. Revista de la CEPAL, n 34, 1988.

- Raúl Prebisch: percepciones recientes sobre su vida y obra. Pensamiento Iberoamericano, 14, 1988.

Di Marco, L. E. (org.) International economics and development. Nova Yorque: Academic Press, 1972.

Dubois et alii. Rhétorique generale. Paris: Larousse, 1970.

Retórica da poesia. São Paulo: Cultrix/EDUSP, 1980.

Dyer, Alan W. Economic theory as an art form. Journal of Economic Issues, XXII (1), 1988.

Echavarria, José M. Consideraciones sociológicas sobre el desarrollo económico de América Latina. Buenos Aires: Solar/ Hachette, 1969.

Eco, Umberto. A estrutura ausente. São Paulo: Perspectiva, 1987.

Ellsworth, P.T. The terms of trade between primary producing and industrial countries, Interamerican Economic Affairs, X (1) 1956.

Economia Internacional. São Paulo: Atlas, 1978.

Figueiredo, Ferdinando. As transformações do pós-guerra e o pensamento econômico da CEPAL. Revista de Economia Política, X (4), 1990.

Flanders, J. Prebisch on proteccionism: an evaluation. Economic Journal, VXXIV (2), 1964a.

. The economics of Prebisch and ECLA: a comment. Economic Development and Cultural Change, XII (3), 1964b.

Frankenhoff, C. The Prebisch thesis: a theory of industrialism for Latin America. Journal of Interamerican Studies, IV (2), 1962.

Furtado, Celso. A fantasia organizada. Rio de Janeiro: Paz e Terra, 1985.

Gochet, Paul. L'Empire rhétorique: Rhétorique et argumentation, Revue Internationale de Philosophie, 127-128, 1979.

Gurrieri, Adolfo. La dimensión sociológica en la obra de Prebisch. Pensamiento Iberoamericano, 2, 1982.

Gurrieri, A. e Rodriguez, O. Desarrollo y democracia en el pensamiento de Raúl Prebisch. Comércio Exterior, 37 (5), 1987. 
Guzmán, Gabriel. El desarrollo latinoamericano y la CEPAL. Barcelona: Editoria Planeta, 1976.

Haberler, Gottfried. As relações de troca e o desenvolvimento econômico. In Howard S. Ellis (org.) Desenvolvimento econômico para a América Latina. Rio de Janeiro: Fundo de Cultura, 1964, 317-353.

Hirschman, Albert. Ideologias de desarrollo economico en América Latina. In A. O. Hirschman (org.) Monetarismo vs. Estruturalimo. Rio de Janeiro: Lidador, 1967. [1 ${ }^{\text {a }}$ edição 1961]

. The political economy of import-substituting industrialization in Latin America. Quarterly Journal of Economics, fevereiro de 1968.

Hodara, Joseph. Orígenes de la CEPAL. Comércio Exterior, 37 (5), 1987a.

. Prebisch y la CEPAL. México: Colégio de México, 1987.

Hopenhayn, Benjamin. Prebisch, pensador clasico y heterodoxo. Revista de la CEPAL, n 34, 1988.

Hyde, G. L. Examen crítico de la tesis de Prebisch. Revista de Economia Latinoamericana, III (4), 1963.

Ianni, Octavio. Estado e planejamento econômico no Brasil. Rio de Janeiro: Civilização Brasileira, 1986.

Jacques, Francis. Logique ou rhétorique de l'argumentation?, Revue Internationale de Philosophie, 127-128, 1979.

Johnson, Harry. The keynesian revolution and the monetarist counter-revolution, American Economic Review, LXI (2), 1971.

Kafka, Alexandre. Algunas reflexiones sobre la interpretación teórica del desarrollo económico latinoamericano. In H. S. Ellis (ed.) El desarrollo económico y América Latina. México: Fondo de Cultura Económica, 1960.

Kaldor, N. La estabilización de la relación de precios del intercambio en los países poco desarrollados. Boletín Económico de América Latina, VII (1), 1963

Kindleberger, C. The terms of trade and economic development. Review of Economics and Statistics XL (1) (supl.) 1958.

The terms of trade: A european case study. Nova Yorque: The Technology Press of MIT, 1956.

Koch, Ingedore G. V. Argumentação e linguagem. São Paulo: Cortez, 1974.

Klamer, Arjo. Conversas com economistas. São Paulo: Pioneira/ EDUSP, 1988.

Kluback, W. e Becker, M. The significance of Chaim Perelman's philosophy of rhetoric Revue Internationale de Philosophie, 127-128, 1979.

Latsis, Spiro. Introdução. In Spiro Latsis (org.) Method and appraisal in economics. Cambridge: CUP, 1976.

Lausberg, Heinrich. Elementos de retórica literária. Lisboa: Fundação Calouste Gulbenkian, 1966.

Lira, Maximo. La larga marcha de Prebisch hacia la crítica del capitalismo periférico. Trimestre Económico, LIII (3), 1986.

Love, Joseph L. Centro-periferia e troca desigual: Origens e crescimento de uma doutrina econômica. Revista Dados, 19, 1978. 
Raúl Prebisch and the origins of the doctrine of unequal exchange. Latin American

Research Review, XV (3), 1980. . Raúl Prebisch (1901-1986): Su vida y sus ideas.

Comércio Exterior, XXXVII (5), 1987.

Machlup, Fritz. Essays on economic semantics. Nova Iorque: W. W. Norton, 1967.

Maki, Uskali. How to combine rhetoric and realism in the methodology of economics. Economics and Philosophy, IV (1), 1988.

McCloskey, Donald. The rhetoric of economics. Journal of Economic Literature, 21, 1983. The rhetoric of economics. Madison: The University of Wisconsin Press, 1985.

Meier, Gerald. International trade and international inequality. Oxford Economic Papers, X (3), 1958.

Mirowski, Philip. Shall I compare thee to a Minkowski-Ricardo-Leontief-Metzler matrix of the Mosak-Hicks type?, Economics and Philosophy, III (1), 1987.

Molino, J. Métaphores, modeles et analogies dans les sciences. Langages, $\mathrm{n}^{\circ} 54$, junho de 1979.

Monteiro, João P. Teoria, retórica, ideologia. São Paulo: Ática, 1975.

Morgan, T. The long-run terms of trade between agriculture and manufacture. Economic Development and Cultural Change, VIII (1), 1959.

Myint, Hla. The gains from international trade and the backward countries. Review of Economic Studies, XXII (2), 1954-5.

La teoria económica y los países subdesarrollados. Revista de Economia Latinoamericana, $\mathrm{n}^{\circ}$ 12, 1963.

Nações Unidas. Conselho Econômico e Social. Las Naciones Unidas y la América Latina. Nova Yorque: Nações Unidas, 1962.

Nações Unidas. Departamento de Assuntos Econômicos. Relative prices of exports and imports of underdeveloped countries. Nova Yorque: Nações Unidas, 1949.

Nações Unidas. Comissão Econômica para a América Latina. Estudio Económico de América Latina - 1948. Santiago do Chile: Secretaria Geral, 1949. 1950.

Estudio Económico de América Latina - 1949. Santiago do Chile: Secretaria Geral,

Problemas teóricos y prácticos del crecimiento económico. Santiago do Chile: Secretaria Geral, 1952.

. El pensamiento de la CEPAL. Santiago do Chile: Universitária, 1969.

- En torno a las ideas de la CEPAL: desarrollo, industrialización y comercio exterior. Santiago do Chile: Secretaria Geral, 1977.

Development problems in Latin America. Austin: Texas University Press, 1970 (contém lista de publicações da CEPAL 1948- 1967).

. Raúl Prebisch: Un aporte al estudio de su pensamiento. Santiago do Chile: Secretaria Geral, 1987 (contém bibliografia completa de Prebisch).

Nurkse, Ragnar. A teoria do comércio internacional e a política de desenvolvimento. In Howard S. Ellis (org.) Desenvolvimento econômico para a América Latina. Rio de Janeiro: Fundo de Cultura, 1964, 271-316.

Parra-Pena, Isidro. El pensamiento económico latinoamericano. Bogotá: Plaza y Janés, 1984. 
Pazos, Felipe. Cinquenta años de pensamiento económico en la América Latina. Trimestre Económico, L (4), 1983.

Perelman, C. e Olbrechts-Tyteca, L. Traité de l'argumentation. Paris: PUF, 1958.

Rhétorique et philosophie. Paris: PUF, 1952, cap. 1.

Pinto, Aníbal. A CEPAL e o problema do progresso técnico. Estudos CEBRAP 18, 1976.

.Diagnóstico, estrutura e esquema de desenvolvimento na América Latina. In José

Serra (org.) América Latina: Ensaios de interpretação econômica. Rio de Janeiro: Paz e Terra, 1976.

Marginalización y dependencia de América Latina. In A. Prefácio a Castro, A. B. de e Lessa, C. Introdução a`economia.

Pinto, A. e Kñakal, J. América Latina y el cambio en la economia mundial. Lima: Instituto de Estudios Peruanos, 1973.

Pollock, D. US reactions to ECLÁs writings and activities. Santiago do Chile: CEPAL (mimeo), 1971.

Raúl Prebisch visto desde Washington: una percepción cambiante. Comércio Exterior, 37 (5), 1987.

Powelson, John. The strange persistence of the terms of trade. Interamerican Economic Affairs, XXX (4), 1977.

Prebisch, Raúl. El desarrollo económico de América Latina y algunos de sus principales problemas. Boletin Económico de América Latina, VIII, 1962 (primeira versão: segundo semestre de 1949).

Commercial policies in the underdeveloped countries. American Economic Review, XLIX (2), 1959.

Prefácio. In Rodríguez, Octávio. Teoria do subdesenvolvimento da CEPAL. Rio de Janeiro: Forense- Universitária, 1981.

Cinco etapas de mi pensamiento sobre el desarrollo. In CEPAL, Raúl Prebisch: Un aporte al estudio de su pensamiento. Santiago: Secretaria Geral, 1987.

Rappaport, Steven. Economic methodology: Rhetoric or epistemology?. Economics and Philosophy, IV (1).

A rejoinder to McCloskey. Economics and Philosophy, IV (1).

Rego, José M. Retórica e a crítica ao método científico na economia. In Anais do XVII Encontro Nacional de Economia, 1989.

Rodríguez, Octávio. Teoria do subdesenvolvimento da CEPAL. Rio de Janeiro: ForenseUniversitária, 1981.

Rogge, Benjamin. A tese de Prebisch. Estudos de Economia Teórica e Aplicada, $\mathbf{n}^{\mathbf{0}}$ 12, 1959.

Rorty, Richard. Philosophy and the mirror of nature. Princeton: Princeton University Press, 1979, cap. VII.

Rosemberg, Alexander. Economics is too important to be left to the rhetoricians. Economics and Philosophy, IV (1), 1988.

Rosenstein-Rodan, Paul. Problems of industrialization of Eastern and South-Eastern Europe. In: A. N. Agarwala e S. P. Singh (orgs.) La economia del subdesarrollo. Madri: Tecnos, 1963. 
Samuelson, Paul. International trade and the equalization of factor prices. The Economic Journal, LVIII (2), 1948.

Santa-Cruz, Hernán. La CEPAL, encarnación de una esperança de América Latina. Série Cuadernos de la CEPAL, n 50, 1985.

Sarkar, P. The Prebisch-Singer hypothesis: a statistical evaluation. Cambridge Journal of Economics, X (4), 1986.

Sebberson, David. The rhetoric of inquiry or the sofistry of the status quo? Journal of Economic Issues, XXIV (4), 1990.

Silveira, Antônio M. da. The public choice sedition: Variations on the theme of scientific warfare. In Anais do XVIII Encontro Nacional de Economia, Brasília, 1990.

Simonsen, Mário H. e Cysne, Rubens P. Macroeconomia. Rio de Janeiro: Ao Livro Técnico, 1989.

Simonsen, Roberto. A controvérsia do planejamento na economia brasileira. Rio de Janeiro: IPEA/ INPES, 1977.

Singer, Hans W. The distribution of gains between investing and borrowing countries. In B. Okun e R. Richardson (orgs.) Studies in economic development. Nova Yorque: Holt, 1961 [1 $1^{a}$ edição 1950].

. Tendencias recientes del pensamiento sobre los países subdesarrollados. Revista de Economia Latinoamericana, I (1), 1961.

Smith, Adam. Riqueza das nações. São Paulo: Abril, 1983.

Sodersten, Bo. Economia Internacional. Rio de Janeiro: Interciência, 1979, cap. 12.

Solís, Leopoldo. Raúl Prebisch en la CEPAL. Santiago: Centro Internacional para el Desarrollo Económico, 1989.

Spraos, John. The statistical debate on the net barter terms of trade. Economic Journal, XC (1), 1980.

- Inequalising trade?: A study of traditional north/south specialization in the context of terms of trade concepts. Oxford: Clarendon, 1983.

Streeten, Paul. Development perspectives. Londres: MacMillan, 1989, cap. 5.

Tavares, Maria da Conceição. Auge y declinación del processo de sustitución de importaciones en el Brasil. Boletin Económico de América Latina, IX, (1), 1964.

Toulmin, Stephen. The uses of argument. Cambridge: CUP, 1958.

Van Noorden, Sally. Rhetorical arguments in Aristotle and Perelman. Révue Internationale de Philosophie, 127-128, 1979.

Viner, Jacob. Comercio internacional y desarrollo económico. Madrid: Tecnos, 1961. (primeira versão: 1951).

. Seis conferências na Universidade Nacional. Revista Brasileira de Economia, junho de 1951.

Vuskovic Pedro. RP y su teoria del capitalismo periférico. Comércio Exterior, 37 (5), 1987. 